$\pi$

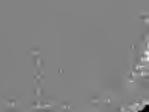

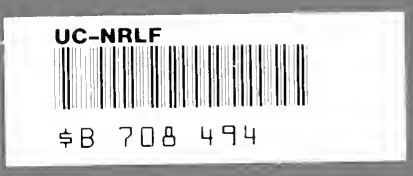

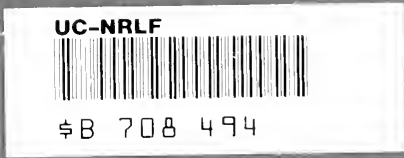

.

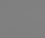

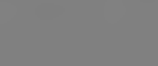

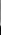

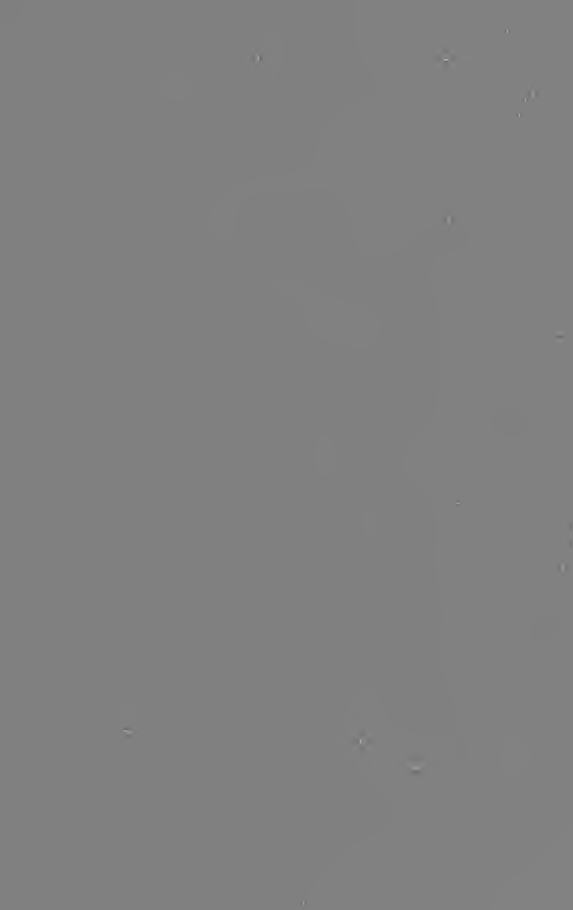$$
\text { क्ष }
$$$$
\begin{aligned}
& 3 \\
& 3
\end{aligned}
$$
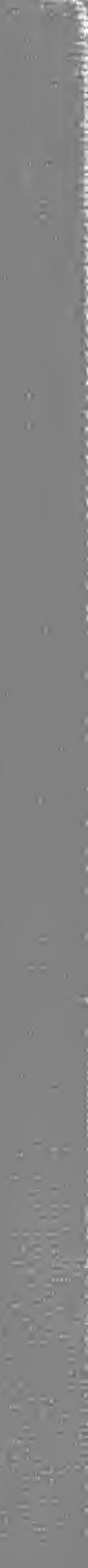


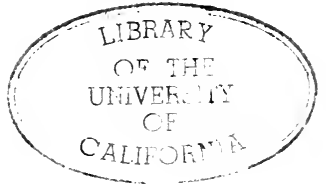




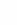

, 
Digitized by the Internet Archive in 2008 with funding from

Microsoft Corporation 
Comparative ethrographical

studies

4.

\section{THE COPPER AND BRONZE AGES IN SOUTH AMERICA}

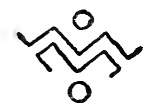

by

Gplard Mopdenskiöld

With Jwo Sippendives by Aivel Jlultigren 
CÖTLIORG 192I

IIIANIERS IBOKTRYCKIRI AKNIEBOI,A 


\section{jo}

\section{Oscar Mlontelins,}

in veruation and gratitude.

$-1)-2448$ 


$$
\text { - }
$$




\section{PREFACE.}

The publication of this solume has becn assisted by a grant from the sacdish Goiernment, to whom I beg to tender my respectiul thanks.

I hate also much pleasure in acknoweledging contributions from Baron Johan Mannerhcim and Mrs Ina rimitt toatards the arorking out of my material.

Professor G. Bodman has iery gencrously andertaken a number of analy'ses on my behalj, free of charge. Morecreer, a small grant which the Gothenburg Muscum obtained from the Municipal Council of Gothenburg for dealing with the collections has becn utilized for analy'ses, which have becn carricd out mainly by Dr G. Karl Almström. Mr.A. Hultgren has gratuituosly undertaken the metallographic cxaminations which acre carricd out at the Gothenburg laboratory of the "Secuska" Ball bearing Works (A. B. Secnska Lullagerfabriken), likewise without any charge being made. An account of these analyses is included in the present arort in the form of two appendixes.

The investigations that form the subject of this rolume are largel; based, apart from studics in the literature of the subject, on the copper and bronse objects, chicjly collected by the author himsell, housed at the (iothenburg Muscum (G.M.) and at the Riksmusect in sitockholm (H. M.). Cnpublished matevial in some "i the forcign muscums has also been utilized, after being a'cry kindly placed at the author's disposal. These musemms are: Hifuscum für Tölkcrkunde in Berlin (.I. I. V. B.), Muscum für Fölkcrkunde in Lcipsic, The Trocadero Muscum in Paris, The Linden Museum at stutterat, and 
Muscum für Völkerkunde in Vienna. The officials who hate becn of the greatest serice to me in these muscums, or hate placed at my disposal the desired material are: Dr Christian in I'icnna, Professor Dr Th. Koch-Grïnberg in Stuttgart, l)r F. Frause in Leipsic, I)r Paul Rivet in Paris, Professor I)r Max Schmidt in Berlin, Projessor Dr R. Verncau in Paris, and Professor Dr K. Weule in Leipsic. From the Museum iür Iölkcrkunde in Berlin I reccived, irec of charge, a considerable number of analy'ses undertaken by Professor I)r Ratgen.

The translation into English, from the Mss of the author and Mr Hultgren, has becn carricd out by I)r G. E. Fuhrken, I. A.

To all those who in one way or another have helped to defray the expenses of producing this work, or haie assisted we in it, I hereby oijor my sincerest thanks. Abore all I would thank. Mr Hultgren for the agrecable collaboration I hai'e enjoyed with him, and the Directors of the Sicnska Kullageriabrikcus S. K. F. for generously permitting the use of their laboratory for excuting the metallographic cxamination of the objects. 


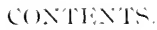

lintroluctio.1

Copper Objects that were in Cse, arcording to Jiarlier Authors. in the Iinpire of the Incas at the Time of the spanish conquest

objects of Copper reproduced on l'ottery. Textiles and ()ther 'Things

Copper Objects of which the Age can be determined from the Circunstances of the Find

International and I,ocal Types

Typology

Copper and Bronze Ages.

Why lin was mixed with the copper

The standardization of Bronze in Ine Tines

Where ware the Copper and Tin ()res obtained and where were

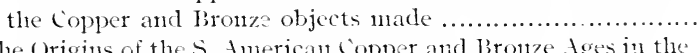

The origins of the s. Anerican Copper and Bronze Ages in the

$\therefore$ American Stone Age

The Bron\%e Age in the (Jhd World and in the New.

Iist of Objects Analyser

Appendix A

Appendix B

Bibliograplyy. 


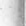




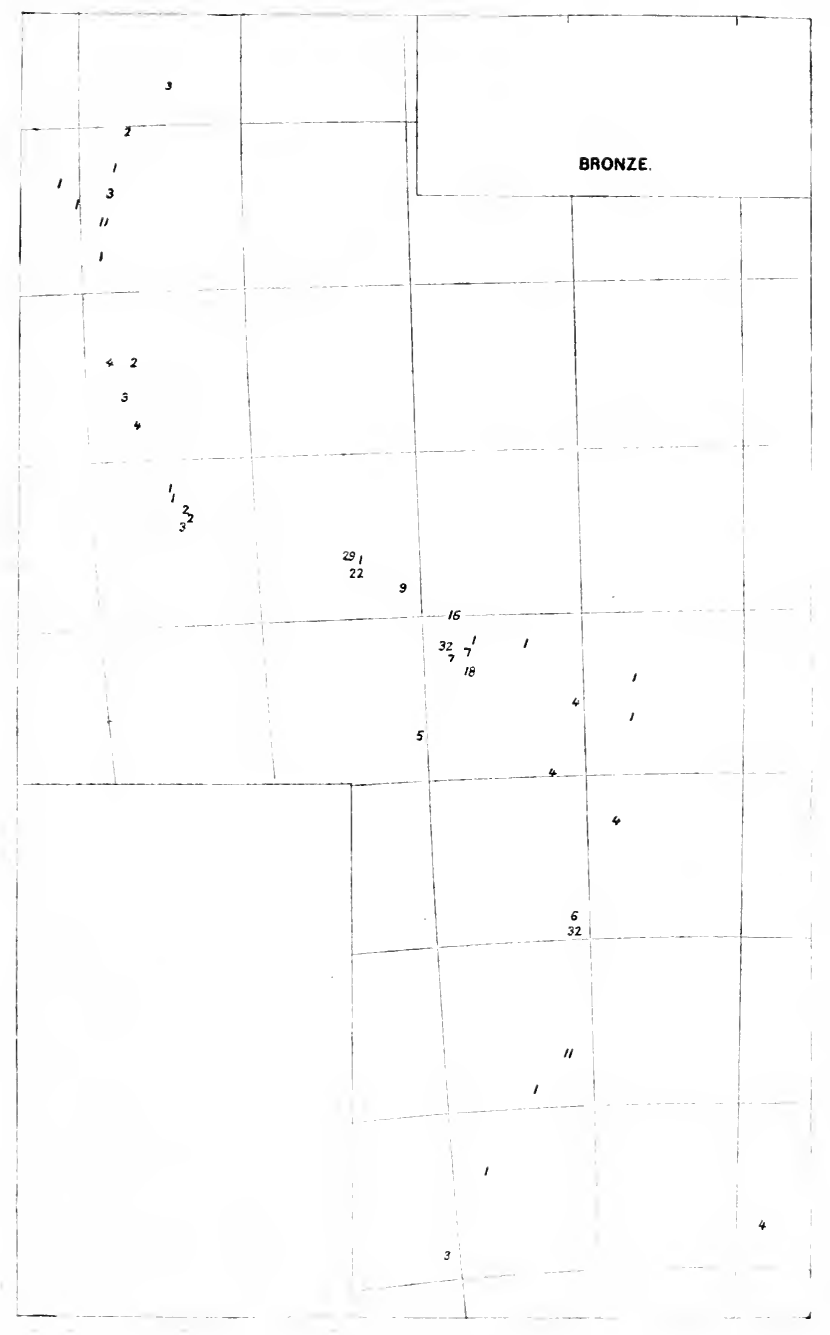


эรทоคม

c

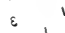

11

I

5 :

$s^{i}$

10

is 5

5

e

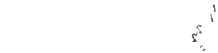

.

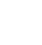




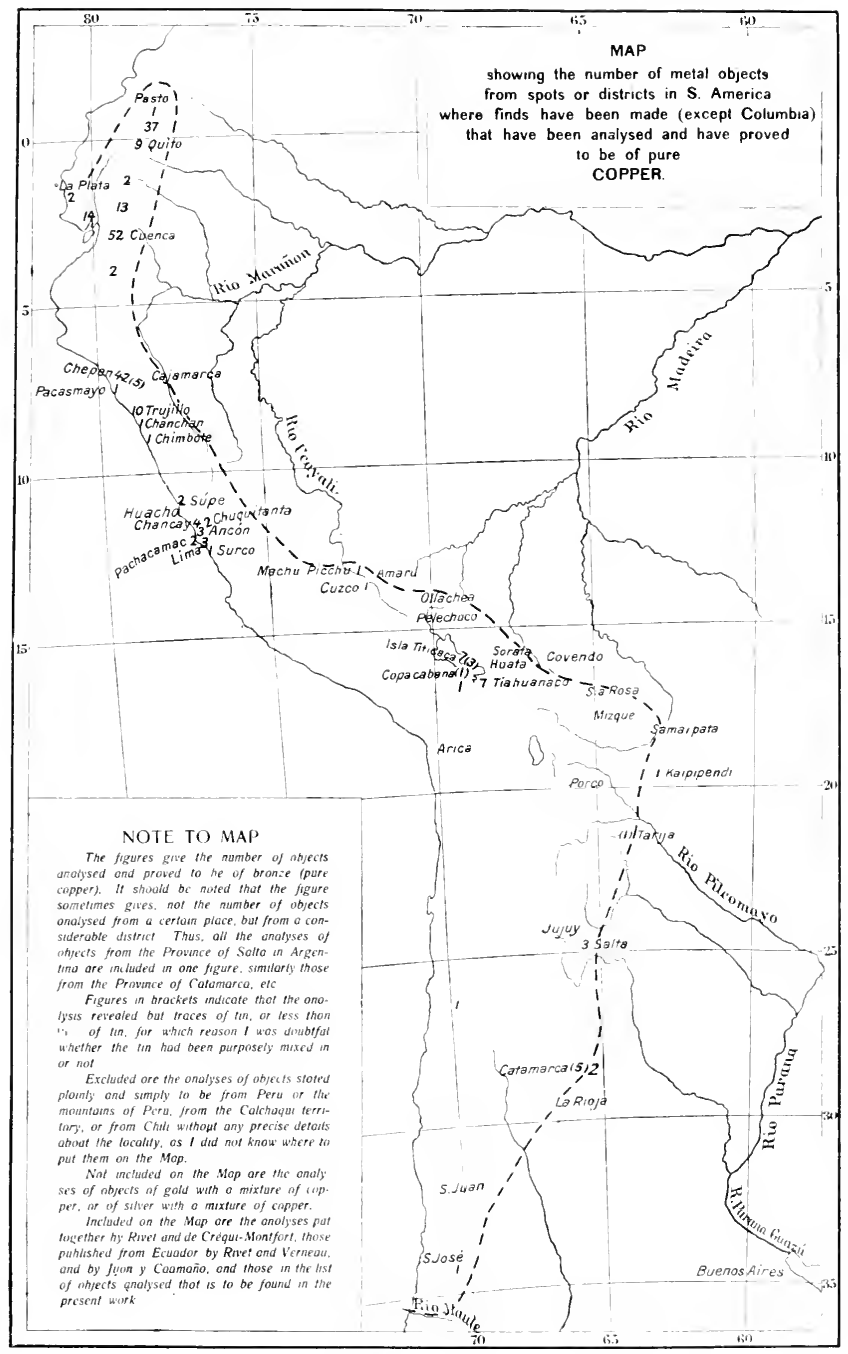

Map $\quad$. 


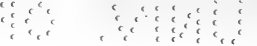

\begin{tabular}{c}
$\therefore$ \\
\hdashline \\
\hdashline
\end{tabular} 


\section{INTRODUCTION。}

If we study the literature of copper ${ }^{1}$ ) objects found in S. America, we shall find scattered intimations that certain types of objects must be more recent than others, and particularly the suggestion that the Bronze Age in s. America was preceded by a Copper Age. As early an authority as EwBank held that the Bronze Age in the west of S. America was preceded by a Copper Age. He was of opinion that it was unreasonable to suppose that the Indians should have continued to make tools of pure copper after becoming accuainted with bronze. My fellow-countryman ERIC Bontax assumes that the bronze objects found on the Peruvian coast are Incan, and thus of a more recent period than the objects of pure copper. RIViT and VERxEAr have shown that the Bronze Age in Ecuador was evidently preceded by a Copper Age. 'They consicler that bronze was first introduced into Eicuador by the Incan conquest of the country.

An intinate study of the copper objects found in s. America with a view to their relative chronology has, however, not been made. 'This is what I have attempted, and it is the results of these studies that I have put together in the following pages. In studying the cop-

1) When I do not know whether an object is of copper or of bronze, I call it copper. If it has leeen analysed, I call it pure copper when it has been proved to contain no tin, and bronze when it contains tin. What I here call pure copper may therefore contin antinony, arsenic, leal, etc., but no tin. Irill readers kindly bear this in mind throughent the present work. 
per objects found in S. America, I have therefore tried throughout to keep in mind the factor of timc.

In the first place I have brought together such statements from the old literature as deal with copper objects from the time of the Conquest. This will give us an insight into what was in use among the Indians at the beginning of the I6th century.

Metal weapons and the like are occasionally depicted on pottery and textiles. Thanks to these pictures we can see that certain of them must be contemporaneous with certain types of vessels and woven fabrics about whose relative chronology we have some knowledge.

Next I have compared the types of copper objects found under such circumstances as will enable us to draw some conclusions as to their age.

Relying mainly on RIVET and VerneAu's work I have attempted to distinguish forms of copper objects with a more local distribution from those with an extensive distribution, assuming, as will be seen, that the latter are usually from a later time than the former.

As far as possible I have also sought to utilize the typological method in order to be able to follow the development of different forms of copper objects.

Furthermore I have collected all the known analyses of copper objects from the west of S. America, with the exception of Columbia, after DE CrÉQUi-MIONTFORT and RIVET, and Jijón y CaAmaño, and have had a considerable number of objects analysed, in order to determine what forms are of purc copper and which of bronic. I have tried to prove that throughout the whole territory of the old Inca Empire the Bronze Age was preceded by a Copper Age.

1. We shall see that the various methods that have been employed do not, broadly speaking, yield contradictory results, and that the conclusions I have reached by one method are confirmed by another. 
Even as late as I9I2 Jorck, in his handbook on the archaeology of S. America, gave it as his opinion ${ }^{1}$ ) that the Indians of S. America had not purposely alloyed copper and tin. He bases this assertion on the fact, to which attention was drawn by MorTILLET and Bomin, that the tools often contain less tin than the ornaments, though the former required more hardness than the latter. But that tin was intentionally added in the S. American bronzes, in spite of this apparent inconsistency, has been shown by both the American, MEAD, and, especially, his fellow-countryman, the metallurgist Mathewson. The fact is that we must not regard the American bronzes from quite the same points of view as we are accustomed to adopt when we are concerned with the bronzes of the Old World. With this problem I have also been occupied in the following pages, and, as I have already mentioned in the preface, have been greatly assisted in this respect by Mr A. HulTgrex.

The relationship between the Copper and Bronze Ages in the Old World and the New is of course a problem of the greatest interest. But it must be treated with considerable care, for a thorough discussion of it must be preceded by a systematic study of the development in America of the pure copper and bronze forms, as well as that of the relationship of the American Copper and Bronze Ages to the American Stone Age. This problem too, I shall touch on in the following.

After these introductory remarks I will attempt to develop in detail the points of view I have to present.

1) P. 210. "It seems almost certain that the presence of tin is accidental, since it is found in greater quantities in those implements which require it least." See also the footnote, $i b$. p. 132. 


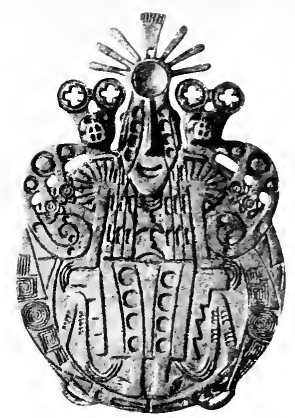

Fig. I. Copper-disk from Catamarca, Argentina. (After Posiaxski. (I)) $1 / 4$.

\section{CHAPTER I.}

Copper Objects that were in Use, according to Earlier Authors, in the Empire of the Incas at the Time of the Spanish Conquest.

In the early literature that has been accessible to me, a number of copper weapons and implements are mentioned, but the statements about them generally tell us very little. The authors of these works took far more interest, of course, in objects of gold and silver than in those of the less valuable copper. Of importance are the statements that are sufficiently detailed for us to be able to recognise forms that we meet with in the archaeological excavations, and can therefore verify that they were in use at the beginning of the I6th century.

Several of these anthors mention copper clubs. ${ }^{1}$ ) The reference is evidently to clubs with star-sliaped club-heads.

1) See, for instance, Risaciones (imográficas, Vol. II, pp. I4, is, $22,25,32,45$. I.AS CASAS, P. I 94. 
'This appears, for instance, from Xrisiz's account of the capture of Atahualya. $\left.{ }^{1}\right)$ He says that the club-heads had five or six points. Coppes and stone club-heads of this kind have been found pretty generally throughout the territory of the Inca Eimpire. (See Fig. 22). As a rule they have six points, but those with five are not rare. CoBo $^{2}$ ) says that the club-heads used by the Indians in the Inca Iimpire were of copper.

Copper axes were evidently a weapon that was in conmon use in the Inca Empire at the time of the Concuest. ${ }^{3}$ ) It is mentioned from Cuenca in Ecuador ${ }^{-1}$ ) that such axes had been introduced after the Inca conquest. XerEz ${ }^{5}$ ) likens them to halberds. Сово ${ }^{6}$ ) says they were of copper or stone. The princes had axes of gold and silver.

LAS $\operatorname{CASAS}^{7}$ ) also speaks of little axes that were in use in the Incan Empire; the haft was "T'res palmos" in length, and they were provided with a kind of sword-knot to prevent their being dropped during a fight.

GARCILASSO $^{8}$ ) mentions axes among the Incan tokens of honour. The axe shown in Fig. 2 B, C from Cuzco seems to

1) P. 99... "la porra que está al cabo engastonada es de metal, tan grande como el puño, con cinco ó seis puntas agudas, tan gruesa cada punta como el dedo pulgar." See also Oriedo y VALDES, Lib. XLVI. Cap. VIII, Vol. IV, p. I77. and Huamax Poma, p. $5 \mathrm{I}_{4}$.

2) Cово, p. 196

3) Reidaciones GFográficas, Vol. II, p. 45 (Collaguas), p. 240 (Sanct Miguel de Piura), Vol. III, p. I9o, p. I93, (Cuenca) p. 2 I 7 (Loxa).

4) RELACiONES GEOGŔ́ficas. Vol. III. p. I93. "Peleaban con porrillas, defendiendo sus tierras y pertenencias.... Despues del IxGUA lian tenido lanzas de palma... hachuelas de cobre."

5) P. Iоo. "Las hachas son del mesmo tamaño y mayores; la cuchilla de metal de anchor de un palmo, como alabarda."

$\left.{ }^{6}\right)$ P. I96. "Las hachas de arma tenian el hierro ó cuchilla de cobre ó pedernal."

7) P. I94. ${ }^{8}$ ) Lib. VI, Cap. XXVII. "Por ultima divisa real davan al Principe una hacha de armas que llaman Champi, con una asta de mas de una braça en largo. Ėl hierro tenía una cuchilla de la una parte, y una punta de diamante de la otra, que para ser partesana no le faltaba mas que la püta que la partesana tiene por delante". 
me to fit in best with Garcilasso's description. He calls this axe Champi, a word which is employed in the oldest literature for very dissimilar things. ${ }^{1}$ )

The Araucanians had axes of copper at the time of the Conquest and had also lances with points of copper. ${ }^{2}$ ) Bolas balls of copper are mentioned in RELAciones GEOGRÁFICAS ${ }^{3}$ ) from Collaguas. Similar ones of various types are common discoveries round L. Titicaca.

It is of the greatest interest to find in the oldest literature descriptions of the type of knife commonly found throughout the old territory of the Incan Empire, and which, in modern archaeological works is quite correctly called $T u$ mi. Knives of this kind are shown in Fig. 2I. AmbrosetrTr ${ }^{4}$ ) considered that it was this type of knife that MonTesinos ${ }^{5}$ ) had in mind when he wrote, "Tumi es un instrumento de cobre de la hechura de trinchete de zapatero, que se ensartaba en un palo". Bertonio, ${ }^{6}$ ) too, compares the Indian Tumiknife to a shoemaker's knife when he explains the meaning of the word tumi in his famous Aymara Lexicon. In Ay-

1) CoBo (p. 196) calls the clubs with star-shaped heads Champi. HUAMax Poma (p. 5I t) calls them Chanbi (Champi) or guaman Chanbi (huaman Champi). BeRTONio, in his Aymara Lexicon, translates Champi by 'partesana, an offensive weapon, and 'hacha' an axe. In HoLGuin's Lexicon under Champi we find. "Maça o porra de armas" and in the Lexicon edited by Ricardo Champi is porra para pelear. Saxcto Thomas translates Chambi with porra para aporrear. MIDDENDORF, in his Quichua Lexicon, translates Champi by 'metal; mezcla de oro y cobre', and also by 'arma de indios, especie de clava con hacha'. Huamax Poma also designates as Chanbi a lance ornamented with a hem of feathers along its shaft.

2) OYARzÚx (Cites Iovera etc.).

3) Vol. II, p. 45. "Peleaban con unas mazas de palo recio y fuerte, y para que lo fuera mas, aforrábanlas con plata ó cobre tirado y al cabo una porra, de plata ó de hierro (a) con unas puntas, é con hondas é lachas de cobre, é con unas cuerdas de niervos recias y al cabo puestas unas bolas de cobre pesadas, tiribanlas, llaman á éstas ayllos, y hoy lo usan en sus cazas y unonterias."
4) (1) P. 203 .
5) P. 15.3 .
$\left.{ }^{6}\right)$ 'Tumi Cuchillo de los indios al modo de aquel que usan losçapateros. 
maran tumi was also probably a knife in general. Thus, European knives, too, were called tumi. According to Holguin, ${ }^{1}$ ) tumi in Quichuan was an Indian knife of copper without a handle, sliaped like an axe. This, is after all, a very good definition of this type of knife. ${ }^{2}$ )

With such knives "Inga Huira Cocha", according to Montesinos 3 , had 8,000 prisoners beheaded. In the picture, Fig. 3I, we can see how a knife of this kind was evidently used for beheading. The earthen vessel from which this figure is taken, is considered by $\left.\mathrm{UHLE}^{4}\right)$ to be much older than the Inca period. As we sliall see, the shape of the tumi is typologically older than the tumi-knives that were presumably in use during the Inca period. BAL$\mathrm{BOA}^{5}$ ) relates how Mama-Guaco killed another Indian with a tumi or stone knife. CIEZA DE LEON ${ }^{-6}$ also mentions knives of copper and stone, used on the coast of Ecuador for beheading human victims.

The older literature, as we have seen, throws some light on the metal weapons used in the Inca Empire. Of implements - apart from the tumi knife - we do not get to know much. Garcirasso mentions a curious kind of primitive hammer of copper and "laton". This was really

1) 'tumi - cuchillo de indios de cobre a manera de segur sin cabo.'

2) WIENER's designation, 'tulpo', must apparently be registered annong the mistakes his work contains.

3) P. 154. "los presos dicen los indios que pasaron de ocho mil. Otro dia, despues de la victoria, 11andó el Inga Huira Cocha pasarlos todos à cuchillo; y no paró en ésto porque mandó buscar los viejos y las viejas de aquella provincia, y los lizo cortar las cabezas. I por esto llamaron á este lugar Tumibamba."

4) (3).

5) P. 15.

6) P. 402. (Vedia) "Con sus navajas de pedernal ó de cobre el sacerdote mayor dellos lo mataba, y cortándole la cabeza, la ofrecian con el cuerpo al maldito demonio, enemigo de natura hmmana". It is presumably similar scenes of sacrifice that we find reproduced on a number of earthen ressels from the Peruvian coast. 

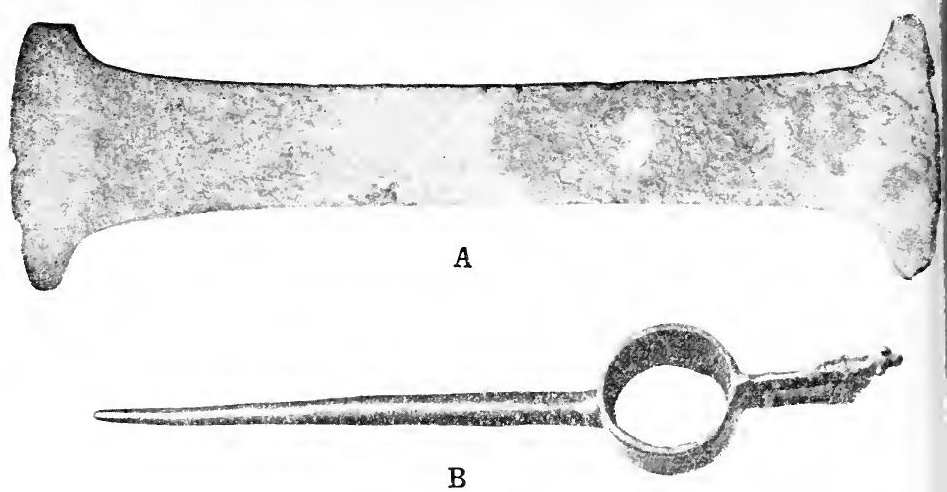

B

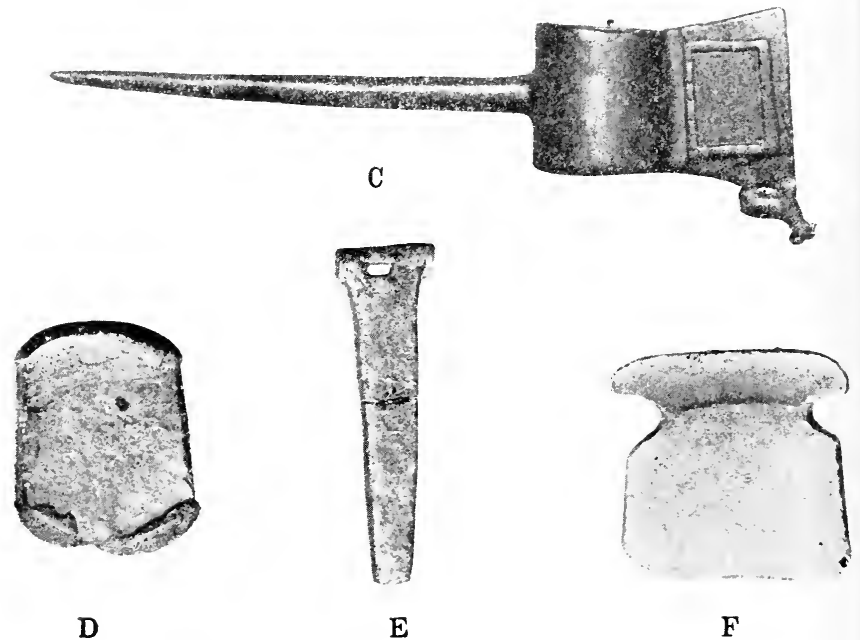

Iigs 2 A-2I: Copper objects from Argentina, Bolivia and P'eru. Nearly ${ }^{1 / 2}$ The originals in the Museun für Völkerkunde in Berlin. $A=$ Cranp. Andalgala, Sta Maria, Argentina. (Catalogue 110. V. A. 4057). B, C-Weapon. (Cat. no. V. A. 8738). D. Hammer of the type described by Garcilasso DE LA Viag, Salta, Argentina. (Cat. nö. V. C. 5701). I - Bar of bronze in shape of axe. Onnasuyu, Bolivia (Cat. no. I. A. 12672 1.). I:- Axe, Salta, Argentina (Cat. no. V. C. 6385 ). 
only a lump of metal without a haft. ${ }^{1}$ ) A similar one (Fig. 2 I)) from Salta is to be seen at the Ethnological Inseu11n in Berlin. Gircinasso speaks furthermore of axes, "açuclas" and "escardillas" of copper and brass (açotar). He gives us no details about the shape of these. Garcilasso enumerates a number of implements not possessed by the Incas. Anong them lie mentions metal needles; ${ }^{2}$ ) but this must be wrong, for a quantity of them have been found in the Inca territory, and it is scarcely credible that they had gone out of use by the time of the Conquest. ${ }^{3}$ ) According to Garcinasso, there were only needles of 1)lant-spines. $\left.{ }^{4}\right)$

GARCILASSO ${ }^{5}$ ) mentions that the Incas had a kind of blow-pipe of copper, which they used in smelting metal. These were still in use in Garchisso's time. A picture of Pernvian Indians blowing at these pipes is given by BExzonI. ${ }^{6}$ ) The interesting picture is reproduced here. 'Two similar blow-pipes are to be seen, according to $\left.\operatorname{MEAD}^{7}\right)$, in the collections of the American Museim of Natural History.

1) "No supieron hazer martillos con cabo de palo, labravan con unos instrumentos que hazen de cobre $y$ laton mezclado uno con otro. Son de forma de dado, las esquinas miertas, unos son grandes quanto pueden abarcar con la mano para los golpes mayores, otros ay medianos, y otros chicos, y otros perlogados para martillar en concavo, traen aquellos sus martillos en la mano para golpear con ellos como si fueran quijarros». Libro II. Cap. XxiIII.

2) Libro II, Cap. XXVIII.

3) They are fonnd in graves from Inca times.

4) These trave also been found in graves from Inca times.

5) "fundian a poder de soplos con unos cañutos de cobre largos de nnedia braça mas, o menos como era la fundicion grande, o chica. Los cañutos cerrauan por el un cabo, dexananle un agujero pequeño, por do el ayre saliessa mas recogido, y mas rezio: juntauanse ocho, diez y doze, como eran menester para la fundicion: andaua al derredor del fuego, soplando con los cañutos, y oy se estan en lo mismo, que no ha querido nudar costumbre. Libro II, Capitulo XXVIII.

6) P. $25 \mathrm{I}$.

i) P. 43 . 


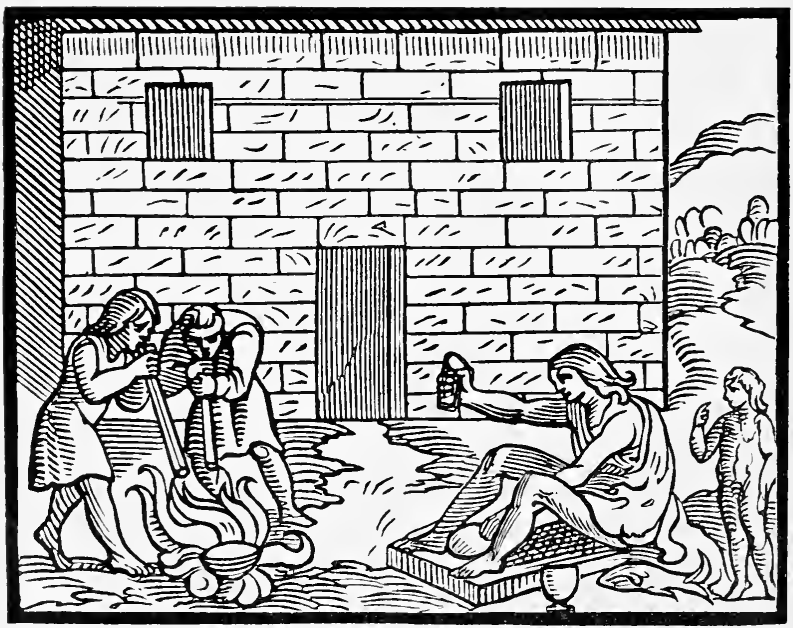

Fig. 3. Indian smiths in Peru from the middle of the I6th century. Two are using blow-pipes, the third a haftless hammer. (After Bexzoxi). 
spades and hoes of copper are mentioned by CoBo. $\left.{ }^{1}\right)$ The hoe referred to by Сово, to judge from his description, was probably of the type we see in Fig. $56 \mathrm{c}$, which is still used by the Quichua Indians, thongh with an iron blade. In the tracts bordering on the Inca Empire there were also agricultural implements of metal, as is clear from the stories that NUFlo DE Chaves heard from Indians near the Rio Paragnay, who had stolen some in the fields of the mountain Indians. ${ }^{2}$ )

Copper ornaments are scarcely mentioned at all in the older literature. More interest was, of course, taken in those of gold and silver. Shawl-pins ("topus») are mentioned in several places in the Reiaciones Geográficas. ${ }^{3}$ ) I have only twice seen it stated ${ }^{4}$ ) that they were of copper. The

1) Cobo. lome IV, p. 190. "Fuera desta suerte de arados tenían otro instrumento de an palo corvo, que hacia forma de hazuela de carpintero () de almoeafre, con que quebrantaban los terrones, escardaban y mullian la tierra; y estos dos instrumentos eran los principales con que labraban los campos. I'ara escardar los sembrados y hacer los hoyos en que enterraban el Maiz al sembrado, usaban de Lampas, que los mexicanos llaman Coas, $y$ es un instrunento conı azada, salvo que el lierro era de cobre, Y 110 corvo, sino llano conto pala corta de horno;"

2) Reiacionis Geogrificas, Tome II, p. LXXXVil. "Y que donde habian entrado era algunas casas que tenian en las chácaras, de noche, $y$ "que siempre hallaban palas y herramientas de metal."

() n the Rio Paraguay they knew all about the different kinds of metal used in the Inca Empire, as can be gathered from the following extract taken fron the sane souree as the preceding (p. LXXXIII.)

"I que cuanto á lo del metal, dijeron que era una cosa que tenian como hachas para cortar, salvo que nuo era blaneo y relucia mucho, y otro era anarillo. I'uéles mostrada una sortija de oro, la cual tomaron y le lieron con ella en los dedos y la ponian en las narices, y dijeron que de aquel era el metal anarillo. I'reguntado que para qué lo olian, dijeron 'tue porque habia otro metal anarillo que no era bueno y que tenía mal olor, y que de esto hacen en aquella tierra las herranientas con que cortan y hacen sus labores."

3) Tome I, p. 173 (Atunsoro), p. 189 (Atunrucana,) p 208 (Antanarcas).

4) Tome 1. P. I 49 (Vileas Guanan) "... y en los hombres se los prenden con unos alfileres de plata grandes y el renate ancho y redondo $y$ algunos son de cobre, los cuales llanan topos... T. III, p. II I. (O)tavalo). 
description of the form tallies with the type of topu we see depicted in Fig. 22 e, and which seems to have had a very wide distribution throughout the Inca territories. It is stated that topus were first introduced into Otavalo in Ecuador by the Incas. ${ }^{1}$ )

Nirrors of silver and of 'açofar', i. e. brass, are mentioned by Garcilasso. ${ }^{2}$ ) A bronze object that was probably a mirror of this sort, is illustrated and described by BAESSLER. $\left.{ }^{3}\right)$

I have not come across any description of how the Indians mixed tin and copper to make bronze. As a rule we are not enlightened as to whether the weapons and other things mentioned were of pure copper or of bronze.

Garcilasso, as we have seen, speaks of 'laton' and 'açofar', i. e. brass, though of course he means bronze, since brass was certainly unknown in S. America before the Discovery.

In Bertonio's Aymara Lexicon bronze is mentioned. Is a yauri and hanko yauri are rendered by "bronce o cobre muy duro." Yauri is copper. Hanko yauri means white copper. I do not know the meaning of $i$ sa, but according to BERTONIO the Aymara called steel yauri isaco or yaurina isacopa, whereas iron is only called yauri or quellaya yauri. According to the same authority, the Aymara called tin kausi, titi or chaantaca. ('T. I, p. 370).

Very mysterious is this entry in Bertonio's Lexicon:"Quisuthà yaurithà vlltatha qsu-es otra especie de cobre, que serutia a los indios como a nosotros el azero para que mezclado con otro sea mas fuerte». ${ }^{4}$ ) Was this bronze with a high percentage of tin, which was alloyed with copper? The Spanish quotation means: This is another kind of copper,

1) Reraciones Geográficas, Tome iII, p. iri.

2) "Los espejos en que se miravan las mugeres de la sangre real eran de plata muy bruñida y las comunes en açofar." Libro II, Cap. XxírII.

3) (I) I. 79, I.ig. 300 .

4) T. II, p. 395 . 
which served the Indians as steel with us, as mixed with other (copper) it became stronger.

Anta is Quichuan for copper. Puca anta is, according to Holguix, pure copper, titi is lead and yurac titi or chay anta is tin. The same authority says that in Quichuan bronze is chacrusca anta or hichhascca anta, and anta curi or anta çapa is gold mixed (with copper). According to MIDDENDORF, who had access to a number of older Quichua lexicons, which are unfortunately not in the Swedish libraries, puca anta is pure copper, ch'umpi anta bronze, chajruska anta alloyed metal, mich'uska anta alloyed copper, and 'hich'aska anta cast copper. According to v. Tschud, anta is Quichuan for metal generally, especially copper, puc'a anta for unalloyed red copper, chacrusca anta or hichasca anta for brass, bronze, or bell-metal, antacori for gold alloyed witl copper.

Within all the area of S. America where bronze was used, tin ore (cassiterite) only occurs in Bolivia and Argentina in any quantities. BARBA $A^{1}$ ) has already supplied a detailed account of the occurrence of tin ores in these parts. He mentions the tin mines at Carabuco near I. Titicaca, which, he says, were worked already in Inca times. BARBA, whose

1) Fol. 32. "No son ordinarios doude quiera los minerales de estaño, pero no se echan menos en aquestas riquissimas Prouincias. Famoso es A assiento de Collquiri, no lexos de la Coilla de san Felipe de Austria de Oruro, por el mucho, y muy bueno que de sus minas se ha sacado, y se saca para todo aqueste Reyno, entre cuyos, metales, como ya queda aduertido, se hallan a rezes ricas bolsas de metal de plata. Iunto a Chayanta, en los Cliarcas, ay otro mineral de estaño, de que se saca en abund ancia de algtnos años a esta parte. No lexos de Carabuco, una de los pueblos que cercan la orilla de la grandiosa laguna de Chnenyto, hazia la vāda de la Prouincia de. Larecaja, ay tambien labores deste netal, que los Indios trabajaron en tiempo de sus Ingas, y despues han proseguido los Españoles. Son las retas caudalosas, y ricos los metales en su genero, sacanse tambicn。entre thlos algunos de mucha plata, y todos participan de algun cobre, por cuya mezcla es este estano mas ristoso y duro. La fama de la riqueza destas vetas me lleno a verlas, demas de la curiosidal que he tenido ch ver, y experinentar los minerales de todas estas Prouincias." 
wide knowledge of the presence of minerals in these parts was based on a personal experience of many years, must be regarded as an extremely reliable author. In the University I,ibrary of Uppsala there is one copy of this very rare work.

BARBA also mentions a number of copper mines. ${ }^{1}$ ) Of those in Cerro de Scapi, two leagues from Chuyca in Lipes, those on the heights of Tarabuco in Chichas, and those sitwated near Curaguara in Pacajes, he says that they were worked by Indians in old times.

BARBA also mentions and describes the ovens ("huairas") in which the Indians smelted the ore. They are also described by several other old authors. ${ }^{2}$ )

Thus we see that in the older literature there is mention of the following implements and weapons of copper in use at the time of the conquest of the Inca Empire: tumiknives, axes, hoes, spades, hammers, star-shaped club-heads, and the bolas. Besides these there were blow-pipes, shaw1pins, and mirrors of copper. At least one tin mine that was worked as early as Incan times is spoken of, as well as some copper mines. We have detailed descriptions of the ovens in which the metals were smelted.

1) Fol. 29.

2) As Bomax (1) gives exhaustive quotations from the old literature about Huaivas, I would refer readers to his work. 


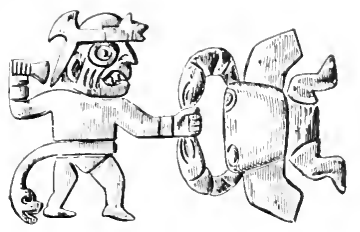

Fig. 4. Demon and crab, on a vase from Climbote. (After BAFSSI.ER 2) IFig. 330$) .1 / 4$.

\section{CHAPTER II.}

\section{Objects of Copper reproduced on Pottery, Textiles, and Other Things.}

In the foregoing chapter I put together the information I could gather from the older literature about the copper implements, weapons and ornaments used by the Indians. The Indians themselves have also something to relate about these things. I refer to the scenes in their life that are reproduced in their ceramic and other arts. In endeavouring here to study the Copper and Bronze Ages of the Indians, I will not onit to utilize this source of knowledge as well.

When we come across a weapon or implement reproduced on an earthen vessel or a woven fabric, we cannot, of course, say if it represents an object of bronze or pure copper. We do not always know even if it was an object of stone or metal that is reproduced. This does not stand in the way of our being able to deduct, by means of a careful study of the object depicted on the vessel or fabric, some information that may be of value with regard to the relative chronology of the copper or bronze object in question.

URTEAGA ${ }^{1}$ ) has drawings of a couple of Nazca vessels representing demons with axes in their hands. What shape

1) Figs. 4 and 5 . 


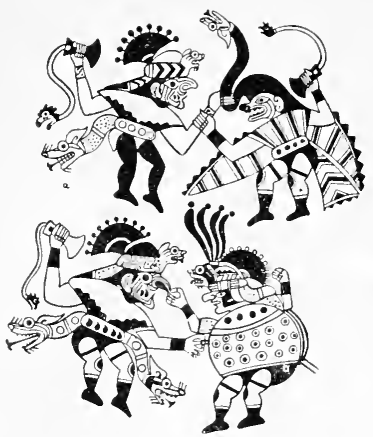

a

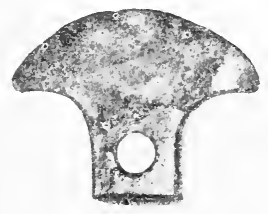

d

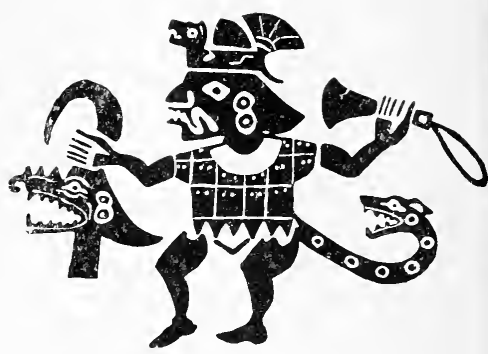

b

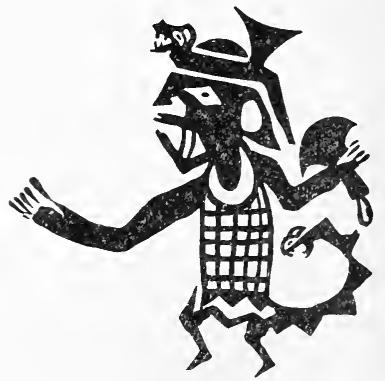

c

Figs 5 a $-5 \mathrm{~d}$.

a. Dennons fighting, painting on a vase from Trujillo. (After Jorcs, fig. IO).

b. Demon with axe in one hand and a decapitated demon head in the other. Painting on a vase from the coast of Peru. (Original in the Linden museun at Stuttgart. Cat. no. L. I $+50 / 97) .{ }^{1 / 3}$.

c. Demon rescmbling the former. Painting on a vase from Chicanna. (see Fig. 17). (Cat. 110. G. MI. 20, 9. 3I). 1/3

d. Axe from Inga-pirca, Iicuator. Of the type the demons seen to have usel. (After RIVIT and VERNIAL). ${ }^{1 / 4}$ 
these axes had originally, is difficult to conceive, since the Nazca artists evidently changed the same for decorative 1) urposes. As no axes have been found with Nazca pottery, we do not know of what material the axes reproduced were made. It is not altogether excluded, thongh scarcely likely, that they were of stone'). (Fig. 9, I)

Curious axes with a little hole in the narrow part at the back of the axe have been found pretty generally in Iicuador. (Fig. 5d). These axes are either of stone or of copper. On numerous earthen vessels found in N. Per $1^{2}$ ) demon figures can be seen with similar axes in their hands. This has already been pointed out by Boman and Joyce. ${ }^{3}$ ) From these pictures we can see that the hole in the axes served for fastening a piece of string into it which was presumably used for a loop round the wrist, to prevent the unhafted axe or blade from being easily dropped. ${ }^{4}$ ) That this axe was used unhafted, is thus clear.

1) From Nazca UnLE mentions but a single object of metal (gold). He writes: "Of metal objects produced by this civilization $I$ have, so far, only secured one single specimen, a piece of hammered gold, having an interesting mythological design upon it; it is now in the museum of the University of California. Doubtless implenents of metal must have existed and been used by these people, as one may infer from the painted designs upon the pottery when they are occasionally represented, but they are not preserved in these burials of such a very ancient date". Linfe (5) P. II.

2) B.AESSLer (2).

JorCe, p. 127. Demon with axes.

SELER (I) Pl. 20, 2I, 22. Demons with axes.

SQLIER (I) p. 226. Demon with axe.

Hayr Pl. XI. Damons with axes. (See also BEUChat p. 68I.) 3) (I) P. 230; P. 212.

4) The hole and loop in a number of Tumi-knives evidently served the same purpose. (Fig. 2I, a, d.) Knives carried in the same way as these axes, are mentioned by CABRERA (Relaciones Geográficas, T. II, p. 140), from the Juries: "y todos los más con un cuchillo colgado con un fiador de la mano derecha, que se proveen los inás dellos, o otras cosas que de hierro tienen de rescate." 


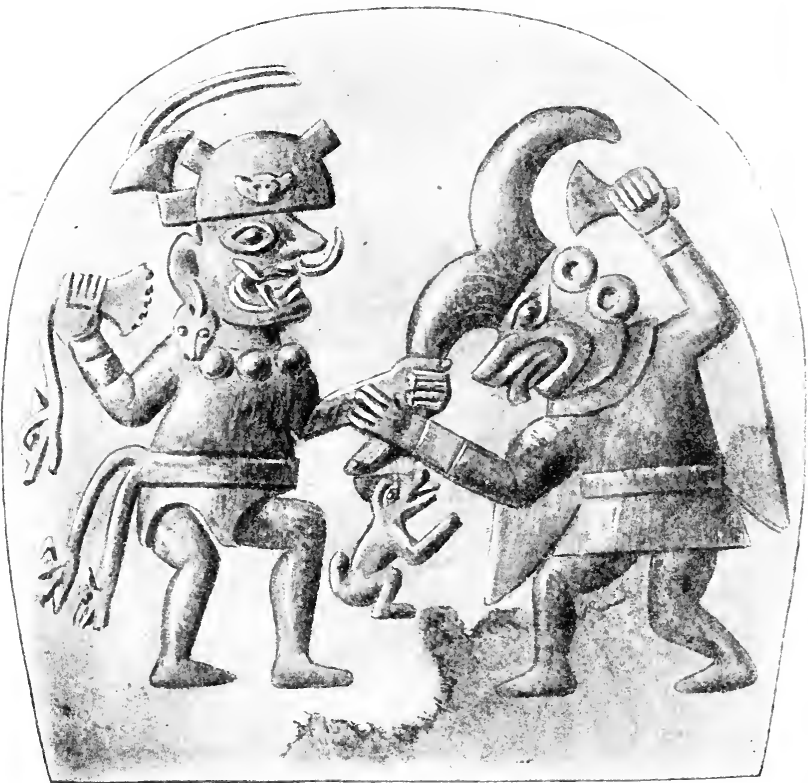

a

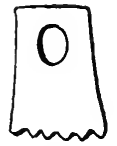

b

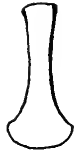

c

Fig. 6 a. Demons fighting; on a vase from Chimbote. (After BAESSI.ER (2) fig. 332 b.). The weapon of the one is an axe like that in Fig. 1); the other seems to have a tumi in his land. ${ }^{2}{ }_{3}$ 6 b. Copper axe from Cuenca, Eicuador. (After Jorce fig. 5 a 6 c. Tumi from the Peruvian coast. $1 / 10$. 
The axes in the different pictures vary somewhat, due partly to their being of somewhat different shape, partly, as is evident, to their being more or less inartistically and carelessly modeled or drawn. Sometimes the axe which the demon holds in his hand, appears to be toothed (Fig. 6). A toothed copper axe of this kind found at Cuenca in Ecuador, is reproduced by Joyce. ${ }^{1}$ )

From the pictures on the vessels we cannot, of course, say with certainty what material the axes that the demons are holding, were made of, but to judge from the sharplybent out edges I should say they were of metal, presumably. copper. That this type of axe, with a little hole in the haft, has not been found in the coast districts of Peru, although we find it generally reproduced on earthen ressels, may possibly be bound up with the circumstance that during the period when these axes were used, very few of the valuable copper implements were placed in the graves. The demoniacal head-hunters, armed with axes, may also represent some equatorial tribe that used to make inroads into the coastal districts of Peru, for, as we have already mentioned, this type of axe is commonly found in Ecuador.

On some of the ressels (Fig. 8) the demons seem to be holding 'Tumi-knives rather than axes $\left.{ }^{2}\right)$. Sometimes it is impossible to decide whether the weapon depicted is meant to represent an axe or a Tumi-knife. As a rule these Tumiknives seem to be of a typologically primitive type (see p. 68 ) and are not provided with a sword-knot.

On the vessel in Fig. 6 we can see two demons fighting with each other, one of them armed with an axe with its hole and sword-knot, the other with a weapon that looks very much like a 'Tumi of primitive type. It has no hole, and consequently no sword-knot.

1) Fig. 5 a.

$\left.{ }^{2}\right)$ It would perhaps be more correct to call these axes knives, as they are always without hafts. 

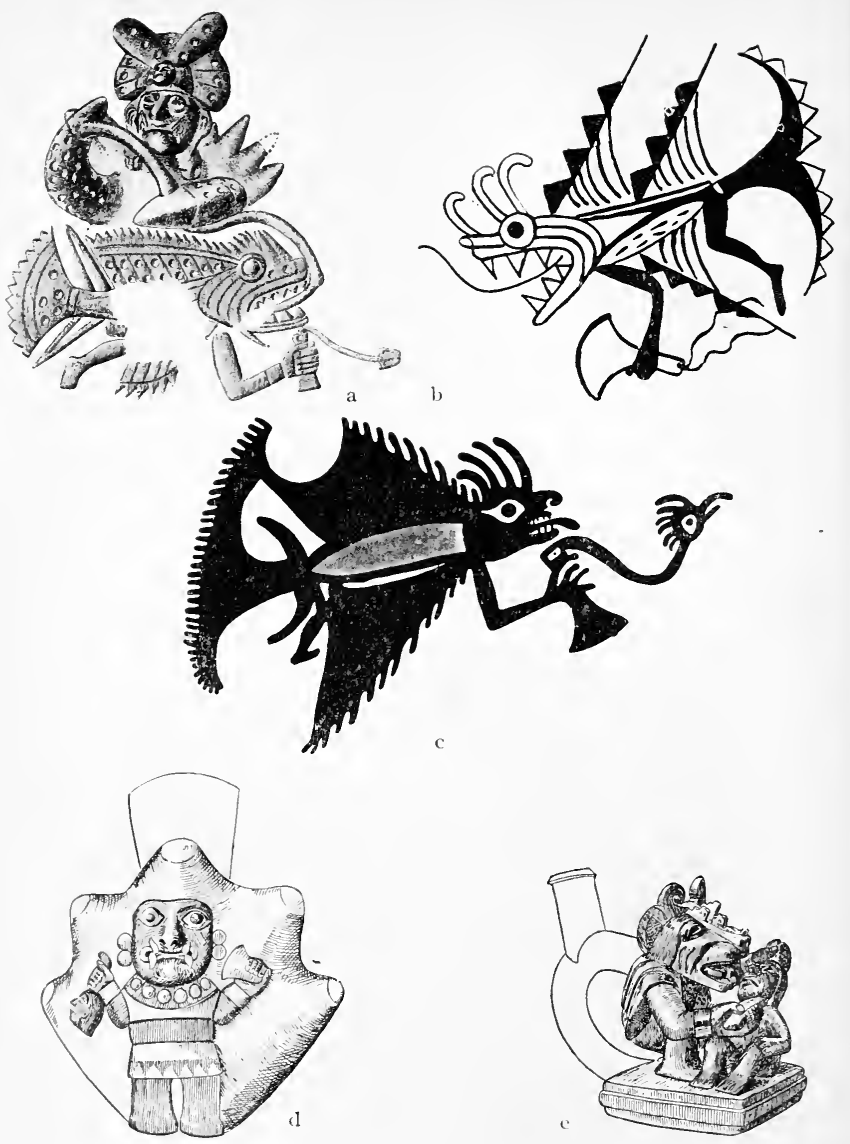

Iiigs. 7 a-e.

a. Dennon with big corner teeth catching a fish demon. Modeled on a vase from Trujillo. (After BAESSLER (2) fig. 338.). $1 / 5$.

1). Fishdemon painted on a vase from Chimbote. (After BAESSLER (2) fig. 327$) \cdot 4 / 15$

c. Iishdemon painted on a rase from Chicana. (Cat. no. G. M. 20. 9. 37). $1 / 3$

d. Vase from Chimbote representing a demon holding an axe in one hand and a decapitated human head it the other. (After BAESSLER (2) fig. 284$) \cdot 3 / 16$

e. Denon decapitating a nan. Vase from Trujillo. (After B.AEssLER (2) fig. 285$) .1 / 3$. 

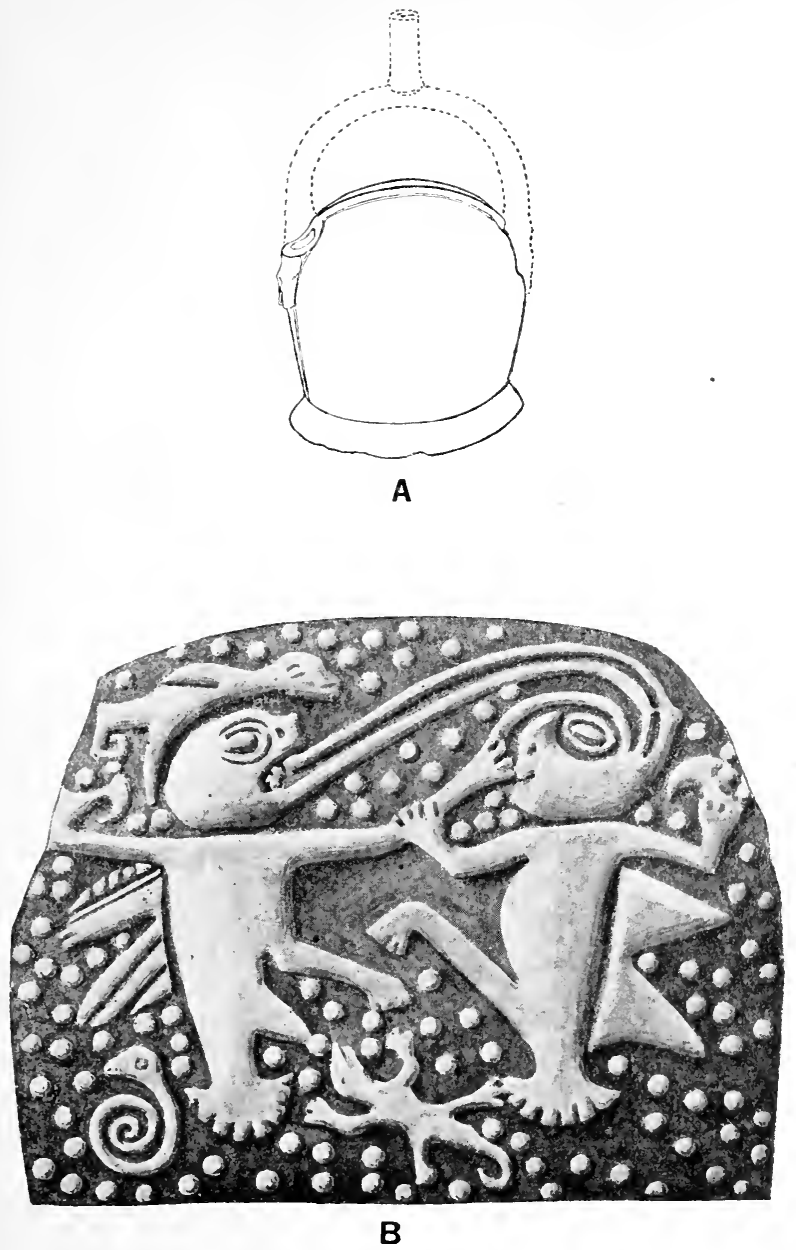

Fig. 8. Vase from Ferrenafe on the Peruvian Coast. (Cat. 11o. C. M. 20. 9. 89). A shows the shape, $B$ the ornamentation on one sille. The other side is almost identical. $\mathrm{B}-2 / 3$. 


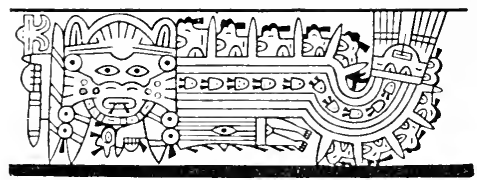

1.

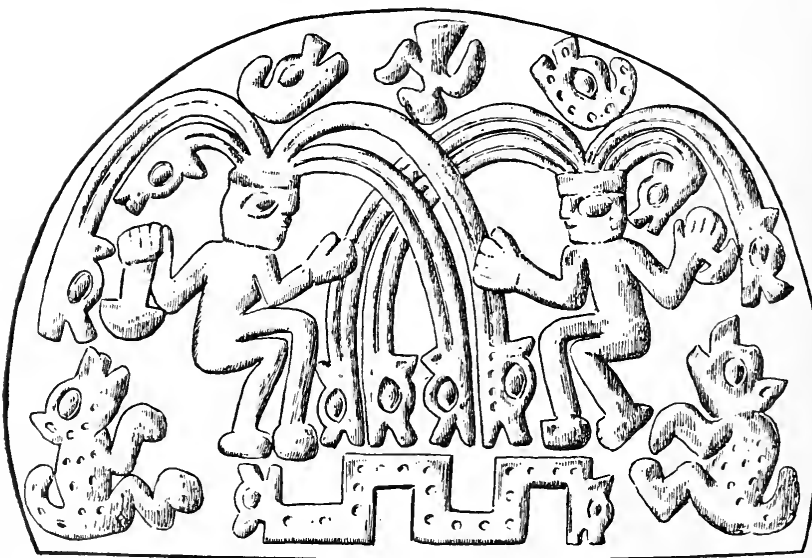

2.

Fig. 9. I. Painting on a drinking ressel from Nazca. The demon holds a hafted axe in his hand. (After URTEAGA).

2. Relief on a vase from Chimbote. (After BAEssler (2) fig. $278) .1 / 2$. 
If we look a little closer at these demons, the one on the left, with his big corner teeth and his head-gear with a little animal's head in front and a triangular adorninent behind, resembles several of the demons we see on the other pictures (Figs. 5 b, c), and who generally have axes in their hands. The demon on the right has quite a different headgear. He is very much like a demon that we can see pictured in Fig. $3 \mathrm{I}$ f. He has the same long nose, the same hanging-out tongue, and the same double circles at the ears. He also seems to be armed in the same way, with a 'Tumiknife of primitive type without a sword-knot.

The fish-demons always have axes with sword-knots. Earthen vessels with similar demons seem to be very common in collections from the north coast of Peru. (Fig. 7 . $a, b, c)$.

All these earthen vessels on which are depicted demons with axes or Tumis of a prinitive type in their hands, are to be ascribed, to judge from UHLE's investigations, to a very early period. He not only considers them to be preIncan, but even pre-'Tiahnanacan. The type of axe reproduced on the jars should therefore be very old. This is confirmed by its never being found on Incan pottery. 'The axes of this type that have been analysed, have proved, with the exception of two, which were of bronze, to be of pure copper. (See p. 77). This typologically primitive type of Tumiknife is not to be found on Incan pottery, either.

On a couple of earthen vessels (Fig. \&, and lig 9,2) the 'Tumiknives have a strongly bent ont edge, and a comparatively narrow handle. The figures on this ressel are but poorly modeled. They are possibly of a somewhat later period than the others, and may be copied from an older, more artistic pottery. Nor have these 'Tumi-knives sword-knots.

BAESSLER reproduces an earthen ressel from Pachamac (Fig. Io), representing a man holding a Tumi-knife. 
24

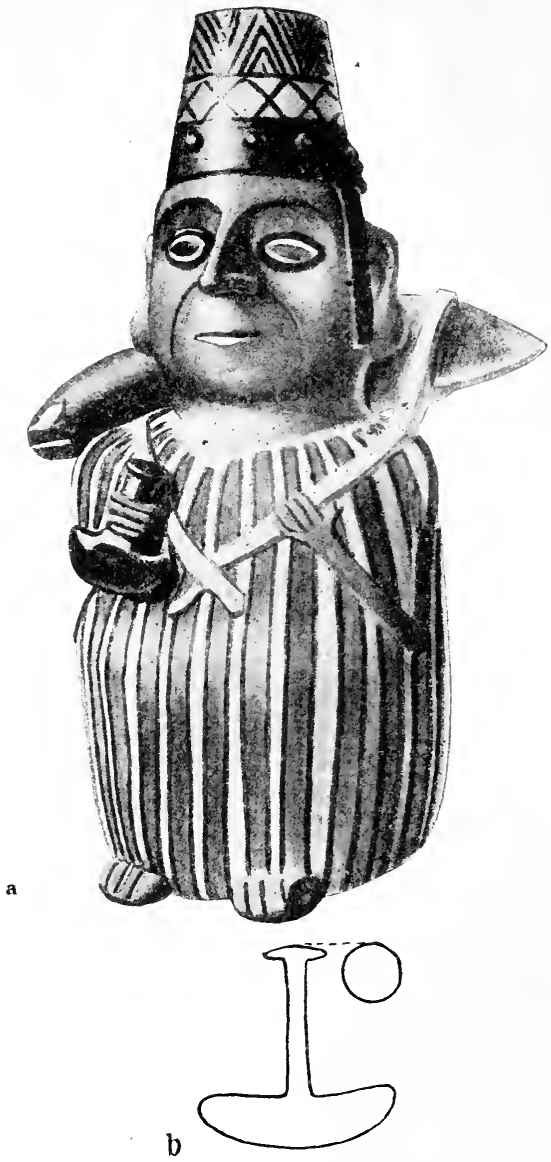

I*ig. Io. Vase from Pachacamac representing a man holding a Tumi like the one in the small fig. (b). As is still customary in the mountain districts of Peru, he is carrying something on his back with a rope fastened over his breast, not round his forehead. (After BAESSLER (2), I*ig. 423). ${ }^{1} / 2$. 


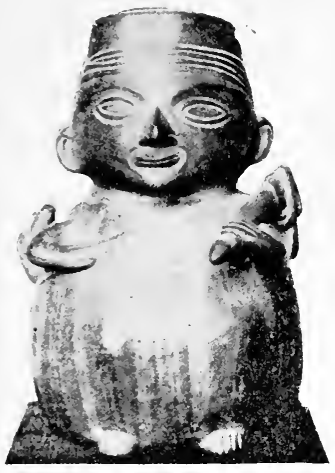

a

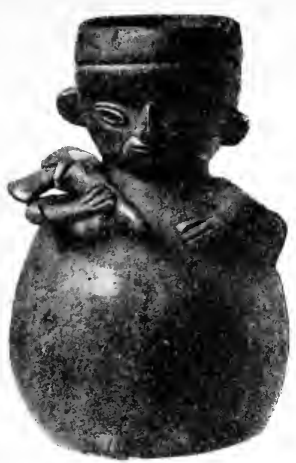

b

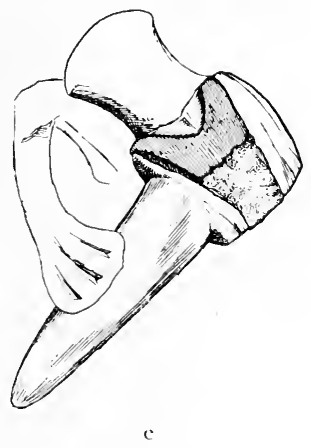

Figs. Ir a-I I c.

Figs. II. a. Vase from Tarma representing a person with a T-slaped axe in his hand. (After HAMY Pl. XXXIV). (Original height $0.20 \mathrm{~m}$ ).

b. Vase from Ancon like the foregoing. (Original in the Museum für Völkerkunde in Leipzig). (S. Am. 9988). (Original height $0.20 \mathrm{~cm}$ ).

c. Detail from b. 
The knife is so well modeled that it is not only evidently a Tumi-knife, but one with a handle that ends in a little round disk. This type of Tumi had a wide distribution. Thus, similar ones of copper are known from Chuquitanta on the coast of Peru, ${ }^{1}$ ) from the highlands of Bolivia ${ }^{2}$ ) and from Argentina ${ }^{3}$ ). BAESSLER ${ }^{4}$ ) reproduces another earthen vesse1 from the same place, representing a person carrying on his back a vase of undoubtedly Incan type (a so-called arybal1us). The ressel, which represents the man with the Tumiknife, and the one representing the water carrier, are of such similar types that they should be about of the same period, i. e., the former, too, should be from Incan times.

In the Ethnological Museum at Leipsic there is a jar (Fig. I I b) of black earthenware from Ancon, representing a man holding a bag in one hand, and a little axe in the other. One can see that it is an axe fastened to the haft, presumably a 'T-shaped axe. The jar may date from Incan times. A similar jar from 'Tarma in the Peruvian mountains is shown in the work of HAMr. (Fig. II a).

BAESSLER ${ }^{5}$ ) reproduces a little spoon of silver, from Chancay, adorned with a man holding a hafted axe in one hand. (Fig. I2 d). The axe looks very much like a T-shaped axe with a sharply bent out edge, as has already been pointed out by BAEsster. Spoons of this type were in use in Incan times (see p. 37) and perhaps even earlier, though of this we know nothing definite.

The same kind of axe as the foregoing, is evidently held by the little figure that adorns the copper Tumi (Fig. I 2 a). BAESSLER $R^{6}$ ) has also pointed this out; the figure is

\footnotetext{
1) MI. f. Y. B. V. A. 36,325 .

2) Carabuco, II. f. V. B. V. A. I $2+13$.

3) Ambrosititr. El Bronce, Fig. 19 c.

4) Plate 1.54 (Alperuanische Kunst).

5) Plate 12, I ig. 16.3 (. Ntperuanische Metallgeräthe).

- Plate 29, Fig. 173. (Altperuanische Kunst).
} 


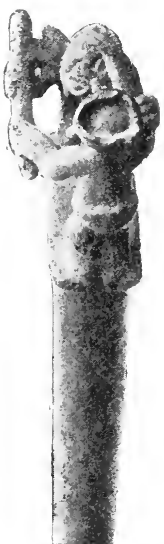

A

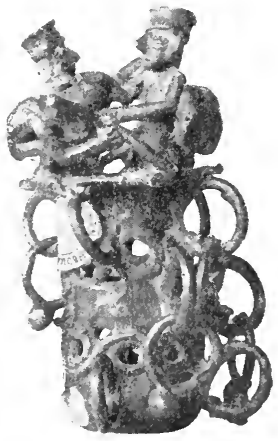

D

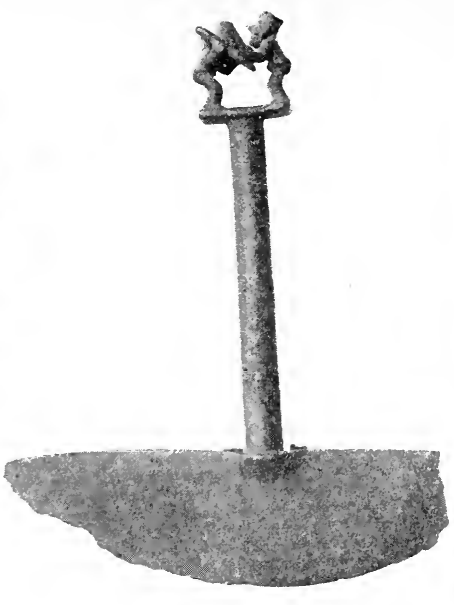

B

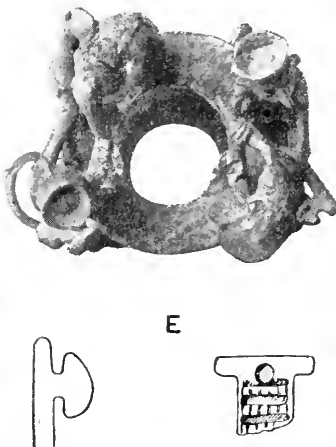

A 1.

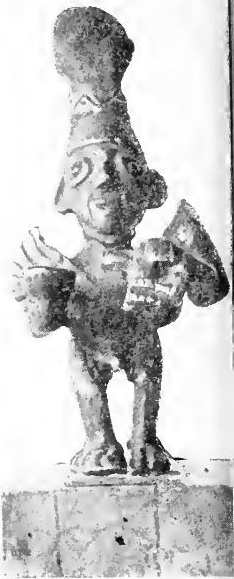

C

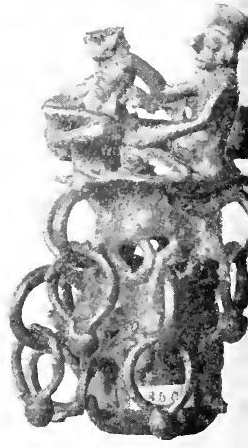

F

Figs. $\mathrm{I}_{3} \mathrm{~A}-\mathrm{I} 3 \mathrm{~F}$.

Copper and silver objects at the Trocadero museum in Paris.

A. B. 'Tumi of copper, Pacasmayo, Peru. (Cat. 110. 5065). On the handle is seen nan decapitating another with an axe, the shape of which is shown in $\mathrm{A}$

C. I'igure of silver with axe. I'ron P'eru. (Cat. no, 21II6).

Cr. shape of axe in $C$.

I. I: 1 . Object of pure copper representing decapitations. (Cat. no. Is $5_{500}$ A I - shows the shape of the axes. 
taken from his work. It is highly probable that this, if it were analysed, would prove to be bronze.

In the 'Trocadero Inuseum there is a tumi (Fig. I3 $\mathrm{B}$ of copper from Pacasmayo in Peru ornamented with two figures of which one is decapitating the other with a similar axe (fig. $\mathrm{I}_{3} \mathrm{AI}$ ). The same scene is depicted on another curious object of pure copper (Figs I3 D, E, Fi,) that has been described and figured by VERNEAU $\left.{ }^{1}\right)$. Very strange is a small figure of silver from Peru that is kept in the Trocadero Museum. It represents a man holding a bowl in the left hand and a 'l.-formed axe in the right. In the niddle of the axe is a little groove that probably was meant to represent a hole through it. (Fig. I3 C).

The Ethnographical Museum in Stockholm has a very fine, but badly worn woven fabric (Fig. If), on which is reproduced a demon with big corner-teeth and a huge nose. In one hand the demon holds a hafted axe, and in the other a human figure, which he appears to hold by the hair. Right in the middle we can also see an unhafted $\mathrm{T}$-shaped axe of the usual type. The fabric was bought by Lieutenant DIDRIK BILDT in Lima, and comes from the maritime country of Peru.

On the fabric we cannot, of course, see of what material the said axes were made. The simple ' $\mathrm{T}$-shaped axe may just as well have been of stone as of metal. But the latter assumption is the more credible, and is still more likely to have been the case with the hafted axe. The fabric is in the Tiahuanaco style, and shows that the types of axes reproduced were in use during the Tiahuanaco period.

Also in the Tiahuanaco style is a woven fabric from Pachacamac, reproduced by UHLE $^{2}$ ) in his famous work on this place. It shows us a demon holding in one hand an axiform knife or Tumi, and in the other a decapitated head.

(2).

2) (2) Pl. 4, fig. I a. 


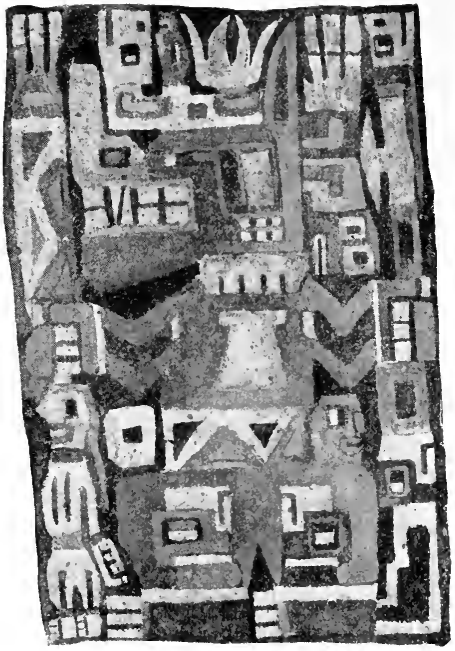

a

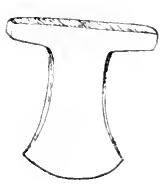

c

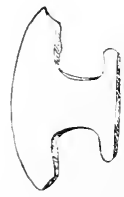

$\mathrm{b}$

liig $1+a-1+c$.

a. Detail of a piece of weaving in Tiahuanaco style bought in Lima. (Cat. no. R. M. Io. 4. 90). $1 / 2$. The demon is holding a hafted axe presumablyof the shape shown in b, a bronze axe from Covendo in Bolivia. In the middle of the demon's body appears a 'T-shaped axe like the one in c, which is a bronze axe from Quiaca in Peru. 
The scene on this fabric in the Tiahuanaco style, is evidently the same that can be seen on several articles of pottery from the north coast of Peru. (Fig. $7 \mathrm{~d}$ ).

WIENER ${ }^{1}$ ) has shown a poncho from Ancón on which are seen demons with 'Tumi-knives.

On a copper disk from 'Tiahuanaco is reproduced a type of axe which has been found, with various points of difference, in Argentina. (Fig. I5). It is a socketed axe but the haft of the axe reproduced on the copper disk looks like a piece of string. This type of axe is also characterized by having a hook on one side. 'This, too, can be plainly seen on the copper disk.

On other copper disks of the same kind²) from Argentina we can also see axes reproduced, though their shape is less distinct than on the first-named disk. One disk, shorn in Fig. I6, is evidently a poor copy of the disk in Fig. I5. Compare, apart from the axes, the position of the arms and the whole ornamentation, such as the chequer pattern on the arms. The disk in Fig. I6 should also be typologically younger than the one in Fig. I5. AmBroseTTI ${ }^{3}$ ) reproduces a disk of another type, adorned with two human figures, one of which is holding an axe. (Fig. I6 c). The shape of the axe cannot be made out from the picture.

The specimens that have been found of these socket axes are of pure copper or bronze. They have not been analysed. The central figure on especially one of these copper disks (Fig. I), resembles the central figure on the famous gateway as well as a colossal stone head which is also from Tiahuanaco, and which is kept in $\mathrm{I}$ a Paz.

1) Fig. P. 47 .

2) Ambrosetri, El Bronce, Fig. 76 and Fig. 79 .

3) Ambrosetri, El Bronce, Fig. 95 c. and Fig. 83 c. 

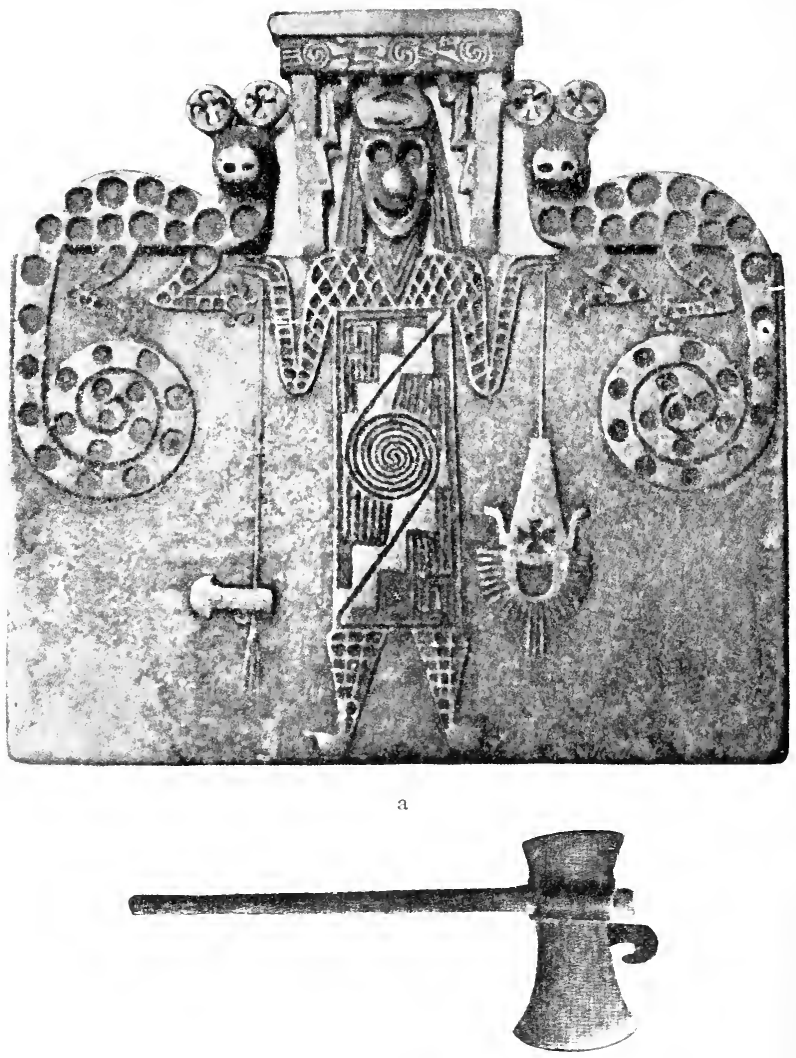

b

Iigs. I.5 a and. 1).

a. Copper disk from 'Tiahuanaco. In the right hand the man holds an axe shaped like the one shown in b. (After Posxansky (I))

b. Copper axe from Pampa Cirande, Argentina. (After Ambrosetri, Iil Bronce, fig. 56). The haft is modern. 


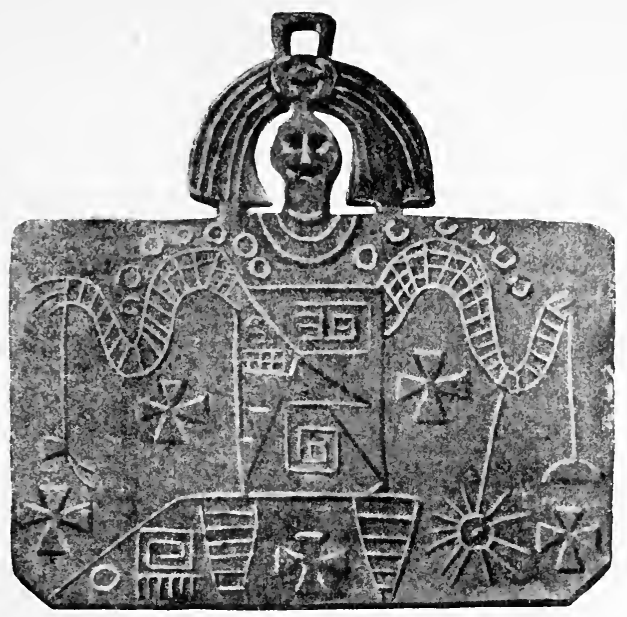

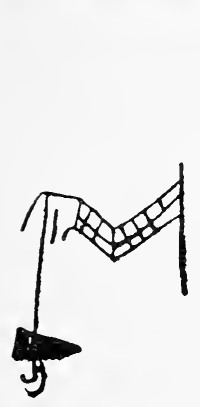

a

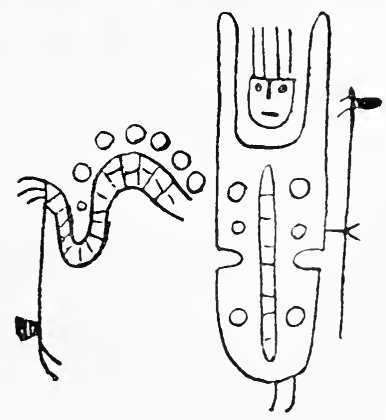

$\mathrm{b}$

c

Iig. I6, and I6 a-c.

Fig. 16. Copper disk from La Rioja (After Ambrosetri, El Bronce, fig. 76). ${ }^{4} / 5$.

a. Drawing of an arm with an axe on a copper disk from lolombon, Argentina.

b. Detail of $\mathrm{I} \sigma$.

c. Figure on a bronze disk from Chicoana, Argentina. a, b, c, After Ambrosetti, Eil Bronce, fig. $8_{3}$. 
It consequently seems to follow, from what we have gathered about representations of axes and knives on fabrics, pottery, etc., that axes with a little hole in them were known along the northern coast of Peru during an early period of culture. As we shall see, these axes have a northerly distribution, and, as far as they have been analysed, have proved to be generally of pure copper. A typologically primitive type of 'Tumi-knife is also reproduced on vases from this early period. Hafted or unhafted ' $\mathrm{l}$-shaped axes are not represented on these earthen vessels, which are typical of the culture of the northern coastland.

We find the ' $T$-shaped axe reproduced on a woven fabric in the Tiahuanaco style, and on two vessels one from the coast of Peru and the other from the mountains. Round-edged hafted axes, presumably 'T-shaped, are reprodnced on the above-mentioned fabric and on a spoon and on two Tumi-knifes. These metal objects are of types that we also come across in the mountain districts of Peru and Bolivia. Even on another object of pure copper we find this type of axe reproduced.

On a piece of pottery in the Inca style from Pachacamac, is represented a Tumi of a type which, besides on the Peruvian coast, we come across both in the district of $\mathrm{L}$. 'Titicaca and in Argentina.

The weapons and implements reproduced on pottery and textiles in the Tiahuanaco and Incan styles are evidently, as we might expect them to be, of an international type which obtained its distribution by the spread of the monntain culture in Tiahuanaco and Incan times. They are of types which, as far as they have been analysed, have most often proved to be of bronze

We have seen that the axe with a hole for the haft, and with a hook, is reproduced on a copper disk from 'Tiahuanaco, which appears to have been influenced by the Tiahuanaco style.

On a quantity of earthen vessels from the coast of Pe- 
ru can be seen figures of warriors with clubs in their hands. Some of the clubs are with star-shaped heads, others with circular heads. It is impossible to determine whether the heads are of stone or of metal, as the Indians had stone and metal ones of precisely similar shape. It is also certain that clubs with stone rings were in use at the same time as those with metal heads. In the Insenm at Gothenburg we have some very well preserved hafted clubs from Ica, with stone rings that are fastened to the haft with raw-hicke. These clubs cannot possibly be from a time when metals were nnknown on the coast of Pertu. They are probably of the same age as the finely carved paddles or spades from the same place, which are presumably from the Inca period. LAS CASAS ${ }^{1}$ ) says that the Indians in Peru had both clubs with stone heads and clubs with metal ones.

Adormments that were evidently of metal are not rare$1 \mathrm{y}$ to be seen reproduced on pottery. On a number of ressels from the coast of Peru we see nose-ornaments of metal ${ }^{2}$ ), possibly of gold, but sometimes probably of copper. On an earthen vessel from Ancon, reproduced by SELER, there are tweezers worn as an ormament on the breast $\left.{ }^{3}\right)$. It is, of course, impossible to say of what metal they consisted.

$\left.{ }^{1}\right)$ P. I94 "y peleaban con unas porras que traian ceñidas y eran de piedras horadadas, y otras de netal ó cobre a nuanera de estrella con $11 n$ astil que les pasaba ior nedio, cuasi de cuatro palnos."

2) See, for instance, BAESSLER (2) Pl. 24. Fig. I I and Fig. I1 5 (sixpointed morning star), P1. 37, Fig. 196.

See, for example, Seler (I), P1. 16, Iig. 15, Pl. I9, Fig. 12, etc. BAessler (2) P1. 22, Fig. 97 \& 99, P1. 24, Fig. 113, etc. RIVET and VERNEAU reproduce similar nose-ornaments of copper from Ecuador (P1. XXII).

3) SELER (I), Pl. II. Ancon. This figure shows that tweezers were worn on a band round the neck. This confirms my assertion that the silver "boivéra" worn in a sinilar manner by the Chiriguano Indians can derive from tweezers. (See Nordenskiöld (3), Fig. 26). 


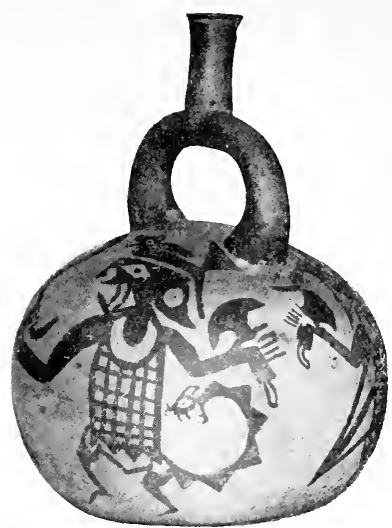

Fig. 17. Vase from Chicanra ornamented with demons carrying axes. (Cat. no, G. M. 20, 9. 31).

\section{CHAPTER III.}

Copper Objects of which the Age can be dietermined from the Circumstances of the Find.

I have now given an account of what I have succeeded in finding in the old literature about the use of copper objects in S. America at the time of, and shortly after, the conquest of the Inca Empire. I have moreover searched out representations of objects of this kind copied from pottery, textiles etc. found in s. America. I will now pass on to a summary that I have made of the copper articles that have been found under conditions which enable us to draw some conclusions about their age.

It is only a very small part of the quantities of archæological objects collected in museums and published, that were so described as to enable us to know anything about how they were found. Rarely have the contents of each particular grave been kept together as an entity. 'This is the 
reason why our knowledge of the chronology of the different cultures in the west of $S$. America is so uncertain.

Another unfortunate factor is that sone of the really good investigations have yielded very few finds of copper articles.

We know that certain types of pottery, e. g. aryballi, are characteristic of the Inca period. 'This may be considered as fully proved by the investigations of Umis, B.xDİLIER, and JIJÓN Y CAAMANOO.

In Machu Picchu, the city of ruins examined by BINGHAM and LATON, copper articles have been found together with such pottery. In I a Paya, which Ambrosertit examined, and about which comparative studies have been made by Uhi.e, were found Incan pottery and copper articles. BLAKE made similar finds near Arica, as did DoRsir in Isla de la Plata off the coast of Ecuador. EwBdNk, again, speaks of finds of copper things together with Incan pottery in a grave at San José near Rio Maypu in Chili. UhLE examined graves at Pachacamac which are without a doubt from Inca times. These are the graves that originated in the so-called burial place of the maidens of the surl. UHr.E also found some other graves with Incan Pottery at Pachacamac.

Below I have tried to put together the finds of copper objects made at the places named.

If we begin with the finds from Machu Picchu, there are spoons, (Fig. Is a, v), l'tuni-knives (Fig. Is b, g, h, j, q) a curiouse knife with a side edge (Fig. Is c), a ball (Fig. IS d) the blade of a hoe (Fig. Is e), a pin with a starshaped head probably representing a miniature club (Fig. Is f), topus with round or half-moon shaped heads (Fig. I $8 \mathrm{i}, \mathrm{m}, \mathrm{r}, \mathrm{s}$ ), a $\mathrm{l}$-shaped axe (Fig. Is $\mathrm{k}$ ), a needle with an eye (Fig. IS 1), mirror? (Fig. IS 11), tweezers (Fig. I\& o, $\mathrm{x}$, y) a pendant (Fig. Is 1 ), crowbar? (Fig. Is $t$ ), and a topu with a round head (Fig. Is w).

Of these only the finds made by Eaton himself (Fig. Is $11-y)$ are with absolute certainty of the same age as the Incan pottery. 
38

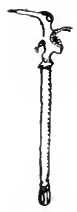

a

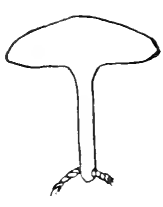

b

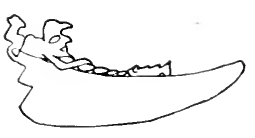

c

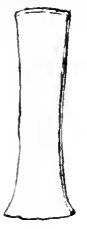

e

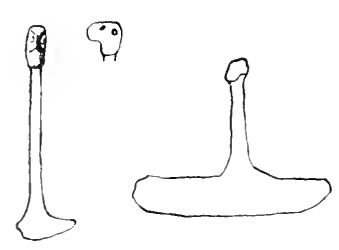

g

h
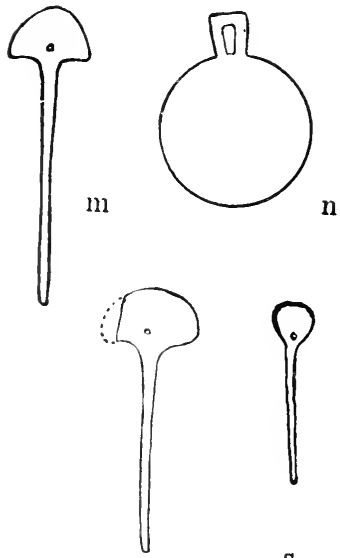

r

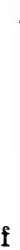

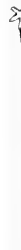
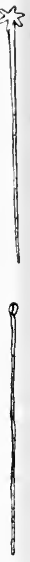

1

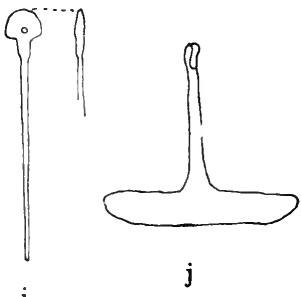

i

o
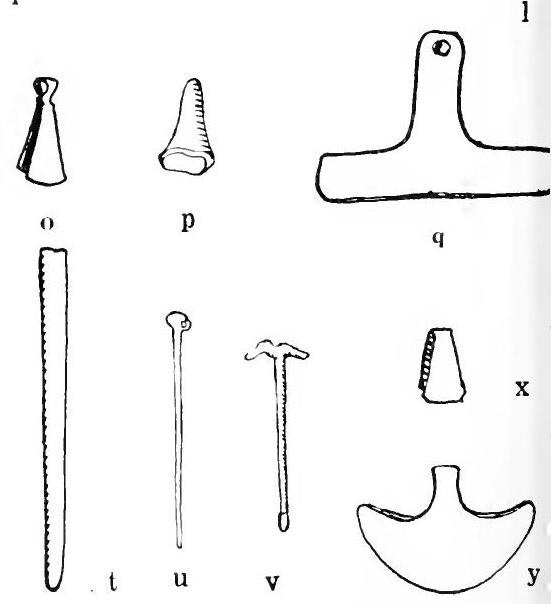

d

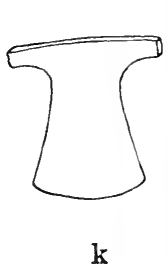

q
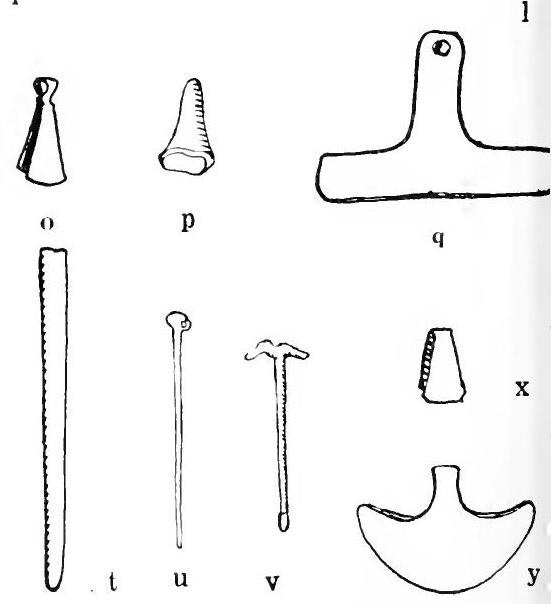

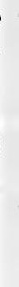

Iigs is a is $y$ copper ohjects that have been found together with lncan Pottery.

a-1. Machu l'icchu. Ifter Matmensox.

a. spoon. b. Tumi. c. Knife. d. Ball. e. Blade of hoe. f. P'n. g. Tumi 1. Tumi. i. Topu. j. Tumi. k. T'shaped axe. 1. Needle with eye. /Fo1 sizes, see Mathewson.)

nu-y. Machu l'jechn. After Exrox.

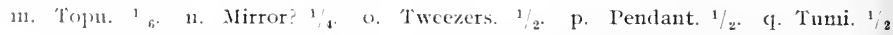
r. Topu. ${ }^{1}{ }_{5}$. s. Topu. ${ }^{1}, 3$. t. Tool of rectangular shape. Probably a stonc mason's point. ${ }^{1} / 10$ u. Topn. $1 / 2$ V. Spoon. ${ }_{1 / 2} x$. Twcezers. ${ }^{1 / 2}$. y. Tweezers. $1 / 2$ 
We shall find, later on, that the majority of the metal objects from Machu Picchu are of the types we come across throughout the territory held by the Incas when the spaniards conquered the country.

AmbrosetTi, as we have mentioned, found graves with Incan pottery at La Paya. A number of the graves had pottery of only local type. In graves with undoubtedly Incan pottery ${ }^{1}$ ) AnBRosetri found the following copper objects: -

In grave 6I a square breastplate (Fig. I gk $\left.)^{2}\right)$, a 'T'-shaped ornament (Fig. I9 o), and a ball (Fig. I9 1).

In grave I 6 a square breastplate, part of a half-noon shaped knife and the blade of a hoe (Fig. I9 n). In this grave there was only one vessel; it was of Incan form, and with local ornamentation.

In grave I6r a square breastplate, a chisel, two tweezers (Fig.I9 j), a ring, two "chapitas", one round, the other square and provided with a little hole, a little parrot, and other things. AmBrosetTi assumes, probably rightly, that the parrot had served as an ornament on a knuckleduster of a type that was not rare in $\mathrm{N}$. Argentina.

Among the finds called 74 by Ambrosetri he found a little topu (Fig. I9 $\mathrm{m}$ ) with some Incan pottery.

The graves of La Paya containing pottery of a local type are presumably not much older than those with Incan pottery. Among the ressels found by Anbrosettr are a conple with Incan shape and local ornamentation. We meet with the ostrich figures that are so characteristic of the Calchaqui 11rns, on vessels of obviously Incan shape. Here, consequently, the local ornamentation was continued even after the shape of the Incan vessels had become familiar.

1) UhLе (4) (p. 512) considers graves 61, I 16 , and I6I to be Incan.

2) The objects I have been able to identify from the photographs and drawings in AMBroset'TI's work, are reproduced in Fig. I 1 . 


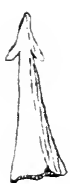

a

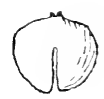

b

c

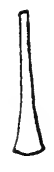

d

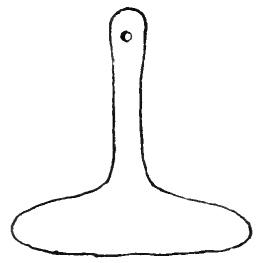

1

h
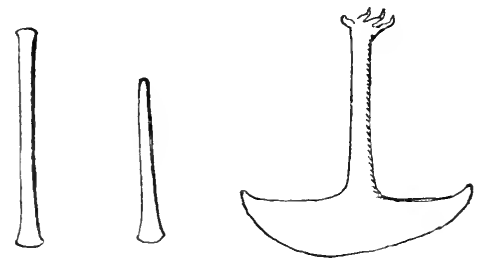

$\mathrm{p}$

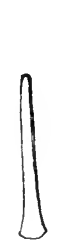

q

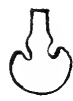

$\mathrm{j}$

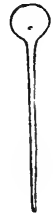

m

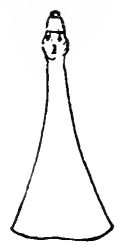

f

g

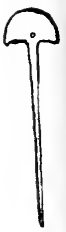

(

e
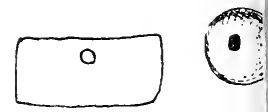

$\mathrm{k}$

1

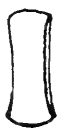

$\mathbf{n}$
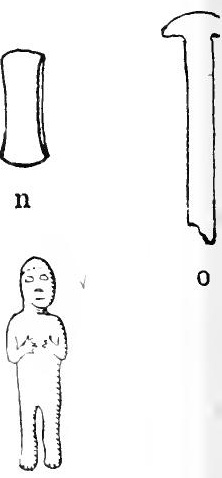

0

S

Irigs In a-19 s. Copper Objects that have been found together with Incan Pottery.

a-g. Pachacanac. Ifter THLe (2).

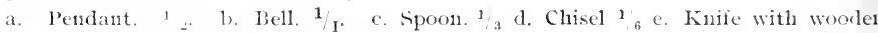
liaft. ${ }^{1 / 6}$ f. Finife, ${ }^{1}{ }_{3}$ e. Topu. $1 / 6$.

11, i. Bay of Chacota, Peru, (now Clile). After Br.AKE (p. 289). h. 'Tuni. i. 'Tuni. ${ }^{1 / 2}$.

j o. I a Paya, Salta, Argentina. After Ambrosetri. (3). j. Tweezers. k. Breast of nanent. 1. Mall. 11. Topu 11. Blade of hoe. O. T-shaped ornament (size no stated by AMBRoSETTI

1) r. San José, Rio Maipu, Chile. After Lìnaxk. p. Chisel. $1 / 8$ q. Chisel. ${ }^{1}$. . r. 'Tumi. ${ }^{1}$

s. Snall luminan fignre found l,y IOKSES on the Island of La Plata, Ecuador. 1. 
In general Ambroserti found the same kind of copper objects in the graves containing pottery of Incan type as in those with pottery of local type. In grave I36, which, as far as one can judge from the poor pictures, only contained pottery of a local type, Aubrosetri found a socketed axe which resembles the one depicted in Fig. ${ }_{5}$ b. In the same grave, moreover, he found a 'T-shaped ornament of a type like that of one found in grave 6I with typically Incan art. In grave $16+$ he found one of those famous "discos" which seem to have been characteristic of the Calchaqui district. Only one vessel of less characteristic form was found in this grave.

From the cemetery of the sacrificed women at Pachacamac, UHL, $E^{1}$ ) reproduces a copper shawl-pin (Fig. I9 g). 'This burial-place is from Incan times, so that the topu must be of the same period. The shape has a very extensive distribution. Among the objects found in this cemetery were also two copper bells (Fig. I9 a, b.). Both types, says UHLE, are numerous in graves in the highland, for instance in Northern Bolivia, which is a proof of their Cuzco origin.

From Inca times are also the copper objects UHLE reproduces on Pl. I3, Figs. $21-26$. Among them is to be noted a knife of the type we see depicted in Fig. Ig $\mathrm{f}$, a hafted (Fig. I9 e) and an wnhafted chisel (Fig. I9 d), a little spoon (Fig. I9 c) etc. A similar spoon is reproduced by Mathewson from the Incan Machu Picchu. Uhle also found here tweezers, of which there is no picture but of which he says: "The tweezers in this burial-ground are of the usual well-known shape. One pair, possibly of later date, was found near a house in the northern part of the city. The shape is a developed form of the original bivalve sea-shell." UHLE compare these tweezers with those figured by Reiss and STḦBEL, P1. SI. Figs. $2,4,6,8$.

1) Pachacamac, I'1. I9, Fig. Io.

2)

I'. 169. 
BLAKE reproduces two knives, 'Tumis found together with Incan pottery at the Bay of Chacota, Peru (now Chile). (Fig. I9 h. 1).

A Tumi (Fig. I9 r) and a couple of chisels (Fig. I9 p, q. of bronze are mentioned by EwBANk as found together with two earthen vessels which, to judge from his pictures, (Pl. IX, Fig. II, I2), are clearly of Incan type. EwBank writes: "Figures I I and I 2 are from the same tomb, in Chile, out of which the bronze implements figured on Plate $\mathrm{I}^{1}$ ) were taken." From this it seems to follow that the hoeblade found at the same spot, which is stated to be of pure copper, ${ }^{2}$ ) was not found in the same tomb. IW did not find these things himself: they were found by some workmen who were digging a canal. 'This makes his statements about the find very questionable.

In a tomb on the Isla de la Plata, Ecuador, DORSEY found, together with some typically Incan pottery, a little human figure of bronze (Fig. I9 s), and the following other objects of copper, which he describes as follows:3) "A number of copper pendants were also found which are of interest owing to their resemblance to the type so common in the highlands of Ecuador and Peru. They average from three-quarters of an inch in length and are bell shaped, being perforated near the upper end for suspension. With these pendants was found a similarly sized object of copper shaped like a vase, with rounded bottom, bulging rim and long and but slightly constricted neck. . The usual number of metallic pins were found, and they differ in no manner from the typical specimens so common in Peruvian graves. . These. . . are of two types, one having a large, flat,

1) Pl. VIII.

2) It does not appear plainly from EWB.NK's work if he analysed the copper objects, or if he, as one is rather inclined to think, guessed at the composition from the colour. He probably made no quantitative analysis.

3) P. 258 . 
nearly cylindrical head, the other having a head much smaller, thicker and more nearly semi-circular." Of these objects the human figure is unfortunately the only thing depicted in DORSEy's work.

I will now pass on to other finds of copper objects that have been made and which have been published with due regard to the circumstances of the finds. These finds were with non-Incan pottery.

In the border districts of Bolivia and Peru I have examined several "chulpas" and burial caves $\left.{ }^{1}\right)$. In each case the finds were carefully kept together. A certain number of objects found in the graves derive from sacrifices and are therefore not of the same age as the skeletons deposited there. But this does not hold good with any certainty of the bronze objects found in then1. A number of the graves had been partly stripped before I was in a position to examine them. This is no doubt one of the reasons why not much pottery is to be found in the graves. The few vessels I found are not of Incan type, and they are consequently quite different from the finds made in the not very distant Nachu Picchu. But this does not prove that they are not contemporaneous, for it is possible that pottery of a local type existed even during the Inca time. The bronze articles found in the graves are shaw1-pins, "topus", and a needle with an eye, which was perhaps also used as a topu. I call them bronze articles because all those that have been analysed have proved to be of bronze. A number of these objects are depicted in the Tables of Analyses (see Fig. 6I).

In the province of Sara near Santa Cruz de la Sierra, I examined a number of graves in rgos. In one of them I found a bronze disk (Fig. 62f), three little silver disks, and some bone necklace-beads. The urn, with its lid and the objects it contained, are shown in my paper "Urnengräber" etc. The bronze disk has been analysed, and the result of 
the analysis is given on p. I68 of the paper. The finds I made at Sara show that bronze, urn burial, finger-print decoration, and tripedal pottery were contemporaneous there.

At Caipipendi within the territory of the Chiriguano Indians, I made a number of excavations in Igos, results of which I hope to publish in rol. $V$ of this work, Apart from a small fragment, I only found there a single object of copper. It is part of a copper band, (Fig. $62 \mathrm{~h}$ ) and on analysis proved to be of pure copper. All the implements found at the same burial-place are of stone. Besides pure copper, gold was known. The pottery in the graves at Caipipendi is of a local type. It corresponds in shape and ornamentation more closely with what has been found at Rio Parana than with the finds from the highlands of Bolivia.

With pottery of a local type - if we except that from I a Paya - copper objects, to judge from the finds published, seem to be rare in Argentina. From Kipón ${ }^{1}$ ) DeBeneDETTI mentions a little pendant and a square breastplate of copper. He gives no pictures of them. In Pampa Grande numerous copper objects have been fonnd, but AmBRoSETTI himself, who excavated a quantity of graves that had pottery of local type, only found a few simple chisels and "una punta de hachnela». ${ }^{2}$ ) It is not clear, as far as I can make out, from his work whether these finds are from graves or dwelling-places. They have neither been analysed not depicted. From 'linti Bomax ${ }^{3}$ ) describes and pictures some copper disks, of which he analysed one (Fig. 43. 17) which proved to be of bronze. Pottery of a local type was found at the same place.

BRUCi, in a comple of graves at Hualfin in Argentina that he carefully examined, found two square copper disks and a pair of copper tweezers that were not folded t1p;

1) (I) Cirave 4 and grave 5 .

2) Ambrosititi (2), p. 162 .

3 ( 2 ) 
the pottery found there was of local type. It would be of great interest if these copper objects were analysed. Such finds as these from Argentina should be analysed in order to discover whether bronze objects are also found there with nonIncan pottery, and to find there, if possible, objects from the Copper Age.

'The square copper disks are of a type that has been found at La Paya with pottery of both Incan and local tyje Also tweezers of a very similar type have been found in several graves at Ia Paya.

In a monnd at Paraná Guazú 'l'orres came across some small disks of bronze. As the place of the find is outside the old district of the mountain culture, it is not possible to compare the finds made there with what has been found in the cultural district of the west, from which these bronze objects must derive. 'IORREs' excavations were carefully. carried out.

(On the coast of Peru have been found quantities of copper objects with pottery of a local type. These finds have unfortunately not been so published as to show that the contents of the different graves have been kept together. In graves at Pachacamac, which UHLE ${ }^{1}$ ) considers to belong to "the later pre-Inca period" he found two tweezers. One is in the form of a human being, the other has the same shape as the tweezers shown in Fig. $32 \mathrm{c}$. It is of a typologically old type (see p. 75), which has proved on analysis to be of pure copper.

It would be of the greatest interest if we had some reliable finds from the Tiahuanaco graves, including copper objects. Courtr has made some, but they are not yet published (see p. 90).

In Tiahuanaco have been found a number of clamps of pure copper), (Fig. 39, I-7), which were for fastening together blocks of stone. They are the only metal objects pub-

1) (2) P1. 7, fig. 8,9 . 
lished from Tiahuanaco of which, thanks to the circumstances of the find, we can say that they are contemporaneous with the famous ruins.

From this collocation we can see that we know quite a number of types of copper objects found with Incan pottery. The reliable finds we have of copper objects found with non-Incan pottery, are comparatively few.

It is regrettable that UHLE has not had an opportunity of publishing a full account of his material of grave-finds from various parts of Peru and Bolivia like the one he gave us from Pachacamac. We should then have invaluable material for the study of copper objects from various periods and localities. The contents of each grave must, however, be published as an entity, which was not done in the Pachacamac work.

In a note to a paper ${ }^{1}$ ) dealing with the Peruvian influence in Argentina, UHLE has some interesting remarks about the age of various copper types. Though he brings forward no detailed 1,roofs, his statements are valuable, being based on unprecedented experience.

According to UHLE, the star-shaped club-head of copper is common in collections from Cuzco and in graves from Inca times.

The type of axe in Fig. $20 \mathrm{~b}$, according to the same anthority, is typically Incan, and is found in collections from Cuzco.

Of the form of knife knowns as "Tumi», (Fig. 2I), UHLE says that it is Incan, and Incan alone. Under 'Tumi it is therefore to be presumed that UHLE does not include similar knives of a typologically primitive type. The have seen some such copied on earthen vessels from the Perurian coast districts which UHLE himself considers to be pre-Incan.

The ordinary ' $T$-shaped axe, which is the original type of most of the metal axes found in S. America, is also api) (4). 539 . 
parently considered to be Incan by Inis:. It is not reasonable to suppose that it was not until Incan times that this form of metal axe was made. 'This would only inply. that within a large area of the cultural region of the west it was not nutil Incan tines that they began to nse metal exes, since in a large district no metal axes have been found which cannot derive, typologically, from this type of axe.

We have seen that such axes are reproduced on a woren fabric in the Tiahuanaco style from the Peruvian coast. A forn of axe which, as we shall see, can derive, typologically, from the 'I'-shaped axe, has already been noted as reproduced on a copper disk that seems to have been influenced by the 'Tiahuanaco style. 


\section{CHAPTER IV.}

\section{International and Local Types.}

I will now pass on to speak of the geographical distribution of various types of copper objects. Such a study, coen if we only know' where, and not how these objects were found, may contribute to our knowledge of their relative chronology. RIVET and VERNEAU have conscientionsly studied the entire American distribution of the forms of copper implements, ornaments, etc., that have been found in Eicuador. Some have proved to have a very extensive, others a more local distribution. Basing my study mainly on their researches, I have put together in tables the types of copper objects that have been found in the whole, or almost the whole, territory of the Incan Empire at its greatest extension, and such types as are characteristic of a part of the territory occupied by the Incas at the time of the Conquest. These international types of copper objects have very largely the sane distribution as the earthen vessels which I mentioned in the foregoing as being characteristic of Incan times. It is therefore probable that those forms of 
copper objects whose distribution corresponds to the extent of the Inca Empire at the Conquest, were in use in Incan times.

In studying the distribution of the types, it is of importance not only to discover the distribution of, let us say, a certain kind of implement, but also to discover the various forms of this implement.

It was of course impossible to include everything, so I have tried to select forms that are characteristic.

Several of the international forms, such as some types of 'Tumis, the hoe-blade, chisel, Topu with round or crescentslraped head, bells, needle, tweezers of the kind depicted, 'T-shaped axe, and "mirror' are among the forms that have been fonnd with undoubtedly Incan pottery. Both the circumstances of the finds and their distribution thus show that these types were in use in Incan times.

Of these international types, the Tumis, Topus, with big round heads, clubs with star-shaped heads, and mirrors are mentioned by writers who were in a position to observe the Indian culture while it was still original. These things were consequently still in use in the I6th century.

We see therefore that the majority of these types of copper objects that are met with throughout the territory of the Incan Empire, are such things as, for other reasons, we have every cause to assume were in use in Incan times. I believe, further, that it was not until Incan times that they obtained a distribution that corresponds remarkably well with the maximum extent of the Inca Empire as we know it from historical sources. This does not imply that all these types first came into use in Incan times. They may have occurred in a restricted area before that. This is especially true of the ' $T$-shaped axe and the chisel. From the former, as we shall see, a number of forms have certainly developed which required a considerable time, while the latter is also a very primitive type of implement. 
Forms of Copper objects which occurred throughout or almost throughout the Inca Empire.

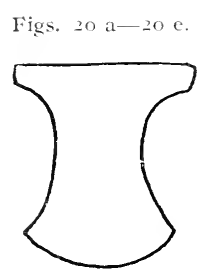

a
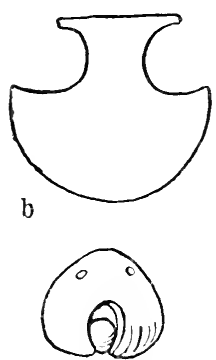

c

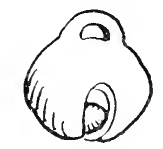

d

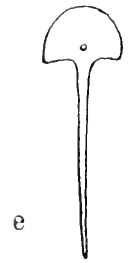

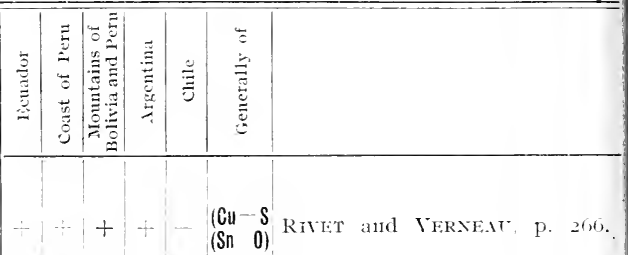

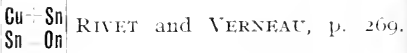

Bell

?

RIVET and VERNEAL, T. 313.

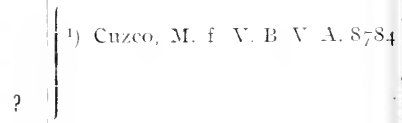

RIITT and VERNEAC, Pl XXI, fig. 13.

'opu

2) BAESSIER (I), Pl. If, fig. 210

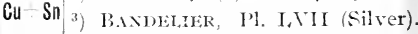

4) Mibrosfettr (t), fig. 3 I e.

5) Mrinsi, fig. IзI. 
Forms of Tumis which occurred throughout or almost throughout the Inca Empire.

Figs. $2 \mathrm{I}$ a 21 t.

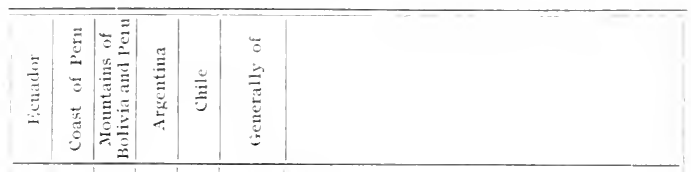

1) B.ASSIIIK 11, I'l, 5, fig. $15,4^{6}, 47$ I'I. 7, fig. of \&, M. 21, I. 7 (Clhatncay).

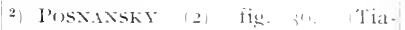
$\mathrm{Cu}+\mathrm{Sn}$ huanacol.

(Sn 0) MAthis Machu P'icchu). R. MI, (x), 1, 1 ‘o Quiaca).

3) Ambrosetti (3), fi: 221 . BoMAx (1), T, I, fig. 1 t.

4) I.Aтcili (Paposo), P, 12.

1) RIVET and VERNFA', I'IX, IIE 5. Cu Sn ${ }^{2}$ BAFSSI.FR (1), fig. HI.

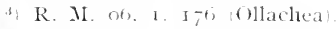

a IMBRostiT'T /I), fig. In

1) RIVET aI1 VIKXEAT, I'I XX, fig. I 3 .

2) B.HSSI.EK 11 , I'l. 5, fig. 13.

$\mathrm{Cu} \mathrm{Sn}^{3}$ M. f. V. B. V. . 1. I $2,-8$, , Tiar-

(Sn 0) linanaco (i, M. 2I. +. I (Cizuco).

4) IMBRoslittit (1), fig. IG b.

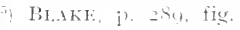

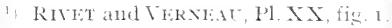

2) PAESSI,FR, Pl. - Hig. 62 .

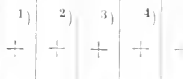

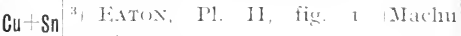
(Sn 0) licclut).

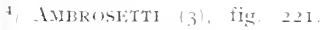

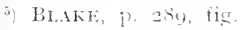

1) Siee this book 1. 24 .

II f. V. I. V. I. it:i25, Chit(quitanta).

2) II. F. V. B. T. A. 12413. Carabneo).

3) Aubkosiztre fig in 6 
Forms of Copper objects which occurred throughout or almost througho the Inca Empire.

Figs. $22 \mathrm{a}-22 \mathrm{e}$.
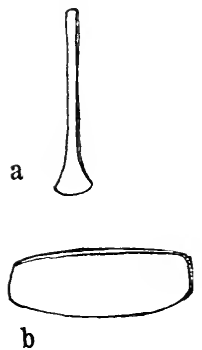

Kinife

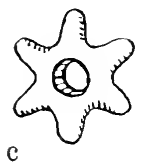

d
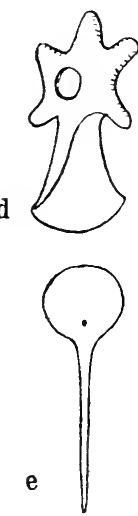

Clubhead

Clublead with axeblade Topn
1) BAESSI,ER (I), Pl. IO, fig. 8 2) MEAD

CU+Sn NordFiskiö, (I).

(Sn-0) 3) AMbrosetrit (I), fig. Io.

4) Latciali fig. p. 6 .

1) BAESSl,ER (I) P1. 8, fig. 75 .

2) NORDENSKIOLD (I).

3) AMBrosetTi (I), fig. 9.

4 Latcilan, fig. 5 , p. 13.

CU Sn RIVFT and VERNEAC; p. 279 2) (:. M. 2I. I. 3. (Chancay).

1) JIJÓN Y CAAMANOO and IARREA Pl. Xxxix.

SAVIlle, 'T II, Pl. CXIII.

$\left.\mathrm{Cu}+S n^{2}\right)$ BANDEliER, Pl. 30, fig. 4 . IIEAD, fig. I b.

II. f. V. B. V. A. 8736,8737 (Cuzco).

1) RIIET and VERNEAL, I'I. XXI fig. I.

$\mathrm{CU} \mathrm{Sn}$ 2) BAFsst in (I), fig. 224 (Silver)

3) Iittos, I'l. II, fig. 5 . NoRdeNSKIÖLD (I).

4) Ambrosetti (I), fig. 3 I b. 
orms of Copper objects which occurred throughout of almost throughout the Inca Empirc.

Iigs. 23 a- $23 c$.
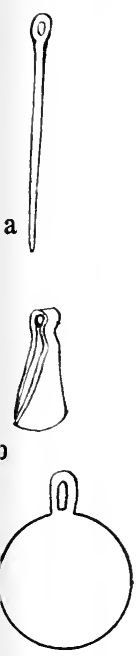

Needle

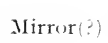

Tweezers a)

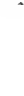

Spoontipped lanclle

Hoe.

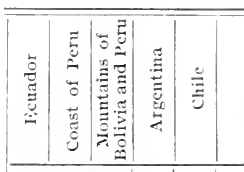

$\mathrm{Cu}-\mathrm{Sn}$

(Sn 0) RIVIT and VIEREEIT, p. 243.

1) MATHEMSON, fig. 27.

$\mathrm{Cu} \mathrm{Sn}^{2}$ ) BAESSLER (1), I'. I6, fig. 260. i. M. I6. 9. 272.

1) BAESSLEK (1), Pl. 14, fig. 300. 1) 2) 3) 4) 2 MATIEWSON, fig. 21.

3) Aibrosetti (I), fig. 4. .

4) I, ATCHAN, fig. $2,($ p. 25$)$.

1) BAISSLYK (I), fig. I 79 .

Cu Sn 2) MATHEWSOA, fig. Io. EATON, I'l. I, fig. $\%$.

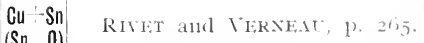

a) Tweezer oceur from Columbia to Irocutina. The form shown lere is found in the nuonutains of Peru and along the Peruvian coast. 
Forms with mainly northerly distribution in the old Territory the Inea Empire.

Figs. $2+\mathrm{a}-2+\mathrm{f}$.

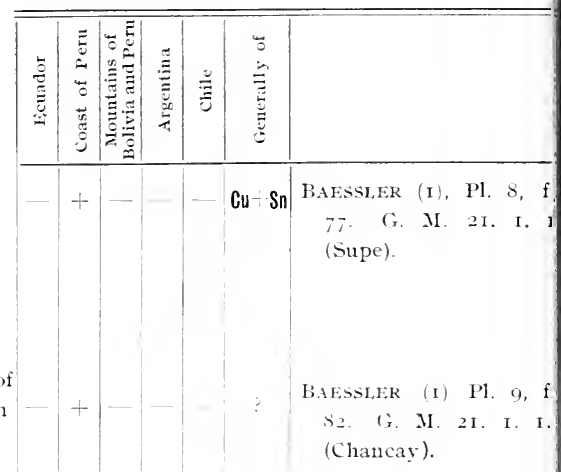

a

Knife

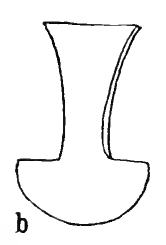

Object of unknown use

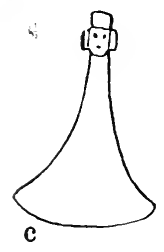

Knife

BAESSLER (I) Pl. 6, fig. 5 IHIF (2).
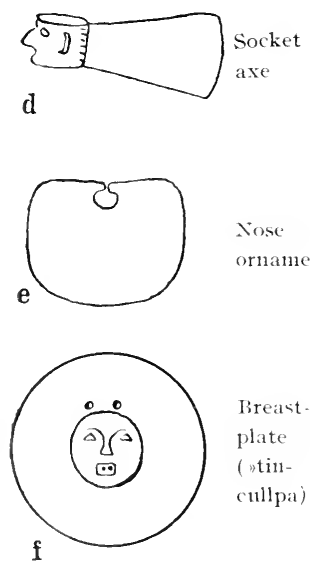

Nose

ornament

Breast.

plate

("tin-

\begin{tabular}{c|r} 
CU & RIVET and VERNEAT \\
Sn 0 & 295.
\end{tabular}

Cu RIVET and VerNeAt, Sn-O 270 .

Jores fig. $5 \mathrm{~d}$.

cullpa)

RIVET and VERNEAC Sn 0 jor.

JHóx Y C.hMAก̃o (2). 
corms with mainly northerly distribution in the old Territory of the Inca Empire.

Figs. 25 a $-25 \mathrm{f}$.
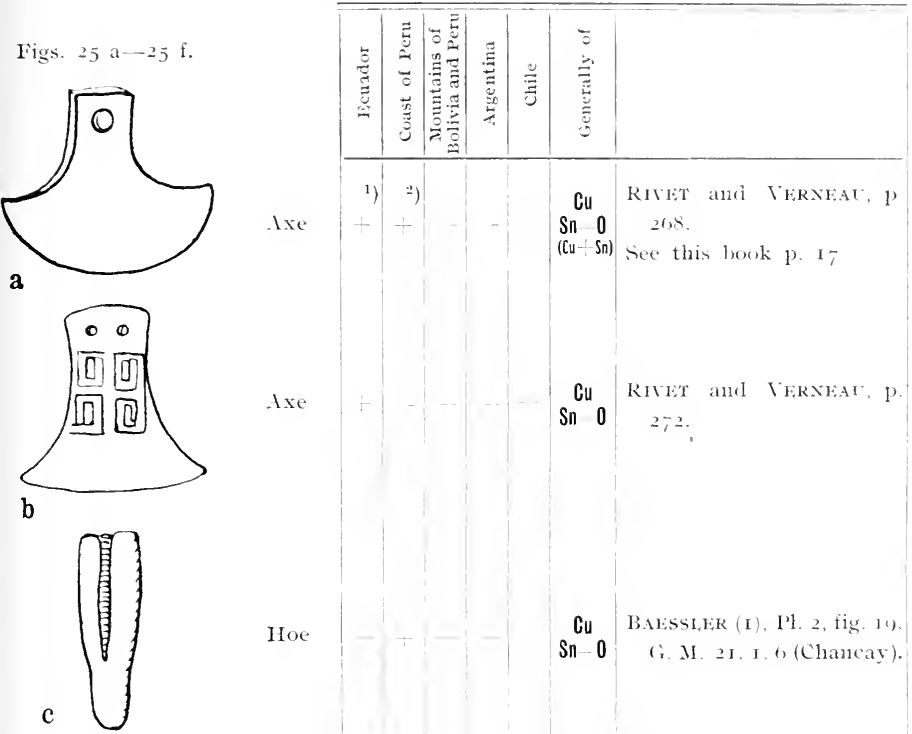

lxe

$(\mathrm{Cu}-\mathrm{Sn})$ see this look P. IT

CU RHET and VERNEAT, P. Sn $0 \quad 2 ; 2$.

Cu BALSSLER (I), I'l, 2, fig. 19)

Hoe

Sn-0 (: .1. 2I, I, t, (Chancay).

spade

Cu B.ISSI,i:R (1), Pl, 4, fig. 30. d

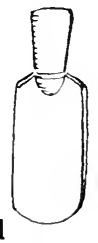

Sn 0

Cu RWET and VIRNitat, p. (Pick?)

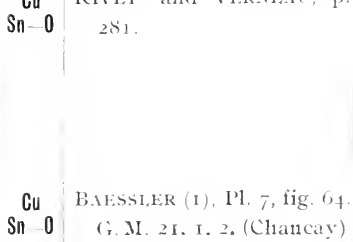


Forms with mainly southerly distribution in the old territory of th Inca Empire.

Figs. $26 \mathrm{a}-26 \mathrm{f}$.

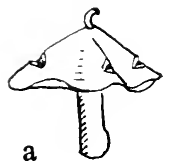

Bell
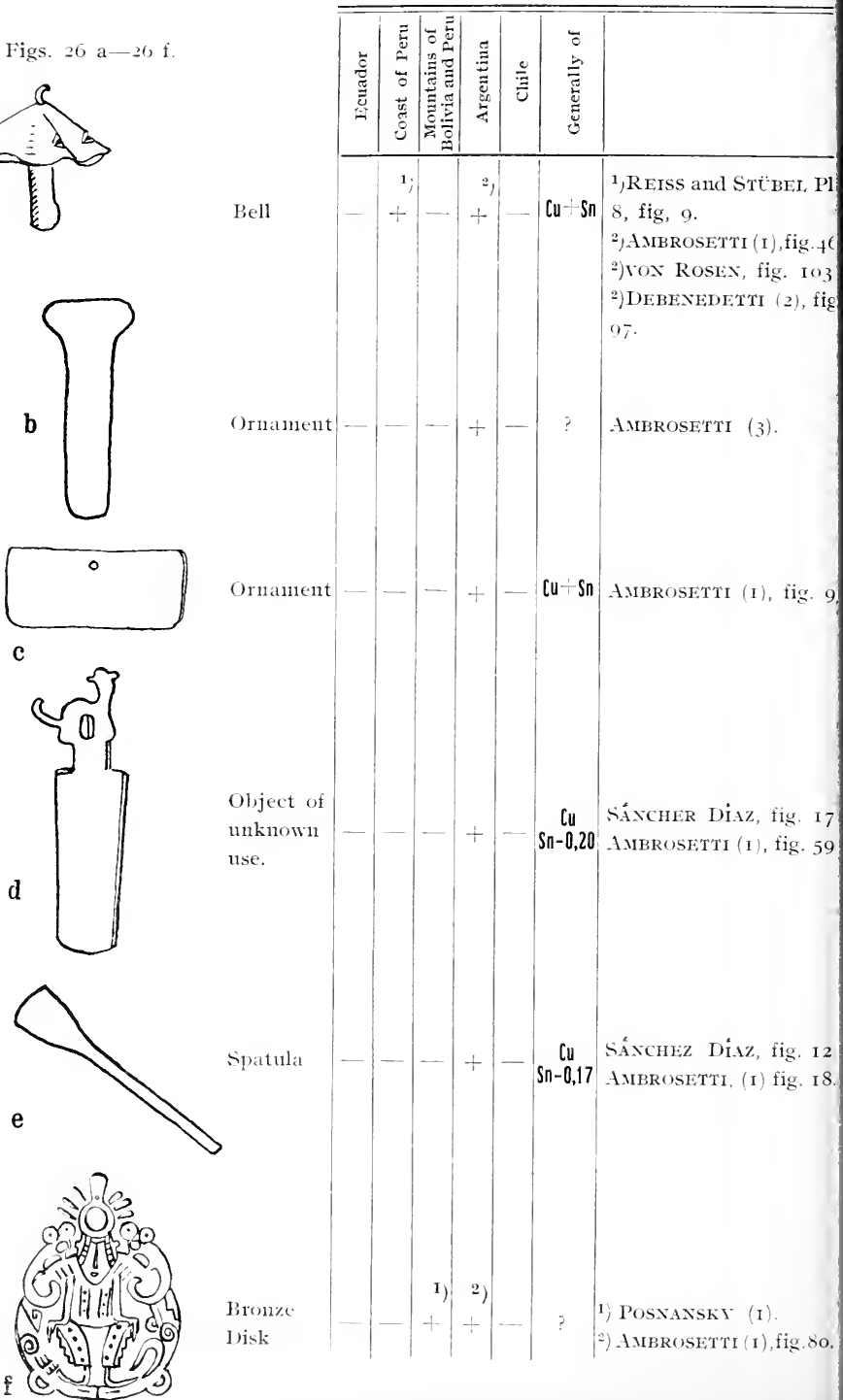

I)isk

2) AMBrosetTi (I), fig. 80. 
Forms with mainly Central distribution in the old territory of $t$ Inca Empire.

Figs. $28 \mathrm{a}-28 \mathrm{f}$.
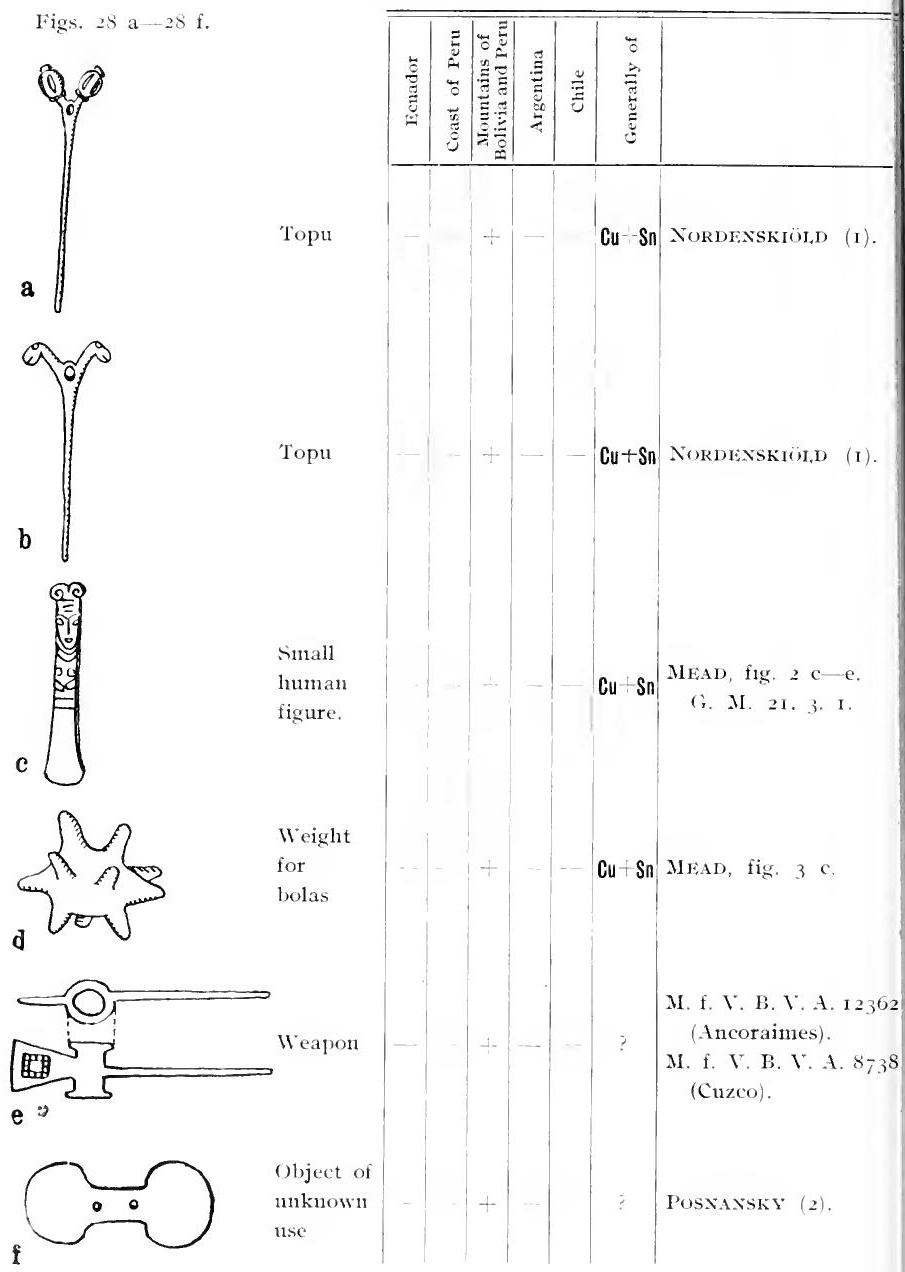
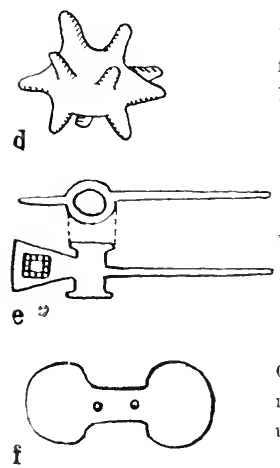

Object of nnknown usse 
We have also seen from the foregoing that 'T-shaped axes were represented on a woven fabric in the Tiahnanaco style, and that a type of axe which, as far as we can judge developed from the $T$-shaped axe, is found reproduced on a copper disk from 'Tiahuanaco that is probably pre-Incan.

If we go on to the local forms, we only find a few among them of which we know that they were in use in Incan times. To the local forms belongs the axe with a little hole, which, to judge from figures on pottery from the Peruvian coast, was in use there in pre-Incan times.

It is to be observed that some of the types of implements, weapons, and ornaments that seem to us to be local, may in reality have had a very wide distribution. Future finds will have to settle this question.

'The 'T-shaped copper axe was originally clearly a soutlern type. In Ecuador it is rare. In Argentina there have developed from it quite a number of other types of axe with a very limited distribution. I have dealt with this typological development below.

Peculiar to the Peruvian coast are implements, utensils, and weapons in which the handle is stuck in as in a socket-celt, a hafting that has had a very limited distribution in America, and a very wide one in the Old World.

Not many local types have been found in the mountain districts of Peru and Bolivia around I. 'Titicaca. Among them we may note some Topu types from "Chulpas" with non-Incan ceramic art.

It is not so very extraordinary that we do not come across many local forms in the tracts round 'Titicaca, for it is evidently from there that the international forms spread. Forms that were once local became international through Incan conquests.

'The handle of the Tumi-knife is sometimes ornamented with an animal's head, a hand, or the like, or is bent into a loop. This latter form has a particularly wide distribution. Many Tumi-knives ornamented with llama heads 
have also been found. These appear to me to be of particular interest, as there is no other kind of ornamented copper implement, as far as I know, with an equally wide distribution.

All these absolutely similar knives must be from the same period. Perhaps they were even made at the same place and afterwards spread by barter or by Mitimaes. 'Topus are still spread by barter among the Indians to places far away from where they were made. This is the case both in Bolivia and Peru. 


\section{CHAPTER V.}

\section{Typology.}

In this ehapter I have essayed, by the typological method, to draw sone conclusions that may be of interest for the anderstanding of the development of the Copper and Bronze Ages in Sonth America.

stone socket axes have, as we know, not been found anywhere in s. America. On the other hand, copper and golden axes of this kind have been fonnd here and there. River and Vervat give the localities. Copper socket axes have been found chiefly in Argentina, and Ambrosetri has deseribed and reproduced a large number of them.

By' means of these we can see how the socket axe came to be derised in S. America. An ordinary ' 1 -shaped axe was fastened to a wooden handle, as shown in the illustration. (Fig. 29 a). The blade of the axe is in the same position to the handle as in the usnal ' $\mathrm{I}$-shaped axes of netal or stone. (Iigs. $5^{6} \mathrm{a}, \mathrm{b}$ ). The difference is that it was not tied to it, but sewn to it 

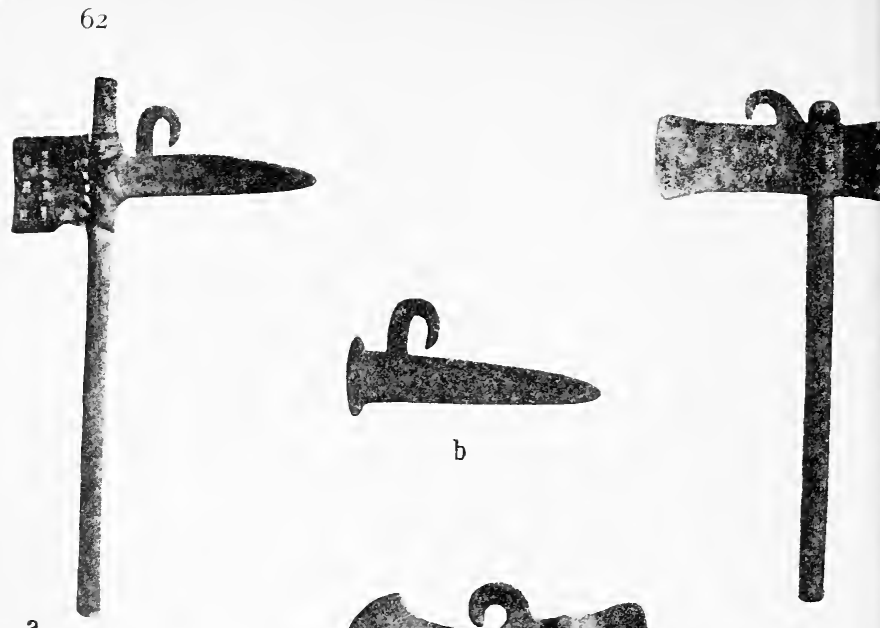

b

a

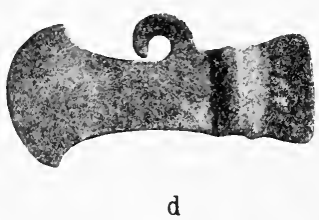

c
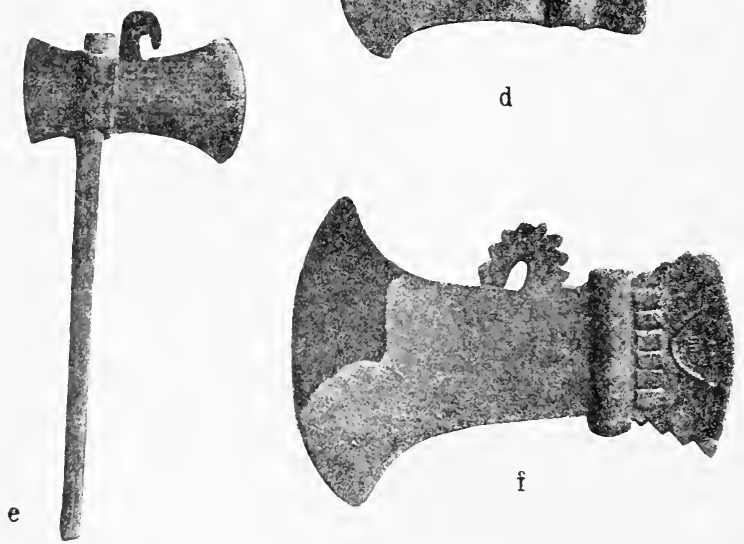

liigs. 29 a - $29 \mathrm{f}$. After Ambrosetti (Eil Bronze, fig. $5+$ and fig. 56.) $\therefore$ Copper axe with raw-hide binding, a copy of an axe depicted by LeHMaxi-Nísche from Rio San Juan del Mayo, Puna de Jujny. b. Catamarca. c. I a Paya. 1. Cañada de Belén. e. P'mupa grande. The haft is modern. f. Santa Maria. 
with leather or,to put it more exactly, with raw hide. $\left.{ }^{1}\right) \mathbb{W e}^{2}$ have a description by Giglorio of an axe of this kind from Carabuco near I, 'Titicaca. Here is Gigiond's description: "Copper Axe. I,ong and narrow, chisel-shaped; it widens slightly at the butt end, where it evidently widens further so as to have a ' 1 -shaped butt, which fits (possibly in a groove) against the wooden handle, to which it is firmly bound by a broad piece of stout raw-hide, through which the blade passes; the hide is donbled back and projects as a square appendage at the back of the handle, being kept tight by a treble stitching of raw-hide."

Gigliori says that the implement does not look old, and reminds us that ForBes mentions that the Aymara still sometimes use copper axes. ${ }^{2}$ ) LEHMANN-NiTsche ${ }^{3}$ ) has described, from a burial cave on the Rio san Juan in Puna de Jujuy, Argentina, an axe (fig. 29 a) hafted in the same way as the Carabuco one. The blade of the Puna de Jujuy axe has a large clasp, which is lacking in the other.

I here reproduce some of Ambrosetti's axes from Argentina (figs.20c-f). In these the part which in the axes fron Carabuco and Puna de Jujuy is of hide, is of bronze or copper. These axes were evidently made on the model of the hide-hafted axe. The seam which holds together the hide hafting on the axes from Puna de Jujuy and Carabuco, is, as AMBRosetTi first observed, reproduced as an ornament on the metal axe (figs. 29 c, $(1, f)$. Also on a similar axe (fig. 30,3) that B.tsssizR reproduced from the Peruvian

1) The matertal is excellent. I once happened to break the butt of ny rifle while on a journey. In Irgentine servant put the pieces together and sewed round them a piece of hide that had been thoronghly softened in water. It was then left to dry in the sun, and the hide contracted. The break was firmly mended.

2) ForBes. (1, P. 263. "I was informed that, in some very muel ont - of the - way districts, bronze and even stone axes nay occasionally be seen employed by the Indians; but I have not personally fallen in with such implements, yet can believe that this may actually be the case."

3) LEHM.N-NIETSCHE. Lam. III. Fig, 23. 
coast, can be seen the ornamentation arising from the leather seam. This has already been pointed out by Rivet and Verneau. $\left.{ }^{1}\right)^{2}$ )

Thus we see that the invention of the socket axe was made in S. America during the Copper or Bronze Age. We lave consequently here an example of an apparently not simple invention that was made independently in the New World, though much later than in the Old.

Metal socket axes are of course later than the prototype, the hide-hafted axe. Still later, typologically, is the type of axe (Fig. 30, 2 a) we have reproduced here from SÁNCHEZ DÍAz, which was found at Musquin in Catamarca. In this both handle and axe are of bronze. $\left.{ }^{3}\right)^{4}$ ) On it, too, we see an ornamentation that is evidently a reminiscence of the seam on the prototype, the hide-hafted axe.

The type of axe, the typological development of which we have seen here, may be recognized in the copper-plate I have given (Fig. ${ }_{5} \mathrm{~A}$ ). The axe which the middle figure has in his hand, has a socket and a clasp. As the copperplate seems to have been influenced by the Tiahuanaco style, it is presumably pre-Incan. If this is correct, this socketed type of axe must also be pre-Incan. This does not stand in the way of its having still been in use in Incan times.

1) P. 271 ,

2) This axe has not been analysed. As, from all appearances, it is a late type of axe, it is probably of bronze, which is also fairly clear from its golden lustre. But this can only be shown by analysis.

3) This can also be seen in a splendid axe that HEGER has described from Sierra Aconquija in Catamarca. (Fig. 30, 2 b).

To this series of illustrations I consider that the adjoined axelike weapon from Cuzco belongs. (Fig. $2 \mathrm{~B}, \mathrm{C}$ ), The blade of the axe has been turned into a long point. On the backpiece can be seen an ornament, which night also derive from the seam on the hide-hafted axes. I have already pointed out that it is presumably this weapon of which GARCILASSO DE IA VEGA speaks.

4) Contains $6.5 \%$ of tin. 
Socketed axes have been found in S. America which cannot derive from the hide-hafted axe. One such, of gold (Fig. 30, I e) and another of pure copper (Fig. 30, I f) are described by RIVET and VERnEAu from Ecuador. The gold axe at least can clearly derive from the club head of the morningstar type.

Fig. $30, \mathrm{I}$ a is a reproduction of a club head of bronze from Ecuador, of the usual type. Beside it is another from Titicaca I. One of the points is lengthened and has the shape of an axe. Still more plainly axe-shaped is the axe from Quito (Fig. 30, I c), after Jijón y CaAmas̃o and LARREA. From Ectuador is also the club head depicted in Fig. 30, I d. If we now turn to the little gold axe (Fig. 3o, I e) which I have reproduced from Gonzalez SUAREz it evidently belongs, too, to the same series. It is from Patecte near Chordeleg in Ecuador. HEYzer, according to RIVET and Verneau, has pointed out its resemblance to the star-shaped club-heads. Five of the points are very small, the sixth large and ornamented.

Here we have evidently another series, showing how the invention of the socketed axe originated. With this series I assume that we can also class the socketed axe, reproduced from Rivet and Verneau, (Fig. 30, I f) from Ganchu near Sigsig in Ecuador. One of the star points has been enlarged into the blade of an axe, the other five points reduced to ears, eyes, and nose for the face that adorns the axe. If this is not so, this particular type of socketed axe must be quite isolated. ${ }^{1}$ )

The T-shaped axe has evidently been altered, too, in such a way as to make the edge more semicircular. The actual shape of the axes has, moreover, been varied somewhat. In general we may probably regard the more semicircular axes of metal to be typologically more recent than the or-

1) Apart from the examples given by RIYrT and VisNEAC I know of only one, which is depicted by Jorce Fig. $5 \mathrm{~d}$. 
dinary 'I'-shaped ones. Yet the actual change of the 'Ishaped axes into more semicirctiar ones may already have taken place before the Metal Age, since stone axes of this shape have been found in S. America. ${ }^{1}$ ) Sometimes, too, metal axes have presumably been copied in stone. I have repro(luced such a one in a couple of earlier treatises. ${ }^{2}$ ) I do not consider it worth while to attempt to show any series of development of the $T$-shaped axes to the more semicircular types. It would not be difficult to get together a bcautiful serics showing how the edge of the T-shaped axe curves outwards more and more, but a series of this nature has no value, since we do not know whether the development has been of this regular and gradual nature. The semicircular axes are probably the "hachas de cobre", mentioned by several authors from the period of the Conquest. It is also stated of them that they were halbert-shaped. If the semicircular axes were in use at time of the Conquest, examples in bronze should be common: and this is so. To judge from the woven fabric depicted in Fig. $I_{5}$ they were even in use during the Tiahuanaco period.

In Figs. 3I we have a series of different types of 'tumi' knives. IVe can easily inagine how the development of this type of knife proceeded. 'They are all from the coast of Pert1. I have had $3 \mathrm{I}$ a and $3 \mathrm{I} \mathrm{b}$ analysed, and they proved to be of pure copper. An analysis of $3 \mathrm{I}$ e showed it to be of bronze and, as I shall shortly have an opportunity of mentioning, it must therefore be a development of a later period.

As Juón Y CAAMAÑO ${ }^{3}$ ) has pointed ont, the demon depicted in 1. 68 holds a tumi-knife in his hand, which is similar to the primitive tumi-knifes that proved to be of pure copper. This fits in excellently with the fact that the figure is from a vessel from Noche, which is considered by $\left.\mathrm{UHI}_{\mathrm{E}}{ }^{4}\right)$ to be-

1) See Rivet and Vervau, P. 155.

2) (I) P1. 5, fig. 6 .

3) (2). P. 21 .

4) (3). Fig. X. 

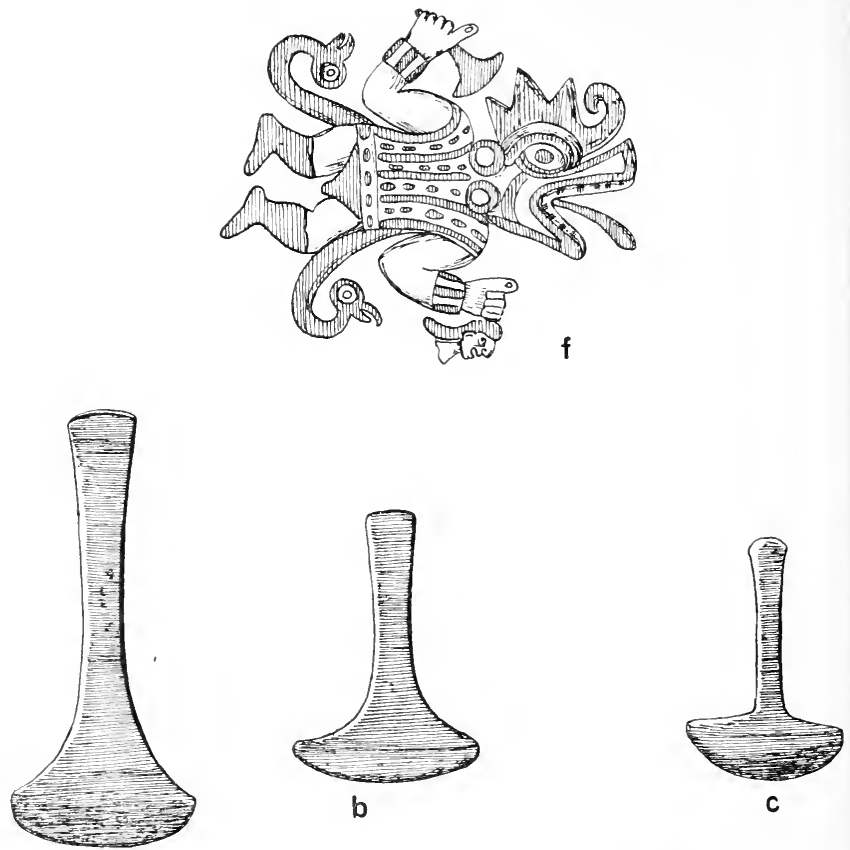

a
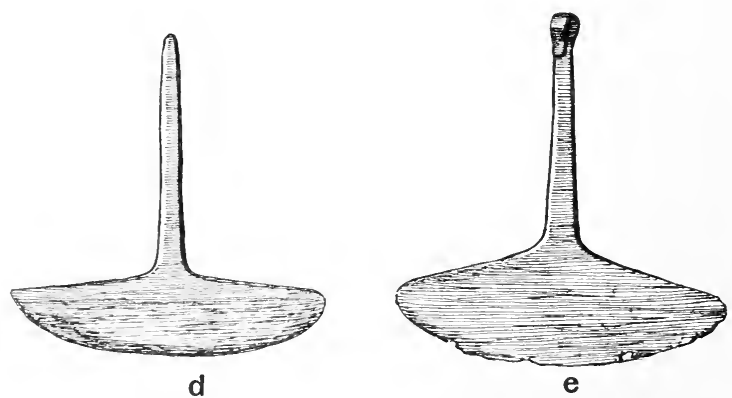

Figs. 31 a - 3 I e. Tumi knives of copper and bronze from the coast of Peru. a. from Lima. (After BAESSLER (I) fig. 53) Sn-o. b.from Chancay (G. M. 2I. I. 4.) Sn-o. c. from Iima. (After BAESsi,er (1) fig. 42). d. from Chuquitanta. (After BAEssier (I) fig. fI). e. from Chancay (G. M. 2 I. I. 7.) sn $4,6 \%$. Fig. 3 I f. Demon with tumi in his hand on a vase from Moche, Peruvian coast. (After UHLE (3) fig. X). 
long to a very early period. The bronze tumi-knife is of a type with international distribution, and which is known from the Inca period.

Those are a few specimens of typological series. To this I would add a note: - When we can show that a type of axe, for instance, has evidently come into existence through the improvement, or, rather, alteration of another type, we may conclude that the former is typologically more recent than the latter. If we come across botly types in archaeological excavations, and have no further details about the circumstances of the find, we cannot assert positively that the typologically more recent is of a more recent period. We have many examples in America of typologically older forms having survived typologically younger ones.

'The 'l-shaped metal axe has scarcely been improved on as an implement. A11 the forms that are derived from it have been weapons and articles of luxury, and it has clearly continued to exist beside the derivative forms.

In spite of the linitations I have called attention to, the typological method should be of great importance in studying the Copper and Bronze Ages in S. America, especially if it is combined with analytic tests and careful excavations.

The typological investigations are very important in comparing the Copper and Bronze Ages of the Old World with those of the New. If, for instance, we find the same shape of socketed axe in the Old World and the New, and do not institute any typological investigations, the conclusions that some ethnologists would, I have no doubt, jump at, are that it nust be a loan. But when we are able to show, typologically, that the socketed axe was an independent invention in America, the loan theory is definitely refuted. 
It is only exact studies of the developments of the forms that enable us to prove to what extent in ethnology we have to deal with parallel development or with loans. Simple as this assertion sounds, it is often lost sight of by theorists. 


\section{CHAPTER VI.}

\section{Copper and Bronze Ages.}

In the foregoing I liave tried to make a list of the types of copper objects mentioned by writers of the time of the Conquest, and of those represented on pottery, woven fabrics, etc. I have also given an account of the copper objects found in such a way that from the circumstances of the finds we can draw some conclusions about their age. I have attempted, moreover, from the geographical distribution of the forms to fix their relative chronology, and have employed the typological method, inasfar as it can contribute to our knowledge of the age of the different forms. Only in passing have I mentioned that certain types have proved, on analysis, to be of pure copper, others of bronze.

I will now try to give a more detailed account of the facts that show that in S. America we can distinguish between an earlier Copper Age and a later Bronze Age, and I will try to base this investigation, apart from analyses, as far as possible on the results at which we have arrived in previous chapters. 
The annexed map I gives us a clear picture of the distribution of pure copper and bronze objects in S. America according to the analyses hitherto published. I have followed the lists drawn up by RIVET \& VERNEAU and DE CREqUiMONTFORT \& RIVET and Jijón y CAAMAÑo, to which I have added a few analyses not known to them, as well as those that are published for the first time in this treatise.

Most of the objects that have been analysed and illustrated, are here reproduced in outline, or in reduced photographs. I have made an exception in the case of the "tincullpas " which Jijón y CAAMAÑo had analysed. Of these only a few characteristic types are reproduced. All of these have the same composition, i. e., they are of pure copper. Though the drawings are in outline, they should suffice to show the shapes of the objects analysed. For a more detailed study, it is always possible to have recourse to the original illustrations in the books cited. What I have aimed at in this list, is a handy résumé of the material analysed and depicted, arranged according to the proportion of tin. All the authors have unfor tunately not given pictures of the objects they have analysed or had analysed, though it stands to reason that a picture should be given of the object analysed, unless, as is sometimes done by RIVET and VERNEAU, the reader is referred to the illustration of another object of identical shape. Otherwise how can we discover whether different forms have a greater proportion of tin than others? It is quite absurd to analyse an indefinite portion of a copper object about which there are no exact statements relative to its find.

It has already been pointed out by BoMAN ${ }^{-1}$ that in Columbia we do not find bronze objects, but only objects of pure copper or of gold mixed with copper. To him we also owe the statement that on the coast of Peru and in Ecuador we find mainly objects of pure copper, and in Bolivia and Argentina mainly objects of bronze. Roughly speaking, this is so. In Ecuador objects of pure copper are much commoner

1) (I). 
than bronze ones. In the maritime country of Peru, especially in the northern part, objects of pure copper predominate. In the district round Cuzco the analyses of $5+$ copper objects has only revealed two not containing tin. In the district round the south of L. 'Titicaca bronze objects still predominate, but objects of pure copper are not all too rare. In $\mathrm{N}$. Argentina and in Chile the majority of objects are of bronze, but still a few ones of pure copper have been found.

FWBANK already assumed that objects of pure copper are older than those of bronze. He writes: - "As the Perurians discovered tin, and employed it somewhat extensively to harden copper, this axe probably dates from a period anterior to that when bronze ones were first made. It is difficult to suppose that such a people would continue to make blades of soft copper when they had tin in abundance to render them so much more efficient. $»^{1}$ )

BomAN $^{2}$ ) assumes that the bronze objects in the maritime country of Peru are Incan, and that objects of pure copper are from an older time. Thus he writes: - "La region des Yuncas semble donc avoir eu, avant l'invasion des Incas, une métallurgie indépendante de celle du Pérou, mais analogue à la métallurgie autochtone de la Colombie et de 1'Équateur préincasique, les piéces contenant de l'étain qu'on trouve dans ces pays, ou du moins l'art de produire cet alliage, y ayant probablement été importés pendant la domination incasique." Jijón y CAAMAÑO ${ }^{3}$ ) also considers this to be probable. If their assumption is correct, copper articles found in the coastal districts of Peru should as a rule be of bronze when they are of types which, by reason of what I have pointed out in previous chapters, we know were in use in Incan times. To test this, I took from the collection of copper tweezers from Pachacamac in the Gothenburg Museum two specimens (Fig. 32 d, e) which in shape and size were exactly like the
1) P. 113 .
2) (I) P. 862 .
3) (2) P. 4 I . 


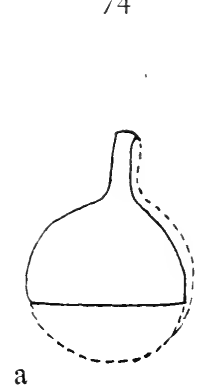

a
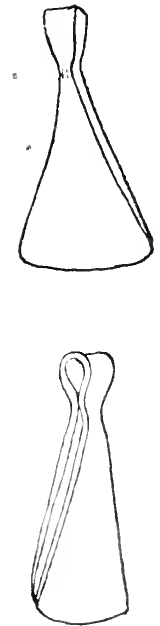

f
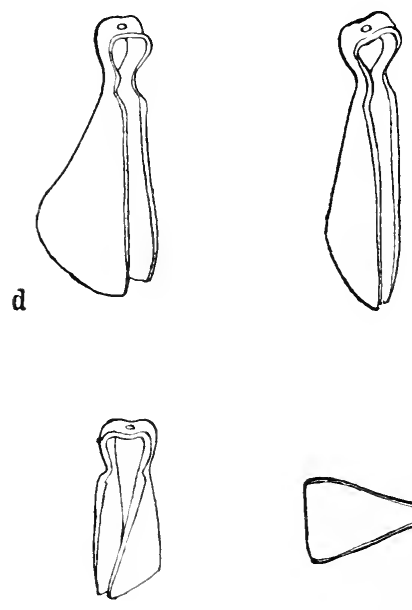

$g$

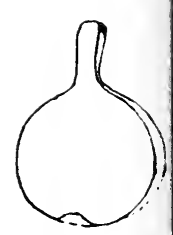

c

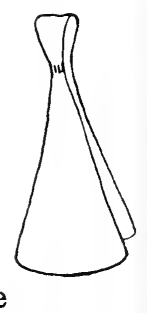

Figs. 32 a -32 h. Tweezers of pure copper and bronze from Peru. $a-f=1 / 1$. a. from Pachacaniac. (G. II. I6. 9. 267) Sn-O; b. from Supe (G. M. 2 I. I. I 4.) Sn-o; c. from Pachacanac. (G. M. I6. 9. 265.) Sn-o; d. from Pachacamac (G. II. I6. 9. 272) Sn-3.4; e. from Pachacamac (G M. I6. 9. 26I) Sn-5.5; f. from Pachacamac (After BALSSI,ER (1) fig. 260) sn-2.75\%; g. from Machu Picchn (.After Mathissox fig. 27) Sn-5.53\%; h. Machu Picchu (After

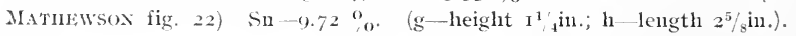


tweezers fornd in Incan Machu Picchu (Fig. 32,g) and had them analysed One proved to contain $3 \cdot+^{\circ}{ }_{0}$, the other $5.5 \%$ of tin. Baessler has analysed a similar pincer (fig. $32 \mathrm{f}$ ) from Pachacamac. It contained $2.75 \%$ of tin.

I then took from the collection three tweezers which, assuming the mussle-shape to be the original one (sec 1). I +9), seemed to be of a typologically older type. (Fig. 32 a. b, c). On analysis they proved to be of pure copper.

The analysis of two Tumi-shaped knives in the collection showed that one (Fig. $3 \mathrm{I}$ e), which is in a form that has been found from the coast of Peru as far as Argentina (see p.5I) was of bronze. The other (Fig. 3I b) which is of a typologically older type, is of pure copper. It is apparently this latter type of Tumi-knife that we see reproduced on earthen vessels which Uhle considers to be pre-Incan (see Fig. 3I f.)

I also had a few tumis from the Musettm für Völkerkunde in Berlin analysed. They all proved to be free from tin. So also did two specimens, which, to judge, by their type, I should have espected to be of bronze. (Fig. 33 e, f).

If we examine the other copper objects from the Peruvian coast that have been analysed, and of which illustrations have been given, we shall find the following. 'The hoe shown in Fig. 33 p contains a little antimony, but no tin. BaEssLER gives a picture of a similar, but smaller one, from Pacasmayo. (Fig. $33 \mathrm{n}$ ). It contains no tin. but $\mathrm{I} .55^{\circ}$ of arsenic. A long, narrow, and somewhat similar object that BAESSLER obtained from 'Trujillo, and which he reproduces (Fig. 330), contained no tin, but $4.03 \%$ of arsenic. A similar hoe (Fig. 331) which Dr. Aluström has analysed for the Gothenburg Insetum, proved to be free from tin, but contained no less than $4.27^{\circ}$ of arsenic.

These hoes, in which the handle was stuck into the point, are not found in Peru save in the coastal regions, nor in Bolivia or Argentina. As far as we can judge, they are not an Incan implement.

BAESSLER has also had a "goldglänzende Scheibe" from 
Fig. s. 33a-.33p. Objects of pure copper from the Peruvian Coast that have been analysed and depicted.

\begin{tabular}{|c|c|c|c|c|c|c|c|c|}
\hline$b-$ & $"$ & $"$ & $"$ & $"$ & 53 & $"$ & $1 / 0$ & $"$ \\
\hline $\mathrm{c}-$ & " & (:. M & 1. 21.1 .4$. & & & Chancay & $1 / 4$ & , \\
\hline$d-$ & $"$ & After & BAESSLER & (I) & fig. & 62, 'Trujillo & $"$ & " \\
\hline$e-$ & $"$ & " & $"$ & $"$ & 6,1 & $"$ & $"$ & , \\
\hline $\mathrm{f}$ - & $"$ & $"$ & $"$ & $"$ & 6.3 & Chnquitanta & $"$ & , \\
\hline$g-I$ & nife & " & " & $"$ & 64, & $"$ & $"$ & $"$ \\
\hline $\mathrm{h}-$ & $"$ & ( $\therefore$. II & I. 2 I. I. 2 . & & & Chancay & $"$ & " \\
\hline$i-1$ & weer & ers & 21. I. I4. & & & Súpe & $1 / 3$ & , \\
\hline$j-$ & ) & " & I6. 9. 265 & & & Pachacannac & $1 / 2$ & $"$ \\
\hline $\mathrm{k}-$ & , & " & 16. 9. 267. & & & " & $"$ & 1) \\
\hline $1-\mathrm{H}$ & & , & 21. I. 6. & & & Chancay & $1 / 6$ & $\begin{array}{l}\mathrm{Sn}-0 . \\
\mathrm{As}-4.27\end{array}$ \\
\hline m- & Hoe? & After & BAESSIER, & (I) $\mathrm{f}$ & fig. & I6, Lima & $1 / 2$ & $\begin{array}{l}\text { Sn-o. } \\
\text { As }-4+3 .\end{array}$ \\
\hline $11-1$ & Hoe & $"$ & $"$ & " & $2 \mathrm{I}$ & Pacasmayo & 16 & $\begin{array}{l}\mathrm{Sn}-0 . \\
\text { As-1.55. }\end{array}$ \\
\hline $\mathrm{O}$ & " & " & $"$ & " & $3^{6}$, & Trujillo & $\mathrm{I} / 4$ & $\begin{array}{l}\mathrm{Sn}-0 . \\
\mathrm{As}-4.03 .\end{array}$ \\
\hline - & " & C. M & I. 21 . I. 5 . & & & Cliancay & $1 / 5$ & $\mathrm{Sn}-0$ \\
\hline
\end{tabular}

(See also figs. I3 D, E, F and fig. 65). 
Trujillo analysed (Fig. 34 g) It contained $9.38 \%$ of tin, but no arsenic. A bronze disk of like type is described by MATHEWsor form the Incan Machu Picchu. As we have seen, disks of this from have had a very wide distribution.

Two knives from Chancay and Chuquitanta (Fig. 33 g, h), of a type only found on the Peruvian coast, and which $I$ have had analysed, proved to contain no tin. On the other hand, another knife, from Súpe (Fig. 3t e), which, to judge from the shape, is possibly post-Columbian, proved to be of bronze.

We thus see that of the copper objects found in the coastal regions of Peru, and which have been analysed, and are reproduced, it is as a rule those which are of types that are also found in the mountain districts, and which were in use in Incan times, that are of bronze. Those types which have only been found in the coastal regions, do not, save in one case. contain tin.

This does not prove, however, that it was not until after the Incan conquest of the coastal regions that the use of bronze came to be known there, as we do not know whether similar types were not used in the mountain districts even in pre-Incan times, and might have spread from there to the coastal regions. It only proves that it was owing to intercourse with the mountain districts that bronze came to be used on the Peruvian coast, and this intercourse, as we know from UHLE's investigations, already existed during Tiahuanaco times. As the traces of Incan influence on the Peruvian coast are much more considerable than those of 'Tiahuanaco, it is, however, to be assumed that the majority of the bronzes found there are from Incan times.

The Bronze Age need not have been continuous on the coast after the Copper Age. We can easily imagine that communications between the mountains and the coast were interruptad at certain times during the Bronze Age, and under such conditions it is possible that, owing to lack of tin, the coastal tribes were for a time forced to return to the use of pure copper. 


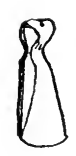

a

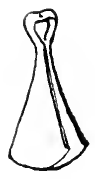

b

$s_{n}-2,75 \quad s_{2}-3.4$

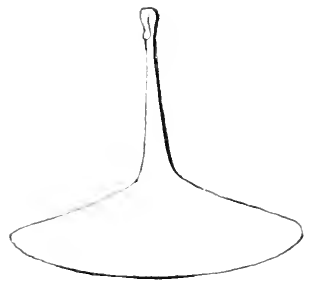

c $S_{22}-4.6$

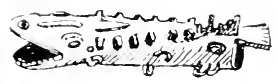

e

$s_{n}-5.6$

f

$S_{2}-7.2$

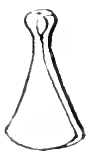

d $s n-5.5$

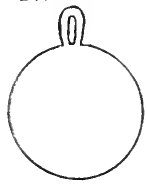

$\mathrm{g}$

$S_{2}-9.38$

ligs. $3+\mathrm{a}-3+\mathrm{g}$. Objects of bronze from the coast of Peru that have been analysed and depicted, arranged according to the percentage of tin.

\begin{tabular}{|c|c|c|}
\hline $\begin{array}{l}\text { a.- Tweezers, } \\
\text { b.- }\end{array}$ & $\begin{array}{l}\text { Pachacamac, } \\
\text { Pacliacanrac, }\end{array}$ & $\begin{array}{l}\text { After BAESSIER, (I) fig. 2rin, } \\
\text { G. MI. I6. 9, 272, }\end{array}$ \\
\hline c.- Tumi, & Chancay, & 2I. I. T, \\
\hline d.- Tweezers, & Pachacamac, & I6. 9.261 \\
\hline c.- Knife, & sípe, & 2I. 1. II, \\
\hline i.-Alligator-Head, & , Huacho, & " $21, \mathrm{I}, \mathrm{I} 5$, \\
\hline - Mirror (?), & Trujill & Ifter B.IESSIER (I) fig. $3 \mathrm{no}$, \\
\hline
\end{tabular}


IFigs. $35 \mathrm{a}-35 \mathrm{~m}$. Objects of pure Copper from Ecuador that have been analysed and depicted. (After RIYET and VerNeAr).

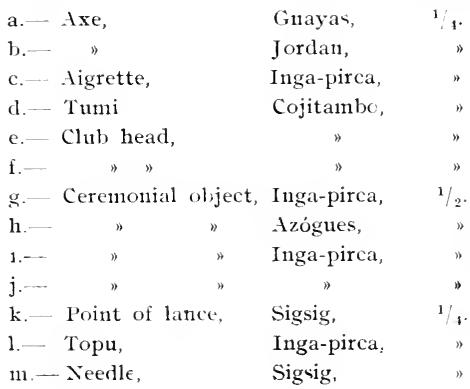


Figs. 36 a -36 o. Objects of pure copper from Ecuador, that have been analysed and depicted. (After RIVET and VERNEAC).

\begin{tabular}{|c|c|}
\hline - Hoe, & $\begin{array}{l}\text { Hacienda la Maravilla, } \\
\text { near Babahoyo }\end{array}$ \\
\hline b.- " , & Puna Vieja, \\
\hline c.-Axe, & Inga-pirca, \\
\hline d.- Gilded copper disk, & Sian Bartoloné, \\
\hline e.- Axe, & Cumbe, \\
\hline f.- $"$, & $"$ \\
\hline g.- "Hache-Monnaie", & P’uná rieja, \\
\hline h.- Socket axe, & Ganchu near Sigsig, \\
\hline i.- Ring, & Huintu! \\
\hline j.-, & sigsig, \\
\hline k. - Axe, & Monay, \\
\hline $1 .-n$, & Inga-pirca, \\
\hline in.-Breastplate, & Riobamba, \\
\hline 1.- Axe, & $\begin{array}{l}\text { Puellaro, } \\
\text { Province of Guayas, }\end{array}$ \\
\hline
\end{tabular}


This would explain the finds of two tumis of pure copper on the Peruvian coast, though they are of types which, for several reasons, we should expect to be of bronze. Still, it is clear that by distinguishing a Copper and a Bronze Age in the coastal regions of Peru we shall obtain an invaluable help in the study of the relative chronology.

RIVET and VERNEAU assume that the bronze objects found in Ecuador are from Incan times. ${ }^{1}$ ) They have had qualitative analyses made af no less than 73 objects of copper. ${ }^{2}$ ) Of these, 13 contained tin. Of 6 Tumi-knives analysed, no less than 5 contained tin. This is of special interest, as the Tumi is one of the objects of metal found throughout the territory occupied by the Incas at the time of the Conquest. The Tumi of pure copper is of a primitive type.

Of the 24 axes of various types with a little hole in them which River and Verneau had analysed, only two are of bronze. This type of axe has a northerly distribution in the old territory of the Incan Empire, and is not found near Cuzco or round L. 'Titicaca. As we have already stated, it is often represented on pottery which, according to UHLE, is from a period much anterior to Incan times. If it is true that bronze was first introduced into Ecuador by the Incas, this type of axe must still have been in use in Incan times. Only one ordinary 'T-shaped axe from Ecuador has been analysed by Rivet and Verneau.

It is of pure copper. The type occurs throughout the territory of the Incan Empire, but yet, as I have pointed out, it must be very old, as most of the other types of axe found here can derive from it. Of simple hoe-blades, three analyses are communicated. One is of bronze. The type occurs through the old territory of the Incan Empire. Four 'T-shaped axes with sharply bent-out edges are analysed. Only one contains tin. This type of axe has been met with from Eicuador to

1) P. $34^{6}$.

2) An object which, apart from tin, contained zinc $(2 \mathrm{I} \%)$ is not included here, being post-Columbian. 


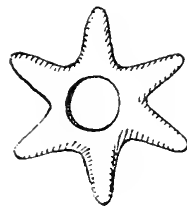

a
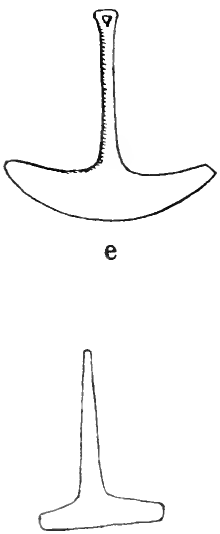

i

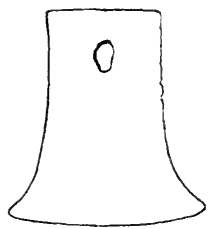

b

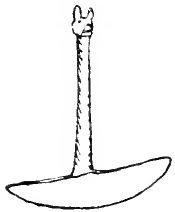

f

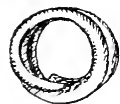

j
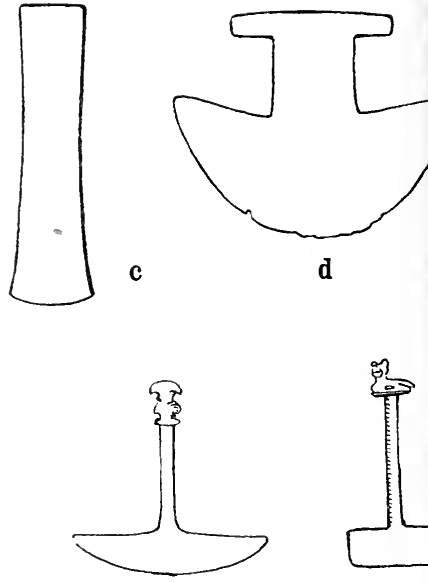

g

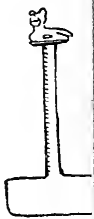

h

Figs. $3 \mathrm{~s} \mathrm{a}-35 \mathrm{k}$. Objects of bronze from Eicnador, that have been analysed ar depicter. (After RIVET and VERNEAC) b-Sn-6.8: d-Sn-6.4. In the remainder th proportion of tin has not been quantitatively determined.

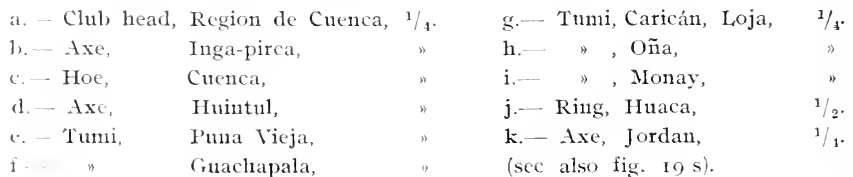


Argentina. 'To judge from the woven fabric shown in Fig. If, it was in use already in Tiahuanaco times. Presumably it was still in use much later, as this seems to be the type of axe referred to in the account of the weapons the Incas had at the time of the Conquest, and as it had a very wide distribution. The two axes with holes for the hafts that have been analysed, proved to be of pure copper. As we have seen, this type of axe is typologically late. Exactly similar axes are unknown, save from Ecuador. A couple of curious show axes of a local type also proved to be of pure copper, as well as two axes that Rivet and Verneau call 'hache-momnaie'. Of the four morning-stars analysed, two are of a type found all the way from Ecuador to Argentina, of bronze, and two of a local type, of pure copper. An awl is of bronze. The point of a lance, of a type we find in the northern part of the territory of the Incan Empire, is also of pure copper. The two Topus analysed proved to be of pure copper. One is of a local type, the other of a type that has been found throughout the territory of the Incan Empire. It closely resembles the Topus shown in Fig. 22 e, but has no hole. Of the other objects analysed, which are all more or less of local types, a ring proved to be of bronze, all the rest of pure copper.

Jijóx y CAAMAÑNO ${ }^{1}$ ) has published no less than 78 quantitative analyses of copper and bronze objects from Ecuador. Of these only $S$ proved to be of bronze. All the "tincullpas", +5 in number, which are of types only found in Ecuador, proved to contain no tin. Nine axes with perforated handles, of the type shown on p. 55, were also of pure copper, as were seven ear-drops, four Topus, a simple hoe, a simple anthropomorphic hoe, a chisel, a languet, and a 'barrita de cobre para fundir'. Of bronze were three ' $\mathrm{T}$-shaped axes, two 'T-shaped axes with semicircular edge, a battle-axe (Fig. 22 d), a star-shaped club-head, and an 'agarradera'.

It is clear that the majority of the objects found in Ecuador that are of local or northern type, are of pure copper, and 
the majority of those that are of types occurring throughout the territory of the Inca Empire, are of bronze. RIVET and VERNEAU ${ }^{1}$ ), like JIJON y CAAMAÑNO${ }^{2}$ ), are therefore of the opinion, as has been mentioned, that bronze was not introduced until Incan times. The last-named puts it as follows: "Siendo la casi totalidad de objetos de bronce, que en el Eicuador se conocen de tipo incaico, o por lo menos peruano, creemos puede tenerse por demostrado, que la aleación dcl cobre y del estaño no se conoció en el Ecuador con anterioridad a la conquista cuzqueña."

It is not possible to say that in Ecuador implements were of bronze, and ornaments of pure copper, for as a rule axes with perforated hafts are of pure copper. It is the local forms, as a rule, that are of pure copper, whether they be implements or ornaments. Consequently we can distinguish, also in Ecuador, between a Copper Age and a Bronze Age.

It is obvious that the bronze objects found in Ecnador are, as a rule, of types that we know were in use in Incan times, and which evidently reached Ecuador from the south. Whether bronze was not known in Ecuador until after the Incan conquest of the country, or whether isolated specimens had already found their way in during the Tiahuanaco period, we are unable, in the present state of our knowledge of the material, to decide with any certainty. The probability. is that the vast majority are from Incan times.

The great question now is, Can we prove that a Copper Age preceded the Bronze Age in the mountain districts of Peru and Bolivia, and in Chile, and in Argentina, as well.

The fact that on the coast of Peru and in Ecuador so many objects of pure copper have been found, whereas such finds are rare in the mountain districts of Peru and Bolivia, and in Argentina, may very well be due to their having been preserved in the former places, and not in the latter. In the loose sand of the Peruvian coastal regions burial finds

1) P. $34^{6}$.

2) (2) P. 23. 
and scattered objects were more easily preserved for posterity than up in the mountains. Where the copper things were not hidden in the ground, a younger generation of Indians would be prone to take possession of them and melt them down.

When a copper object from the coastal regions of Peru occurs in great numbers in museums, but is represented on1y by a few specimens from the mountain districts, this need not signify that it was in common use along the coast, but rare in the mountains. We must remember that most of the museums have incomparably larger collections from the Peruvian coast than from the Peruvian and Bolivian mountains. It is evident, too, that in these latter districts the Bronze Age began much earlier than on the Peruvian coast and in Ecuador, to which regions the knowledge of bronze was conveyed by intercourse with the mountain districts of Bolivia.

BomAN $\left.^{1}\right)^{2}$ ) has already pointed out that the "Crampons", which are found in Tiahuanaco (Fig. 39), and which served to hold blocks of stone together, are of copper that contains no trace of tin. He had two of these "Crampons" analysed. MEAD has had five more analysed; they also proved to be of pure copper. These "Crampons" are the only analysed objects from Tiahuanaco of which we can assert with confidence that they are of an age with the famous ruins. Dr. CourTr, who made excarations at Tiahuanaco, has been kind enough to communicate to me the following: - " "Il y a effectivement à Tiahuanaco des chulpas de différentes époques. Dans celles qui sont contemporaines des fameuses ruines, il n'y a point de bronze du tout. Il y a bien des amulettes en or et en argent natifs, il $\mathrm{y}$ a bien des objets en cuivre natif, mais point bronze." This is of great importance. Thus, in Tiahuanaco, we have presumably also had a

1) (I) P. 859 .

2) The Tiahuanaco cramps have never been metallographically exaninined, but to judge from Bomax's analyses I take it for granted that they were cast, and not hamnered out of the native copper 
Copper Age, from which derive these, the most remarkable of all the ruins in S. America, or even, mayhap, in all America.

With regard to these cramps, we must not omit to point out that for their special purpose pure copper ones were possibly better than bronze ones.

With the exception of the cranps, not one of the 25 objects from 'Tiahuanaco that have been analysed (Fig. 39) proved to be of pure copper.

It is incorrect, of course, to call all the copper objects found at 'Tialnanaco bronzes, as Posnansky ${ }^{1}$ ) has done; he even calls the cramps that on analysis have always proved to be of pure copper, bronzes. Attention should also be drawn to another well-known fact: pottery has been found at Tiahuanaco from different periods, even from Incan times, so that very naturally metal objects from the same time have also been found there.

I have not seen any copper or bronze objects in the pure Tiahuanaco style illustrated, with the possible exception of the famous copper disks of which I made mention in Chapter II. on 1. 32. Posnansixy mentions that he analysed one of them, and says it is of bronze, but as far as I know he has not published the analysis.

In the lower edge of the disk in Fig. I5 a, preserved in the Museum für Völkerkunde in Berlin, there is a nick which shows that some of the metal had been scraped off, presumably for this analysis. The infraction of this precions specimen has been somewhat carelessly carried ont.

Posnansky ${ }^{2}$ ) depicts an animal figure of silver in the 'liahuanaco style. A few gold objects with ornamentation that reminds one of what is regarded as characteristic of 'Tiahuanaco, have been found on the coast of $\mathrm{Peru}^{3}$ ) and on the Island of Koati. ${ }^{4}$ )

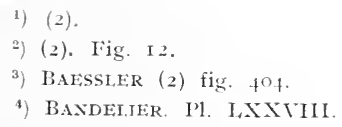




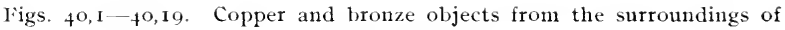
Cuzco, that have been analysed and depicted, arranged according to the percentage of tin.
I. 'Tumi,
Machu I'icchu,
After Mathewsox.
2. Ball,

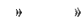
3. Tum1,

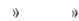
4. Piece of a hoe, Rio Pampaconas,
" Foo'te and Buel. L.
5. Topu, star headed, Machu Picchu,
"Mathewsox.
6. Tumi,
7. Hoe.
8. Axe,
Cuzco,
)
"MFaD
9. Topu,
Machu Picchu,
10. Axe
11. Hoe,
Cuzco,
- Mathewsox.
12. Tumi,
Machu Picchu,
13. Piece of Axe,
1. Needle,
15. Mirror, (?)
16. Large bar,
17. Hoe,
18. Tweezers,
19. Axe,
Erubamba Valley,

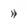
"MLAD.
" Mathewsox.

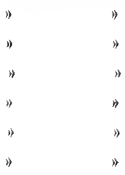
"Foote and BLE1,I.
(For sizes, see MFaD, Matruewson and Footr: \& BuELL). 


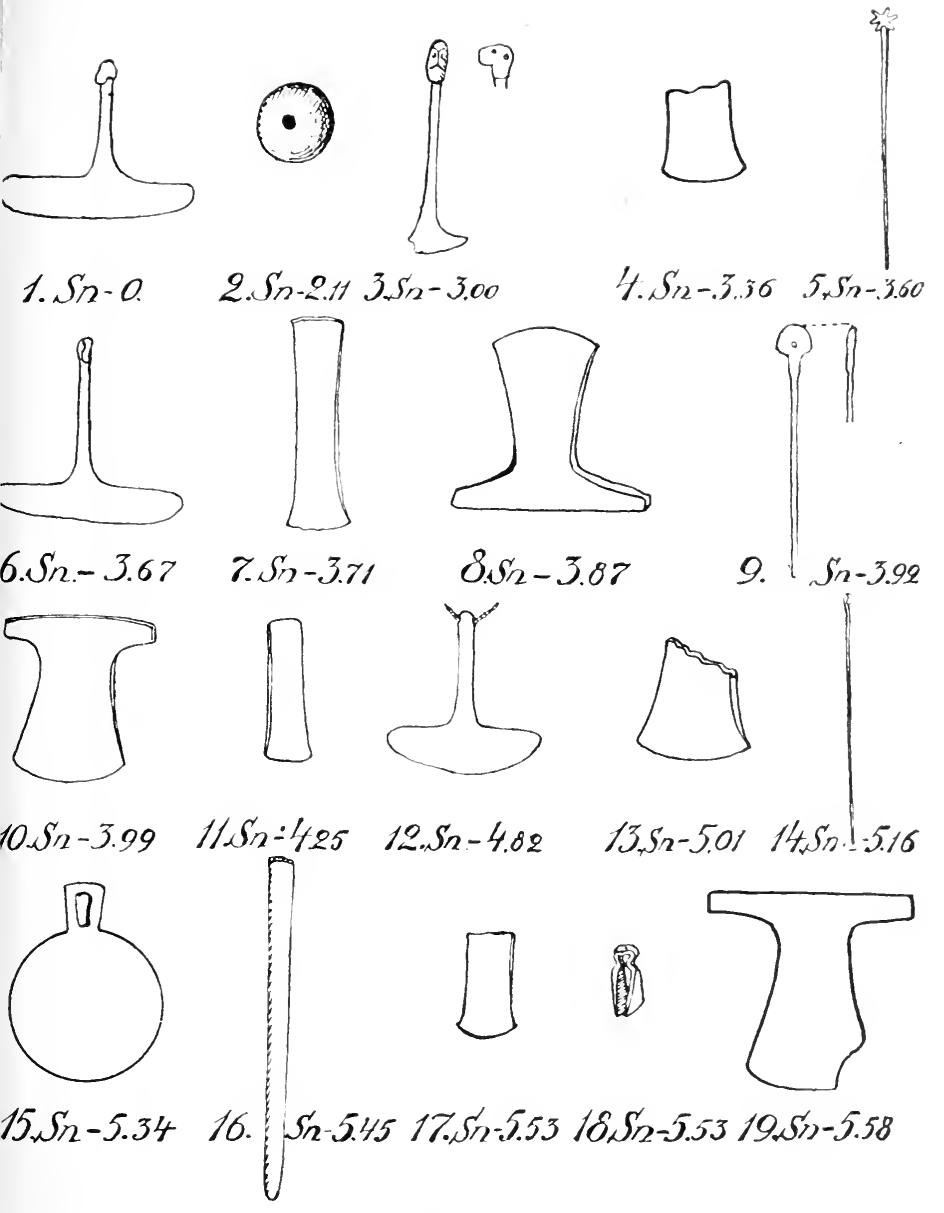

Figs. fo, I- $40,19$. 

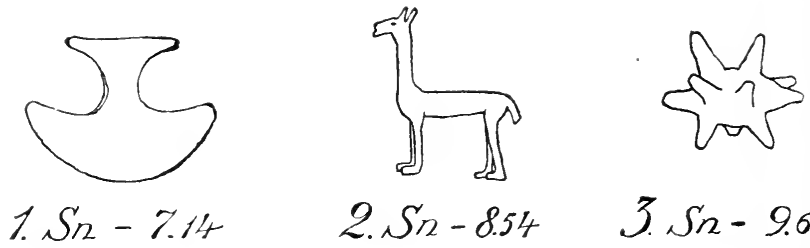

3. $5 n-9.6$
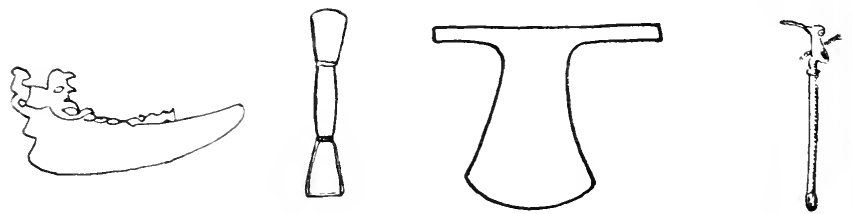

t. $S_{n}-9.395 . S_{n}-9.796 . S_{n}-12.03 \quad 7 . S_{n}-13.45$.

Jigs. $f^{\mathrm{I}} \mathrm{I}-\mathrm{f}_{\mathrm{I}, 7}$. Bronze objects from the surroundings of Cuzco, that have bee analysed and depicted, arranged according to the percentage of tin.

I. Axe,

Cuzco,

After MEAD.

2. Ilama,

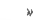

3. Weight for bolas, "

4. Knife,

Machu Picchu,

MATHEWSON.

5. Tweezers, not folded,

6. Axe,

Rio Pampaconas, " Foote and BUEl,

7. Spoon-Tipped handle, Machu Picchu, After Mathewson.

(For sizes, see Mead, Mathewson and Foote \& BCELL). 

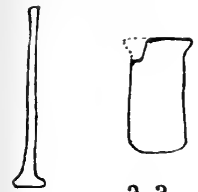

a a

a

$-0$

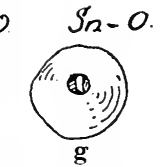

$S_{2}-\not .26$.

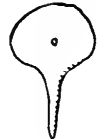

h

$3 n-8.32$

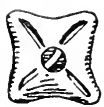

b

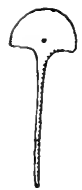

d

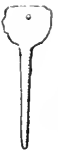

e

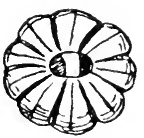

i $S_{n}-2.48 . S_{n}-4 \cdot S_{n}-4.13 . S_{n}-4.3 . S_{n}-5$.

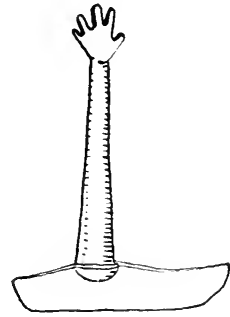

i

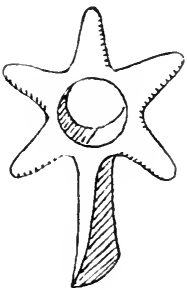

j

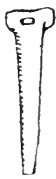

$\mathrm{k}$

$$
S_{n}-9.12 . \quad S_{n}-10.02 . S_{2}-17.78
$$

igs. $42 \mathrm{a}-t^{2} \mathrm{k}$. Objects of pure copper and bronze from the Titicaca district specially Titicaca I., that have been analysed and depicted, arranged according to the percentage of tin.
a.- Chisel,
Titicaca I.,
After MEAD.
aa.- - Axe,
Copacabana,
M. f. V. B. V. A. I 279 I C, ${ }^{1}{ }^{\prime}$.
b.- Weight for bolas, Titicaca I., After MEAD.
c.- Needle,
d.- Topu,
e.- "
f.- Weight for bolas,
g.- "
h-Topu,
i. - Tumi,
j.- Clublead, with hatchet "
k.- Bar in Axe-shape, Huachu, Omasuyu, M. f.V. B.V.A. I 2672 b. $1 / 5$ (For sizes sce also MEAD). 
Figs. $43, I-43,2$ I. Objects of pure copper and bronze from Argentina that have been analysed and depicted, arranged according to the percentage of tin.

I. T-shaped axe with double projections, Calchaqui, After SÁxchez DiAz,

I1). " " " La Toma, M. f. V. B. V. C. 1658

Ic. " " "

2. Axe, La Paya,

2b. Cramp, Andalgala

3. Chisel, Tastil,

4. Chisel?, Musquin,

5. Tool, Belén,

6. Part of bracelet, Huasasayo,

7. Hoe,

8. Bell,

Fuerte Quemado,

Casabindo,

9. Axe,

Belén,

Io. Small disk,

La Paya,

I1. Chisel?,

Catamarca,

1 2. Hoe,

Belén,

13. Axe,

Calchaqui,

14. Disk (Diam. 2 cm.), Pampa Grande,

I5. " (" $20 \mathrm{~cm}$.$) , Chicoana (Salta),$

I6. " (" $26 \mathrm{~cm}$.), Pampa Grande,

I 7 " "Tinti,

Is. " (Diam. I9 cm.), Luracatao (Salta),

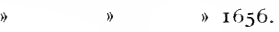

After BonaN

(I), fig. $14,1 / 6$

II. f. V. B. V. A. 4057 .

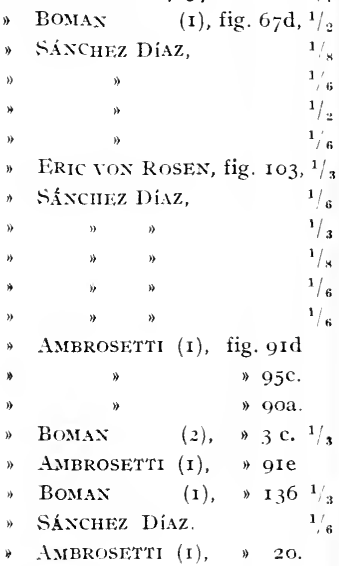

19. Pendant?

Pucara de Rinconada,

20. Axe,

Calchaqui,

2I. Axe,

San Carlos,

* Axbrosetrí (I), " 20. 
Figs. H,I-4 - 22. Objects of bronze from Argentina that have been analysed and depicted, arranged according to the percentage of tin.

\begin{tabular}{|c|c|c|c|c|}
\hline I. & Bell, & La Paya, & After & BOMAx, (I), fig. If, \\
\hline 2. & Chisel, & Morohuasi, & $"$ & $" \Rightarrow, " 56 \mathrm{c}$ \\
\hline 3. & Bell, & 'Tinogasta, & 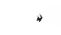 & SÁxchez DiAz, \\
\hline 4 . & Knuckleduster, & Jujuy, & $"$ & $"$ \\
\hline 5. & Disk (Diam. 27.5), & Santa Maria, & $"$ & AMBrosetTt (I), fig. $9 \mathrm{Ib}$. \\
\hline 6. & Axe (Size not stated), & " & $"$ & ") 24 \\
\hline 7 . & Hoe, & Belén, & $"$ & SÁxchez Dítz, \\
\hline s. & Bell, & San Juan, & $"$ & DEBENEDETTI (2), fig. $97^{1 / 6}$ \\
\hline 9. & Axe, & Calchacui, & $"$ & SAXCHEZ DÍAZ, \\
\hline Io. & $"$ & Andalgala, & $"$ & $"$ \\
\hline II. & Hoe, & Belén, & $"$ & " \\
\hline 12. & Ceremonial axe, & Musquin, & $"$ & $"$ \\
\hline I 3. & Axe (Size not stated), & , Tolombon, & $"$ & AMBrosetti $(\mathbf{I})$, fig. 20. \\
\hline 14. & $"$ & Calchaqui, & $"$ & SAXCHEZ DIAZ, \\
\hline I 5 . & Chisel, & Morohuasi, & $"$ & ERIC VON ROSEN, fig. $206,{ }^{1}$ \\
\hline 16. & $"$ & La Paya, & $"$ & SAXCHEZ DIAZ, \\
\hline 17. & $\begin{array}{l}\text { Axe with semicircular } \\
\text { edge, }\end{array}$ & Ir Jujuy, & $"$ & " \\
\hline 18. & Disk (Size not stated) & 1), Tolonibon, & $"$ & AMbrosettr (r), fig. 87 . \\
\hline I9. & Knuckleduster, & Santa Maria, & $"$ & SÁxchez DiAz, \\
\hline 20. & Ball, & La Paya, & $"$ & (I), fig. $\mathrm{I}_{3} \mathrm{n}^{\mathrm{I}}$ \\
\hline $2 \mathrm{I}$. & Chisel, & $"$ & $"$ & (I), fig. I $3 \mathrm{~b}, 1 / 6$ \\
\hline 22. & Bracelet, & Quebrada del Toro, & $\Rightarrow$ & (I), fig. $54,1 /$ \\
\hline
\end{tabular}


Only one object was found at Machu Picchu that proved when analysed, to be of pure copper. It is a Tumi (fig.40, I). As it is of a typologically late form, and no remains of preIncan art have been found at Machu Picchu, I assume that this pure copper Tumi is not older than the bronzes of the same place. But it must be pointed out that the Tumi in question is not one of the objects found by EATON in his careful excavations, but was obtained from grave-plundering Indians who were afterwards let loose among the localities of the finds.

Of other objects analysed from the surroundings of Cuzco, 23 proved to be of bronze, and only one, a little human figure, of pure copper. It is not illustrated. All the copper objects found by me in the Chulparegion have when analysed proved to be of bronze (See p. I63).

On 'Titicaca Island 7 objects of pure copper were found. Among them, curiously enough, were no less than 3 chisels. It would, I think, have been very extraordinary if in these parts, where tin was in the vicinity, they had generally made their chisels of pure copper after becoming acquainted with bronze. There is therefore, in my opinion, much to favour the belief that these are from a Copper Age that here preceded the Bronze Age. At Copacabana was also found a $T$-shaped axe (Fig. +2 aa) which on analysis, proved to be of pure copper.

Very interesting is the find, mentioned above, of a piece of a pure copper band in Caipipendi. Other finds at the same place show that the Indians there employed at the time stone axes of the type that RIVET and VERNAU call 'haches simples néolithiques'. 'The ornamentation on the Pottery is not painted, but scratched. There were no handles on the earthen vessels. The find of sea-shells (Pecten) shows that the Indians at Caipipendi had intercourse with Indians at the coast, probably the Pacific.

If we now turn to Argentina, we shall find in Figs. 43,44 the objects that have been analysed and depicted, arranged 
according to the proportion of tin, which varies very greatly. Of the analysed objects found in Argentina, only 6 proved to be of pure copper. Had the objects to be analysed been chosen more systematically, and such objects selected as were found with non-Incan pottery, more objects of pure copper would presumably have been revealed. Still, it is worth noting that five of the objects from Argentina that proved to be of pure copper, are implements.

A peculiarity for Argentina is undoubtedly that there we have local forms that are of bronze, whereas these are found only exceptionally on the Peruvian coast and in Eicnador. How is it to be explained that Argentina should have had an independent Bronze Age, while the Peruvian coast and Ecuador had not? It may be because they made an earlier acquaintance with bronze in Argentina than in Ecuador or on the coast of Peru, and that possibly, as we shall see later on, they were not dependent on the Bolivian tin.

Another peculiarity for Argentina, especially for Catamarca, is bronzes containing less than $1 / 2{ }^{\circ}$ of tin. From the tables below we can see where these were found.

\section{Objects of Bronze containing less than $1 / 2{ }^{\circ}$ of tin.}

Fuerte Quemado,
Catamarca

Belén, Catamarca
Chisel

'Hache ceremoniclle' 0.20 \% . RIVET and DE CRÉ-

Huasayaco, Catamarca Fragment of a bracelet $0.24 \%$.

Musquin, Catanarca Spatula $\quad 0.17{ }^{0}{ }_{0}$. .

QUT-MONTFORT.

Andalgala near s:a

"Cranp." Trace. See fig $2 \mathrm{~A}$

IIaria, Catamarca

The small admixtures of tin in question cannot have been purposely added. They may derive from impurities in the copper ore. Copper ore has been found in the Old World with a small admixture of tin. Thus MIONTEI IUS ${ }^{1}$ ) writes:

1) (I), P. 449 . 
"Wenn der Zinngehalt klein ist, kann es sehr schwer sein, zu sagen, ob er absichtlich ist oder nicht. Die meisten Kupfererze enthalten gar kein Zinn. In anderen findet man eine kleine Quantität von diesem Metall. Englisches Kupfer kann 0.20 Proc. Zinn enthalten, und in südöstlichen Spanien giebt es Kupfererze mit 0.4o bis 0.50 Proc. Zinn. Ein Zinngehalt von ungefähr $0.5^{\circ}$ Proc. kann folglich natürlich sein. Wenn der Gehalt höher ist, muss er als absichtlich betrachtet werden - falls man nicht andere Kupfergruben kennen lemen sollte, wo das Kupfer mehr Zinn enthält."

According to Bomas, native copper from Corocoro occasionally contains traces of tin. ${ }^{1}$ ) A piece of native copper that I obtained when I visited Corocoro in I904, showed, however, no trace of tin when analysed, and $M \mathrm{EAD}^{2}$ ) says that Mr. ATWATER, who is a specialist in copper ores from Bolivia, and who has made some five hundred essays and analyses of Bolivian copper ores, has never found tin in them.

If in these objects of copper with traces of tin the tin is due to impurity in the copper ore, these objects presumably belong to the Copper Age. It is to be observed that the implements Nos. 4 and 5 depicted in Fig. 43 , are of peculiar local forms, which are unknown from the Inca period. Of special interest is that among these objects is a cramp similar to those from 'Tíahuanaco which on being analysed have always proved to be of pure copper. This cramp, which was found by the German traveller HerrMAN, is kept in the Museum für Völkerkunde in Berlin.

It is, however, possible to explain the low percentage of tin in these objects in another way. It may be no mere chance that these objects with such a low percentage of tin

1) "Lixceptionellement, le cuivre natif de Corocoro (Bolivie) contient en très petites quantités d'étain, suivant un renseignment que m'ont donné MM. Morin fréres, lesquels ont analysé de nombreux échantillons de (uivre de ce pays." (x), "p. 865 .

It should also be noted that BARBA says that cassiterite at Carabuco was found together with copper ore. I'ol. 32.

2) I'. 49 . 


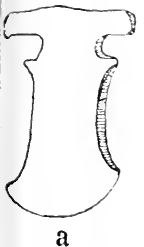

$\int n-O$

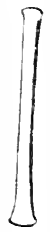

$\mathrm{e}$

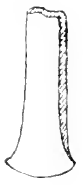

b

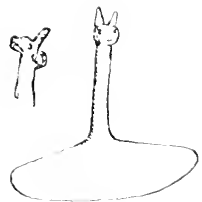

$\mathrm{c}$

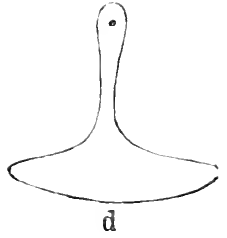

$\sin -4$

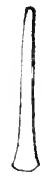

$\mathrm{f}$

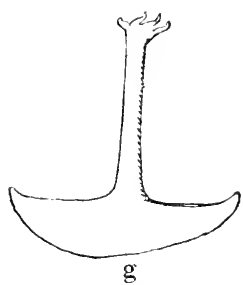

$\int n-P$

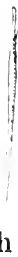

h
Sn- 5 .
$S n-6$

$S n-P$

Figs. 45 a - h. (Ohjects of pure copper and bronze from chile hat have been analysed and depicted. $I$ '. indicates that the object contains tin, lnt that this has not been quantitatively determined.
a. - Axe, Atacana Chile, After FwB.iNk, l'l. VIII, ${ }^{1}{ }_{6}$.
b.- Hoe, Rio IIaipu,
c.- Tumi, Bay of Chacota, "Brakis, P. 289, fig. 1 $2,{ }^{1} 2$.
11.- " " SgCiek (2), " fig. 68, 3 , .
e.-Chisel, Rio Maipu,
f.- "
g.- Tumi,
h.- Aw1, Ariea,

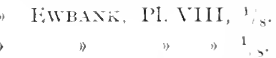 " " 1/. I'. $\mathrm{X}, \quad{ }^{1}, \mathrm{f}$. 
are found, so to speak, in the periphery of the Inca Empire. The low percentage can be so explained, that old broken copper found in the ground was melted down with some old broken bronze, and implements, etc., made from this. In remote parts they often had to take what they could get. It must also be remembered that through repeated recasting of a bronze the admixture of tin continually diminishes, some of the tin being lost each time. If this explanation is correct, these objects of copper with a very low percentage of tin date from the Bronze Age.

It is probable that tin, when it occurs in a larger proportion than I to $2 \%$, always has been intentionally added. The eminent metallurgist Mathewson appears to take it for granted that the tin in the bronzes he examined was intentionally added. They contained from $2 . \mathrm{II} \%$ to $\mathrm{I} 3.45 \%$ of tin. Mathewson has also pointed out that the bronzes from Nachu Picchu are very free from impurities. By reason of the find of bits of pure tin in Machu Picchu, he considers it probable that the Indians used the like for mixing with their copper.

The copper objects from Chile that have been analysed are II in number: of these 9 have proved to be of bronze, and two of pure copper. These two are implements, an axe and the blade of a hoe. Most interesting is that the axe is a $T$-shaped one with double projections. Among the six copper objects from Argentina which on analysis proved to be of pure copper, there are also three axes of this type. These are the only specimens of this kind of axefrom Argentina that have been analysed, and it is possible that in them we have a form characteristic of the Copper Age. The type is a development of the ordinary 'T-shaped axe, but it may be typologically older than the whole series of formis of axes depicted in Fig. 29, which can evidently derive from the 'T-shaped axe.

We have seen that in Eicuador and in the coastal regions of Peru the Bronze Age has undoubtedly been preceded by 
a Copper Age. It is also evident that this Bronze Age reached the Peruvian coast-land and Ecuador from the Bolivian and Peruvian mountain districts, the characteristic mountain forms found there being, as we have pointed out, of bronze, whereas the local forms are generally of pure copper. In the mountains of Peru and Bolivia, and in Argentina, and Chile there are, as we have seen, numerous bronze objects, but al o some pure copper ones, the majority being found round I. Titicaca. And even if these should not be regarded as proving that the Bronze Age in the mountains was preceded by a Copper Age, we must nevertheless realize that it is not reasonable to assume that in the mountain regions there was a direct transition from a stone Age to a Bronze.

Bronze must have been invented by a race that used pure copper and understood the art of casting, and as the invention did not originate on the coast or in Ecuador, it must come from the mountain tracts where there was a supply of tin. Here too, the Bronze Age must inevitably have been preceded by a Copper Age, assuming of course that bronze was invented by the Indians themselves, and did not in some mysterious manner find its way in from the Old World. I shall return to this problem later.

A Copper Age need not necessarily, of course, have preceded a Bronze Age throughout Bolivia, the Peruvian mountains, Argentina, and Chile. The area of the Copper Age may in certain parts have been much more restricted than that of the Bronze Age. It is even probable that a number of districts did not learn the use of copper until during the Bronze Age, but it cannot have been in such a district that the invention of bronze originated; it must have been in a district where the art of casting pure copper was understood before bronze was known.

At present it is impossible to say when the Bronze Age began in the mountains. The oldest Tiahuanaco seems to be from the Copper Age. The Incan times were within the Bronze Age. In the Chulpas we find exclusively bronze objects. It 
therefore appears as if the Bronze Age must have begun at some period intermediate between the Incan times and the building of Tiahuanaco. If PosNansky is right in saying that the famous disk (Fig. I5 a) is of bronze, then bronze must have been known when the influence of the Tiahuanaco culture made itself felt. The colour of the disk also points to the metal not being of pure copper, and it is from a locality where copper mixed with arsenic is very rare. 'This also explains how it is that all the 'copper' objects found at Tiahuanaco, with the exception of the cramps, have proved to be of bronze when analysed. The same holds good of the quaint human figures (Fig. $28 \mathrm{c}$ ) from there. I should perhaps add that the copper objects (fig. 62). I found in the culture deposits of the Mizque Valley, which have a ceramic art that is strongly influenced by the Tiahuanaco style ${ }^{1}$, have proved, inasfar as they have been analysed, to be of bronze. But it is not absolutely certain that these bronze objects are of the same period as the pottery found at the dwelling-places.

There is, after all, nothing impossible in the fact that the Indians, who could achieve such architecture as liahuanaco, should have invented bronze, especially as it was not far from that spot that there existed the only plentiful supplies of tin in S. America.

If bronze was known in the later Tiahnanaco period, it is most prudent not to assume for certain that it was first through the Incas that the knowledge of bronze was conveyed to the Indians on the coast of Peru and in Ecuador, but rather that it already took place when the influence of the 'Tiahuanaco culture made itself felt. We have seen that on the Pernvian coast has been found a woven fabric in the 'liahuanaco style on which are represented types of axes that seen to belong to the mountain culture.

It is of course possible that the Indians round L. Titicaca, and also those in Argentina, were living in a Bronze

1) NORDEASKIOIL (4) 
Age while those in the coastal regions of Peru and in Ecuador were living in a Copper Age. But that this should have continued for a considerable time postulates a very insignificant commercial interconrse between the stanniferons mountains round $I_{1}$. 'Titicaca and the coast-land, or Licuador, where there was no tin. The Indians of the coast cannot have had commercial interconrse with those of the monntains for any considerable time withont beconing acquainted with bronze, if it was known there.

'To obtain a definitive solution of this problen it is necessary, above all, that throughout the west of $S$. America systematic excavations be undertaken, similar to those made by EAton at Machu Picchu. It is the finds of copper objects made at such excarations that must first be analysed. It would of course be of the greatest interest if some copper objects found in graves on the Pernvian coast with pottery or textiles in Tiahuanaco style, could be analysed; but I do not know whether any such objects are to be found in any musenm, i. e. any that are preserved with exact details about the circumstances of the finds. Very welcone too would be the analyses of copper objects from graves in Argentina, where the ceramic art is of an exclusively local
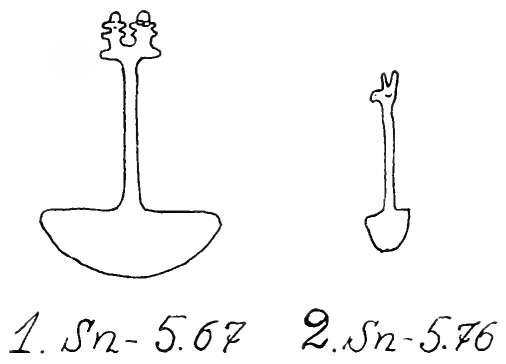

Figs $f^{6,1}, 2$. Tumis of bronze from Cajamarca, northern Peru. (After MEAD). 
IOS

type. It would be especially valuable to have some analyses of copper objects found in urns containing child bodies which are so characteristic of those parts. And, as I remarked, it would be interesting to have the copper objects analysed which BRTCH found in his careful excavations at Hualfin. 


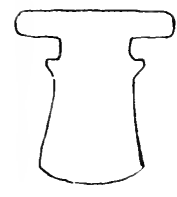

a

$S^{\prime} n-6.15$

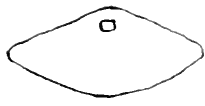

b

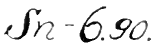

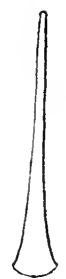

c

Figs. 47 a -47 c. Objects of bronze from Tarija, Bolivia. a-Axe M. f. V. B. V. A. 15625). Ca: ${ }^{1}{ }_{1}$. b-Bronze disk (After vox Rosex, fig. 336). ${ }^{1}{ }_{1}$. c-Chisel (After rox ROSEA, fig. 335.) ${ }^{1 / 6}{ }_{6}$.

\section{CHAPTER VII.}

\section{Why Tin was mixed with the Copper.}

It is evident, as we have already mentioned, that tin was intentionally mixed with copper in a considerable part of S. America. Judging by our European conception of different kinds of bronze, the mixture of tin and copper in the $s$. American bronzes that have been analysed was very capriciously composed. Thus, Borrax has pointed out that it is not the cutting implenents that contained a specially high percentage of tin, and that very often these implements which one might assume should have been harder than the ornaments, contain less tin than the latter. (See Figs. $+3,+4$ ). He writes: "Les proportions d'étain sont si variables, que l'on peut conclure que les Indiens en question ignoraient l'art de graduer l'alliage selon la destination des objets. C'est empiriquement et an juger qu'ils ajoutaient l'étain, parce que l'expérience leur arait enseigné cette manière de durcir le métal. $\left.{ }^{1}\right)$

1) (I) p. 868 . 
The material of analyses at Bomax's disposal embraced bronzes from a huge area and, undoubtedly, from a long period.

It is the American metallurgist Mathewson's great merit to have pointed out that the $S$. American Indians may purposely have alloyed tin with copper in different proportions for different purposes, but that they proceeded from points of view that differ from those usually imagined. MATHEWSon has examined numerous bronzes found by Binghar at Machu Picchu, and concludes that the Indians of that place presumably mixed less tin in the implements than we might have expected, in order to be able to hammer them the more easily. ${ }^{1}$ ) 'The objects were hammered hot or red-hot, as MATHEWSON has verified by microscopic examination.

In order to discover to what extent the hardness of the bronze was due to the proportion of tin, or to the treatment to which it had been subjected, I consulted Mr. A. HULTGRen, and asked him to examine the hardness of some S. American bronzes with different proportions of tin. 'The results of Mr. HulTGREN's tests are added in a special appendix, and I will only add a few comments here which may be of interest for the archaeological problems we are dealing with. ${ }^{2}$ )

1) EWBANK (p. II5) was of the sane opinion. Thus, as early as I 855 he wrote: "Peruvian cutting tools of bronze which $I$ have met with have been comparatively little hardened, the proportions of tin not exceeding from two to three percent. Now, why was this? Because old workmen preferred keeping them so far malleable that they might be readily thinned by the hammer, and have only the finishing-edge put on by the hone, to making them brittle and hard, when nothing but tedious abrasions could restore or bring up a jagged or broken blade."

$\left.{ }^{2}\right)$ This examination was suggested to me in the first place by SEIER'S important examination of a hammered copper axe from Mexicc. By means of the scleroscope, SELER (2) had the hardness of this axe examined, both in the condition in which it was found and after it had been annealed. 
I also had three axes made, A, B, and $\mathcal{C}$, of which $A$ was of pure copper, B contained $5 \%$ of tin, and C Io \% of tin. When they were cast, it turned ont that the metal in the copper axe, especially, was very blistery.

The liardness of these axes was then tested by $\mathrm{Mr}$ Hultgren with a BRINELL press, an instrument that is considered by metallurgists to be nutch nore reliable than the scleroscope. The hardness was first measured after the casting, then after cold-hanmering to different thicknesses, and lastly when the axes, after having been hammered, had again been annealed and the effect of the cold hammering removed.

It was found that the pure copper could be cold-hammered up to a hardness of $\mathrm{x} 2 \mathrm{~S}$, the hardness after annealing being about $5^{\circ}$.

The $5 \%$ bronze conld be cold-hammered up to a hardness of 203 , the hardness after annealing being about 70 .

The so \% bronze could be cold-hammered up to a hardness of 228 , the hardness after annealing being about 85 .

From this we see that the hardness of copper cannot be increased by the admixture of Io $\%$ of tin as much as pure copper can be by hanmering. By the addition of tin the copper has acquired a quality which permits of its hardness being still further augmented by hammering.

The advantage of adding Io \% of tin to the copper instead $5 \%$, was very small when the hardness was to be increased by hammering.

The hardness was then compared with that of anmealed copper. The axe is of practically pure copper. The result was as follows:

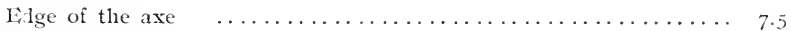

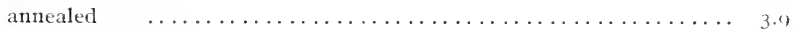

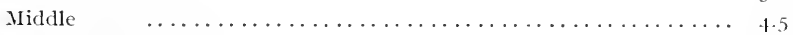

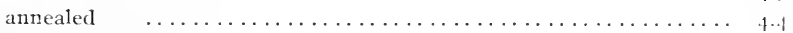

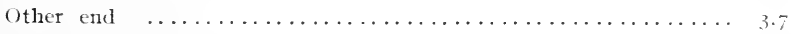

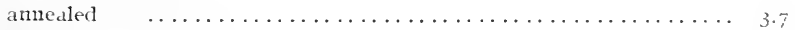

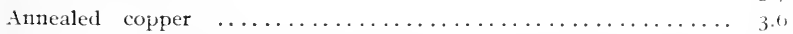

Clearly enongh it is mainly tha edge of the axe where the hardness had leen enlanced by the treatment. 
If we turn to the S. American bronzes that have been examined, it is evident that the Indians increased their hardness very much by hammering. (See Appendix A). But they did not increase the hardness as much as might have been done. The art of cold-hammering was not sufficiently utilized.

From the figures in the Appendix $\mathrm{A}$ we can see that a more stanniferous bronze is not necessarily harder than one containing less tin. The latter can be rendered harder than the former by being hammered. An examination would presumably reveal the fact that ornaments, even if they are occasionally of a bronze with a larger proportion of tin than that used in implements, are nevertheless not so hard. This seems to follow, too, from the tests of hardness with the scleroscope that MATHEwson made on the bronzes from Nachu Picchu. What value he assigns to his tests of hardness does not appear from his work, seeing that he makes no comparison between the figures he obtained.

The following degress of hardness were obtained by MATHEWSON:

\section{object}

No.

I4 Tumi (see Fig. 4o, 6)

6 Blade of hoe (Fig. fo, $^{\circ}$ )

I I 'Topu (Fig. to, 9)

Is Pin (Fig. 40, If)

20 Object, purpose unknown

(Fig. +o, I6)

$\begin{array}{cccc} & \text { Hardness } & \% \text { of } \\ \text { Haft, } & & \text { Blad } & \\ \text { If } & & 27 & \left.3.67^{1}\right) \\ \text { I5 } & 24 & 30 & 3.7 \text { I } \\ & \text { I4 to I8 } & & 3.92 \\ \text { 2I } & \text { I8 } & \text { I5 } & 5.16\end{array}$

I 8 to 25

5.45

I6 Piece of hoe-blade (Fig. 4o, I 7 ) I 5 to 16

2I Piece of metal

9 to IO

2 Spoon-tipped handle (Fig. 4 I,7) I 4 to I5, 32 to 35 I3.45

1) Soft annealed alloys of this composition give a hardness number below io. 
MATHEWSON points ont furthermore that among the bronzes from Machu Picchu examined by him, it was apparently the hardest to cast that contained most tin, i. e. the finer ornaments. He is of opinion that the Indians added more tin than usual when they wanted to cast such objects.

I think it is at present very difficult to decide whether MATHEWSON was right in assuming that more tin was added to the copper when difficult figures were to be cast, for there are comparatively few analyses of the finer metal work which, according to MATHEWSON, should be of bronze with a high percentage of tin. Investigators have very naturally been averse from damaging these finer pieces of work by analysing them.

The Table below neither refutes nor supports MIATHEwson's theory. It includes all the objects from Argentina, Peru, Bolivia, and Ecuador that have been analysed and have proved to contain more than ro $\%$ of tin. They are but 23 , of which 9 are implements or weapons $\left.{ }^{1}\right)$. Unfortunately we have pictures of only some of the bronze ornaments with a high percentage of tin, and it cannot be said of all of these that they must have been hard to cast.

1) To these must be added a couple of objects from Argentina called 'Fragment très oxydé' and 'objet indéterminé'. 
I I 4

Bronze Objects from Argentina, Peru, Bolivia, and Ecuador containing more than $10 \%$ of tin.

Place of Find

Chimbote

Palasgache

Rio Pampaconas

Machu Picchu

Tiahuanaco

))

Titicaca I.

)>

Copacabana

Huata

Yura

$\gg$

Omasuyu

Sorata

Pulquina Mizque

Sara

E1 Angel, Ecuador

La Paya

» $\gg$
》)

Golgata

La Paya

Ira Rioja
Object

Group of figures I3.2I MEAD.

Pin

Axe (Fig. 4I, 6) I2.03 Foote \& BUELI.

Spatula? (Spoon)

(Fig. 4I, 7) I3.45 Mathiswson.

'Topu

I2.IO MEAD.

Pendeloque

$$
\text { (Fig. 39, I3) I0.59 " }
$$

Axe (Fig. 42 j) I0.02"

Topu

I0.62 "

" I 2.68 "

"

"

Disk

10.50 "

IO.2I BOMAN (I).

Axshaped object $\quad$ I $7.7^{S}$ (See Fig. $2 \mathrm{E}$ )

Head of Club II.42 FORBES (I).

Axe

Disk

I3.42 See p. I67

T-shaped axe

I0.34 "

I3.36 JiJÓN Y CAAMAÑO (2).

Chisel (Fig. 44, 2I) I3.52 Boman (I).

"

55.6oAmbrosetTt (3).

"

30.15

Bracelet(Fig. 44,22) I4.I3 BOMAN (I).

Disk

Disk
I7.-AMbrosetTti(3). I6.53 ${ }^{1}$ ) MORENO. 
ligss. $f^{x, 1}-48,18$. (Sice p. 116). Objects of bronze from the boundary districts of Peru and Bolivia tliat have been analysed. (111 collected by the author). ${ }^{1} \cdot 4$.

\begin{tabular}{|c|c|c|c|c|c|c|}
\hline I. & 'Tumi, & Quiaca, & R. $\mathrm{NI}$. & o6. & 1. & 177. \\
\hline 2. & Topu, & Queara, & $"$ & $"$ & $"$ & 357 . \\
\hline 3. & " & Pelechuco, & $"$ & $"$ & $"$ & 319. \\
\hline 4. & Axe, & Pata, & $"$ & $"$ & $"$ & 160. \\
\hline 5. & Tumi, & Ollachea, & $"$ & $"$ & $"$ & 176. \\
\hline b. & Topu. & Queara, & $"$ & $"$ & $"$ & $35^{8}$. \\
\hline 7 . & Tumi, & Ollachea, & " & $"$ & $"$ & 175. \\
\hline 8. & Axe, & Quiaca, & $"$ & $"$ & " & 165. \\
\hline 9 . & Topu, & Corani, & 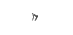 & $"$ & $"$ & 521. \\
\hline Io. & $"$ & Pelechuco, & $"$ & $"$ & $"$ & 316. \\
\hline Ir. & Axe, & Clunquesani, & , " & $"$ & $"$ & 168. \\
\hline 12. & 'Topu, & Queara, & $"$ & $\Rightarrow$ & $"$ & $34^{8}$ \\
\hline I 3. & $"$ & $"$ & $"$ & $"$ & $"$ & 399. \\
\hline$I_{4}$. & 'Tumi. & Ollachea, & * & $"$ & $"$ & 173. \\
\hline 15. & Hoe (not finished) & $"$ & $"$ & $"$ & $"$ & 172. \\
\hline 16 & Axe, & Quiaca. & $"$ & ") & $"$ & 167. \\
\hline 17. & Topu, & Pelechuco, & $"$ & $"$ & $"$ & 317. \\
\hline 18. & Hoe, & Ollachea, & " & $"$ & $"$ & $I>I$. \\
\hline
\end{tabular}

(See also the list of objects analysed p. 163). 


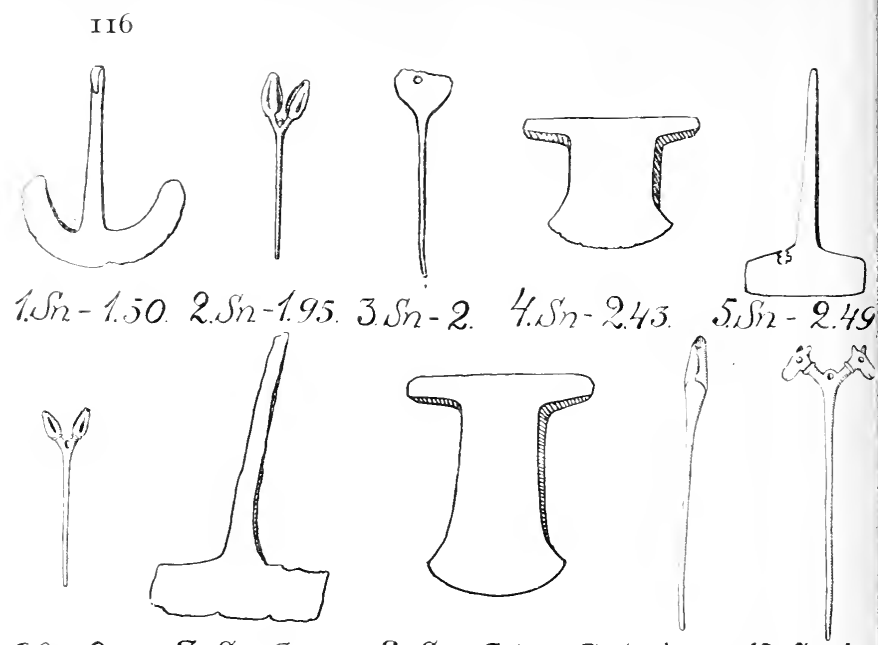

6.5n-2.67 7.S.5n-3.4 8.5in-3.29.9.5n-4.08 10.5in-4.4

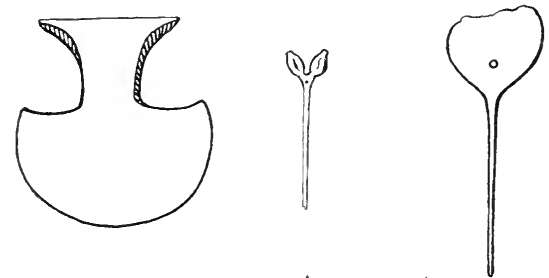

11.5n-4.67. 12.5n-4.91. 13.5n-5.
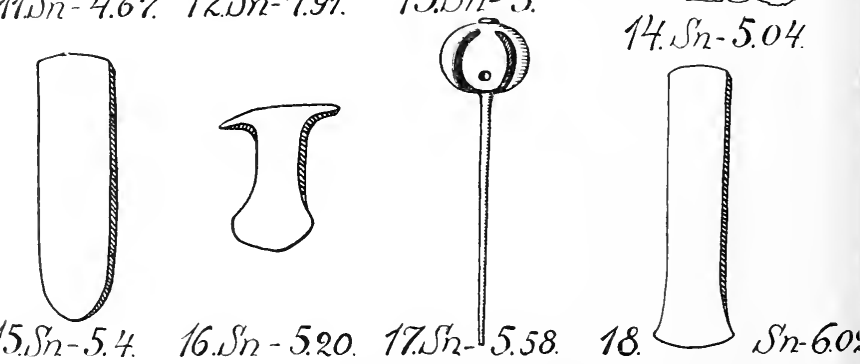

15.5n-5.4. 16.Sn $-5.20 .17 . S_{n-2} 5.58$

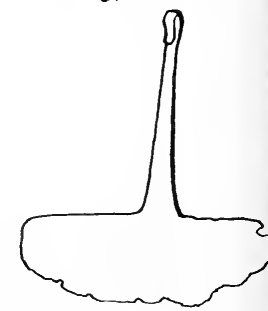

14. Sn -5.04<smiles>C1CCCC1</smiles>

(2) 

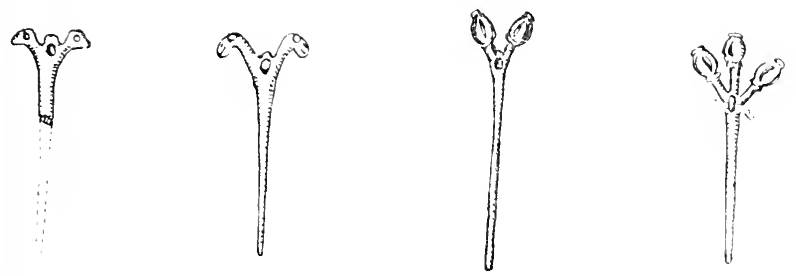

\section{1. $S_{n-6.21}$ \\ 2. $S_{n-7.71}$ \\ 3. $s_{2}-7.66$ \\ 4. Sin 7.87}
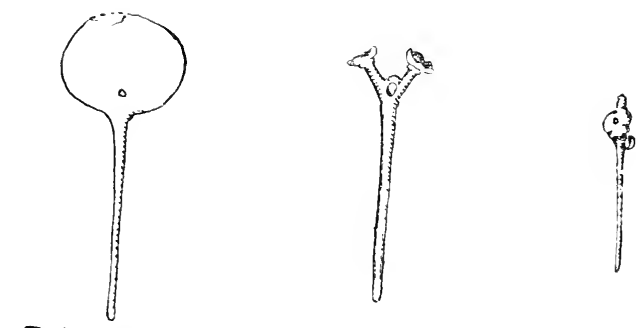

$5 . \sin -7.95$

\section{Sn-8.87 $7 . S_{n}-9.02$}

Figs. $f^{9,1}-f^{9}, 7$. 'Tumis of bronze from the boundary districts of Peru and Bolivia that have been analysed. (All collected by the anthor).
I. Queara,
R. M. Of. I. 349, (See p. 162).
2. Pelecliuco,
" 335 ,
3. Capamitas,
" $404,1 / 3$.
4. Queara,
"366, (Sce p. 162).
5.4
" $37 \mathrm{x}, 1 / 3$.
6. Capamitas, " " fo5, $1 / 3$.
$\%$.
361, (see p. 162). 
Professor G. Bodman has analysed for me various very fine Topus from Chulpas in the border country of Peru and Bolivia (figs. 48 and 49). They are ornamented with the heads of animals or with flower-buds, and some of them must have been hard to cast. It is scarcely possible to say whether the Topus that were hard to cast contain more tin than the simple ones. Ornaments from these parts certainly contain more tin than implements, but we do not know whether the former are from the same period as the latter. The ornaments were found in graves, the implements were occasional finds.

The Indians must have discovered, as soon as they became acquainted with bronze, that bronze is easier to cast than pure copper. The question whether they purposely mixed more tin in the bronze that was to be made into fine ornaments than in the bronze for simple objects, does not, however, seem to be satisfactorily answered by the statistics.

We nust remember that even in the Copper Age the Indians made ornaments and implements that were hard to cast. To an Americanist, therefore, such an argument as Gowland's is incomprehensible; he writes: "In this connection there is an important fact, well known to metallurgists, but sometimes overlooked by archaeologists, which cannot be disregarded, $i$. e., that copper objects can only be cast in simple forms in an open mould. In a closed mould such as was necessary for palstaves or socketed celts and the like, copper cannot be satisfactorily used, as when so cast the implement or object would generally be full of cavities and worthless for any practical purpose. Hence it is that only flat celts and knife or dagger blades of simple forms could be made of copper. $»^{1}$ )

The variation in the percentage of tin in the S. American bronzes may, in my opinion, be explained by the Indians having used different recipes at different periods for 
adding the tin, or, and especially, by the difficulty of apportioning the tin. If the tin or tin ore was not weighed before being added to the copper, but was added, so to speak, by feeling, a variation of a few percent in the quantity of tin could easily arise at different castings. It should be remembered that the variation of the proportion of tin in, for instance, a kilogramme of copper from $5 \%$ to $10 \%$, means that only from 50 to Ioo grammes of tin were added. As can be seen from the graphic representations on p. I 25 , the proportion of tin did not as a rule vary by more than a few percent. The copper objects that contained no tin are generally, as I have remarked, from the Copper Age, and those that contained a very small quantity of tin are generally from remote parts of the Inca Empire, where reconrse was perhaps chiefly had to old broken bronze that was melted down time after time, and lost some proportion of the tin at each recasting, always provided that this tiny proportion of tin (below $1 / 2 \%$ ) was not due to impurities in the copper ore nsed.

In the Old World, too, the tin in the bronze was not always very exactly apportioned in the Bronze Age. If, for instance, we regard the following table, given by MONTELIUS $\left.{ }^{1}\right)$ of analyses from the Farly Bronze Age of axes 'mit niedrigen Seitenränden und geschweifter bogenförmiger Schneide, gewöhnlich mit Andeutungen einer Rast', the variation in the proportion of tin in these axes is very similar to that in the S. American implements of the Inca period. Here is the percentage of tin as stated by MonTELIUS, to which I have added, for purpose of comparison, the percentage of tin in 'Tumis from Machu Picchu.

Axes (after Monteilus)

Sn- 2.80, 2.95, 2.96, 4., +.24, $452,5.68,5.8 \mathrm{I}, 6.28$, $6.36,7.40,7.81,8.22$, 8.55. $\%$.
Trumis (after Mathewson)

Sn- $0 ., 3 ., 3.67,4.22,4.82$, 5.1 $2,5.12,6.60,7.14$ $8.89,8.99 \cdot \%$

1) (I) Vol. 25, p. $4^{65}$, 
Gowland ${ }^{1}$ ) writes: "In fifty-seven analyses of flat axes the percentage of tin ranges from 3.0 to I3.I. In twentyfive examples only do the proportions range from 8 to II per cent. In six the tin exceeds II, and in twenty-six is less than 8 per cent."

He goes on to say: "In palstaves there is great diversity in the proportions of tin. In nine examples, two contain 9.2 and 10.9 per cent respectively, whilst in five the amounts range from 4.3 to $6 . \mathrm{I}$, and two have 18.3 percent each.

GOWLAND ${ }^{2}$ ) also records that near Segeberg in SlesvigHolstein a bronze axe was found containing $1.25 \%$ of tin along with two bronze armlets containing $5.83 \%$ and $6.35 \%$ respectively.

If we compared the analyses of all manner of copper and bronze objects from the Old World, from different times and different localities, we should certainly find that the tin had been mixed with the copper quite as much at random as the Indians are supposed to have done.

The possibility is not altogether precluded that the Indians sometimes added tin to the copper in order to give objects a more golden colour. BAESSLER ${ }^{3}$ ) mentions that in his collection he has several objects with this golden linstre. A bronze mirror(?) containing $90.64 \%$ of copper and $9.38 \%$ of tin, has stch a beautiful gold lustre that before making a close examination of it BAEssLER was under the impression that it was gilded. The fact is that on the Peruvian coast the Indians understood the art of gilding and silvering copper.

The Indians of Columbia made a speciality of altering the colour of metals ${ }^{4}$. They mixed copper and gold in all

1) P. 33.

2) P. 23 .

3) (I) 1'. 6.

-) See dF CRÉQUi-MONTFORT. RIVET aNd ABSANDAUX, p. 556 . 
possible proportions, and, as has recently been shown by Absandaux, Rivi:t and De Crégum-MontFort, conld redeem the copper from the surface of an object made of copper mixed with gold, by means of a vegetable acid, so that only gold remained.

We must however, also be on our guard against assuming, from the colour alone, that tin is present or not, as some investigators have done. Copper that contains much arsenic also has a gold lustre. Copper of this kind was in use anong the Indians on the Peruvian coast, and they seem to have used it chiefly for the points of hoes or spits. The liardness of an inplement of this sort (containing $\mathrm{Cu} 95.62 \%$, As $4.27 \%$, Sb $0,08 \%$ ) has been tested by Mr HutTGREN, and the result shows that the hardness, which had been increased by hammering, is not less than in the implements that are made of bronze containing about the sane amount of tin as these do arsenic. It is possible that the Indians who had access to this arseniferous copper were not particularly anxious to barter for bronze from the mountain region, their arseniferous copper being almost equally hard though more brittle. 


\section{CHAPTER VIII.}

\section{The Standardization of Bronze in Inca Times.}

I pointed out in the previous chapter that during the S. American Bronze Age tin was probably not always apportioned according to the same recipe.

In the graphic representations (Fig. 50-5t) we can see the variations in the percentage of tin in the bronzes that have been analysed from the Chulpas, the Peruvian coast, Tiahuanaco, Machu Picchu, Titicaca Island, and Argentina. 'This shows the variations in the percentage of it better than if they were expressed in maxima, minima, and averages. Even the averages may depend very largely on fortuitous circumstances when there are so few analyses under consideration.

It will be noted that the proportion of tin in the bronzes from Argentina varies much more than in the bronzes 
from Machu Picchu. In the latter the proportion of tin in most of the objects is between $3 \%$ and $6 \%$. Machu Picchu is Incarian, and all the objects found there are from Incan times, presnmably late Incan. T'he Bronzes from Argentina may be from very various times. They are also from a much wider tract.

If we compare the analyses from Machu Picchu with those from the Peruvian coast, we shall find that, with the exception of numerous objects of pure copper, the great majority of the bronzes from the latter tract also have a percentage of tin of $3 \%$ to $6 \%$. The explanation of this conformity may be that the bronzes from the Pernvian coast, like those from Machn Picchn, are for the most part presumably Incan. I have already pointed out that it probably was not until the conquest of the coastal regions by the Incas that bronze came into universal use there.

If we then compare the analyses from Machu Picchu with those from Tiahuanaco and the Chulpas, we shall find that the percentage of tin in the bronzes from the latter is somewhat higher than in those from Machu Picchu. Whether this is mere chance, due to the insufficiency of the material analysed, the future must decide. Of the bronzes from the Chulpas it may be said that on the whole they must have been harder to cast than those analysed from Machu Picchu. But the same cannot be said of the objects analysed from Tiahuanaco.

Occasional finds from the border districts of P'eru and Bolivia, which Professor Bodman has analysed for me, have on an average a lower percentage of tin than grave finds, i. e. the finds from the Chulpas. But, as we have remarked, it is nuknown to what extent the two kinds of finds are contemporaneous.

From the graphic representations showing the proportion of tin in the bronzes from 'Titicaca Island, I would conclude that the objects analysed are in part from Incan times, in part from the Chulpas, which is confirmed by 
124

BANDEIrER's investigations, of the archaeological remains on the Island. ${ }^{1}$ )

It appears from what I have said, that although the material analysed is insufficient and to a great extent unsatisfactorily collected, we can speak of a standardizing of the bronze in Incan times, or in late Incan times.

1) It is evidently, at least in part, the matcrial that BANDELII: collected on Titicaca Island that is used by MEAD for his analyses. 
Number of objects analy'sed

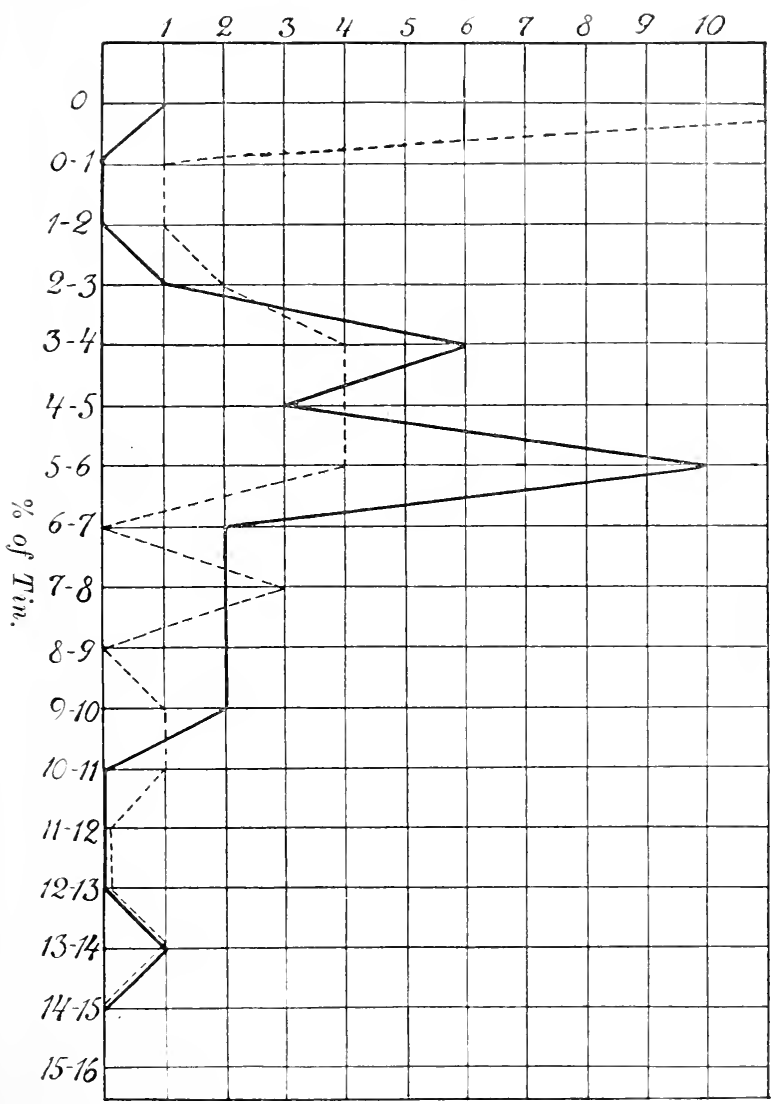

Fig. 5o. Comparison between the $\%$ of tin in the bronze articles from Machu Picchu and those from the coast of Peru. The black line shows the $\%$ of tin in the former, the dotted line in the latter. 


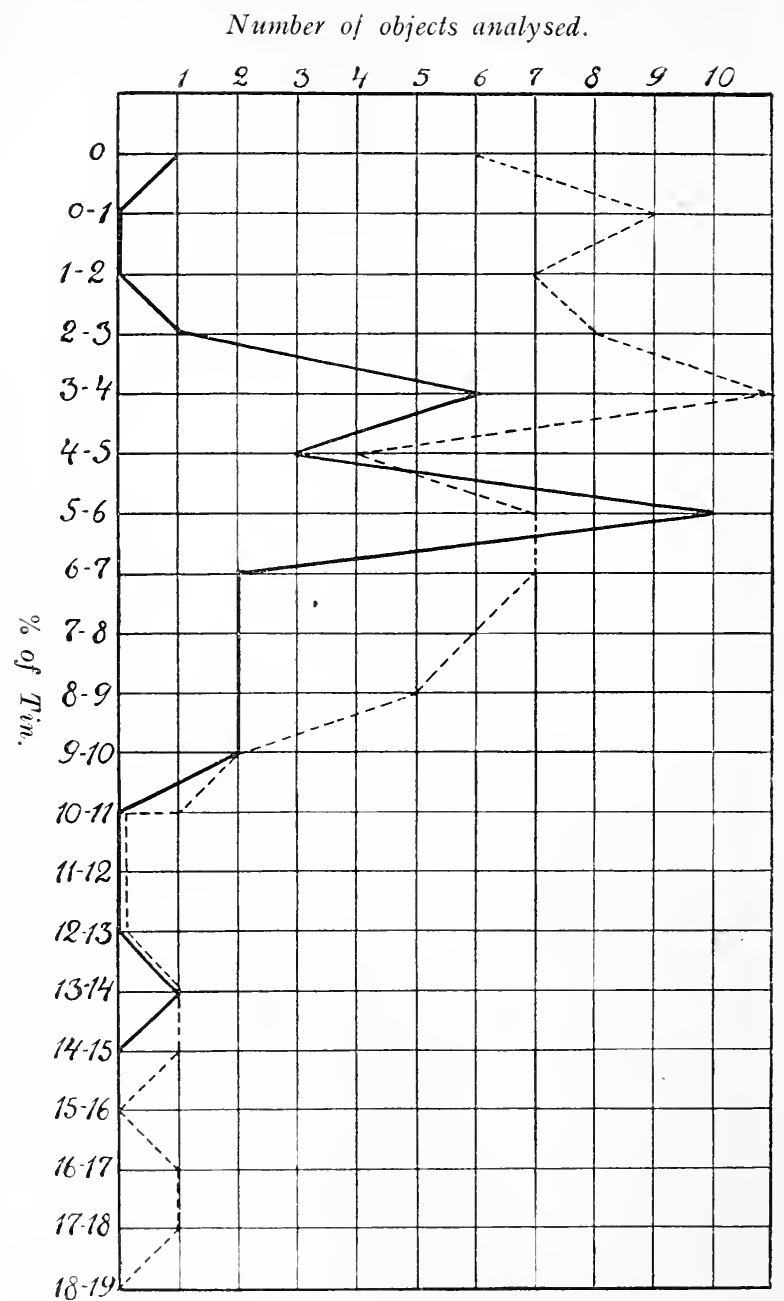

Fig. 5r. Comparison between the $\%$ of tin in the bronze articles from Machu Picchu and Argentina. The black line shows the $\%$ of tin in the former, the dotted line in the latter. Four objects from Argentina with $29 \mathrm{r} \%, 22.40 \%, 30.15 \%$ and $55.60 \%$ of tin, respectively, are not included. 


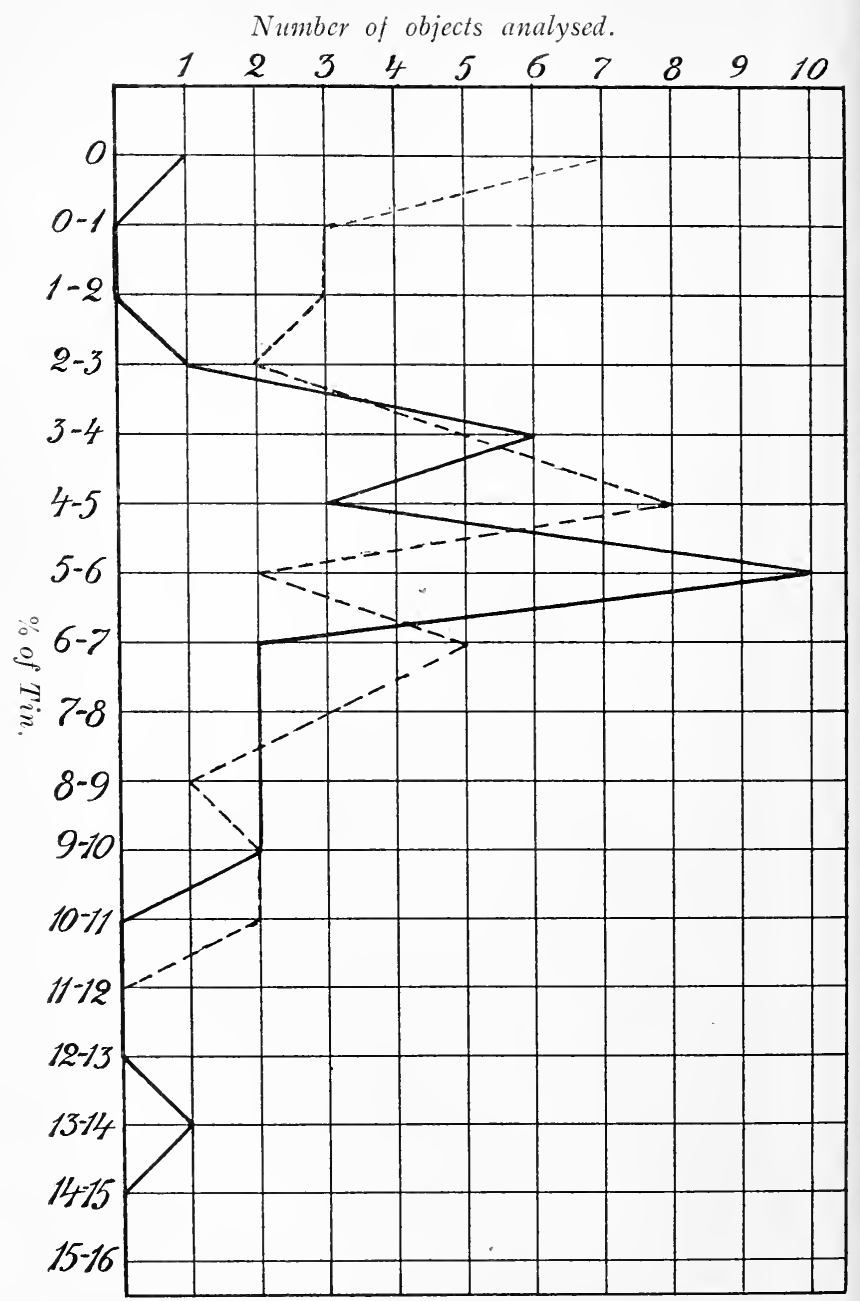

Fig. 53. Comparison between the $\%$ of tin in the bronze articles from Machu Picchu and those from the Island of Titicaca. The black line shows the $\%$ of tin in the former, the dotted in the latter. 


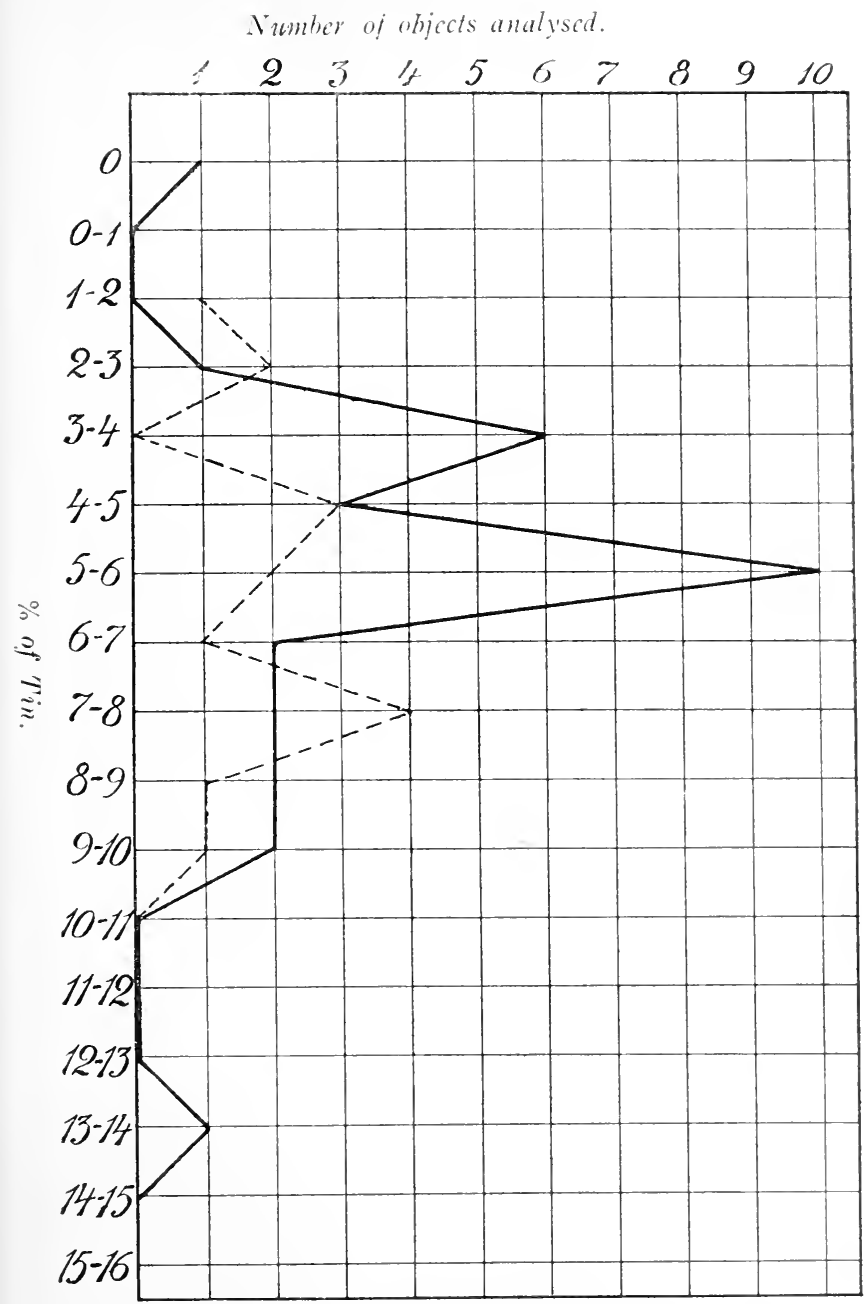

Fig. 54. Comparison between the $\%$ of tin in the bronze articles from Machu Picchu and those from the Chulpas. The black line shows the o of tin in the former, the dotted in the latter. 


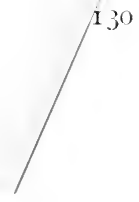

\section{CHAPTER IX.}

Where were the Copper and Tin Ores obtained, and where were the Copper and Bronze objects made:

I have already mentioned that, according to BARBA, a tin mine and a few copper mines were worked in pre-Columbian times. The tin mine was near $\mathrm{I}_{1}$. 'Titicaca, at Carabuco, but several other copper mines and probably other tin nines, too, were worked by the Indians.

As we know, Bolivia is now one of the chief tin producing countries, all the tin coming from cassiterite. At several places, i. e. in the auriferous sand at 'Tipuani, so-called stream-tin is found, and is separated from the alluvium by 
washing. ${ }^{1}$ ) As the cassiterite is heary, (specific gravity, 6.8 to 7 ), it renains in the buddle to the last with the gold. It is not unlikely that it was while washing for gold that Indians first observed cassiterite, which has no other qualities than its weight that could have aroused their interest. It is brittle, and has not a metallic appearance ${ }^{2}$ )

Cassiterite has not been found in Peru except at Moho near $I_{1}$. 'Titicaca, where it occurs as a rarity together with plumbostannite ${ }^{3}$. Nor has cassiterite been found in Ecuador.4) It may be objected that Peru and Ecuador are so little known that there may be undiscovered tin mines. This is possible, though scarcely in the parts that belong to the cultural regions of the Incas.

As far as we know, therefore, the Indians in Peru and Ecuador got the tin for their bronze from Bolivia. 'This presupposes that throughout these parts the Indians were

1) IORBES (2) p. $133 /$ mentions that native tin has been found at Tipuani. He devotes a detailed discussion to this, which he finds rery remarkable. He even throws out the supposition that the tin might be derivable from the pumps at the gold-washings, on which certain parts were of tin. But he rejects this theory because the metallic tin occurs in such quantities and in such large pieces. The largest piece Forbes found weighed 505 grs. He goes on to say: Mre we to suppose that some of the Cassiterite may have been reduced and melted by forests on fire, as before hinted as possible although not very probable? I record the facts lere, but must say I am puzzled to come to a definite conclusion; for the tin itself in no specimen yet observed was associated with a veritable rock matrix. True it is that it was always extremely impure, and contained stony matter thronghout its substance, as if entangled in it, as would be expected in case it had been thrown on to ground when in a fused state; yet its appearance left the distinct impression in the mind of its having been melted in an ordinary manner., Forbes, p. 135. (Researches on the Nineralogy of South America II.)

$\left.{ }^{2}\right)$ This presumes that the Indians invented bronze themselves, and did not originally get the invention from the old World.

3) See Ramoxdi, p. Io8. Exock, who studied the occurrences of minerals in the areater part of Peru, writes therefore on 1). 18 \& that he came across all sorts with the exception of tin.

4) JIJóx V CAAMÃ̃o (2), p. 23. 
in lively commercial intercourse with Bolivia. We have also concluded that it was not until the Incas had conquered the country that the Indians of the Peruvian coast and Ecuador presumably passed ovet in general from the Copper Age to the Bronze. It was thanks to the highly developed system of conmunications organized by the Incas that the Indians in a large part of western S. America were enabled to get in touch with the tin mines of Bolivia. To the north of the Incan Empire or the Continent, i. e. to what is now Columbia, the knowledge of bronze, as we have mentioned, never spread.

In Argentina much cassiterite has been found in Puna de Atacama ${ }^{1}$ ) and in La Rioja ${ }^{2}$ ), and the Indians there may very possibly have been independent of the Bolivian tin mines. This would explain why local forms, in contradistinction to those in Ecuador and the Peruvian coast, are generally of bronze and not of pure copper in Argentina.

The question is in what form the tin was sent out from the districts where there was tin ore. It may have been in the form of finished bronze implements, in the form of unwrought bronze metal, as tin ore, or as pure tin." Since copper existed in Peru and Ecuador, and only the tin was wanted, they possibly got it in mineral form, or even as pure tin.

At Machu Picchu Bingham found pieces of pure tin, which seems to prove that in Incan times the Indians there knew this metal and were not forced to obtain bronze by alloying tin ore and copper ore. MATHEWSON ${ }^{3}$ ) also points out that most of the bronzes found at Nachu Picchu are of such fine quality, a mixture so free from impurities, that the metals were probably not mixed until they had been melted down from the ores.

But the possibility always exists that the tin Bingham

\footnotetext{
1) WAITHER PFACK, p. 23.

2) AMBROSETTI (I) P. ISZ.

3) P. 5.37 .
} 
found at Machu Picchu is post-Colmmbian. Against the theory that pure tin was known in pre-Columbian times we have the circumstance that, in spite of the quantities of archaeological finds made 'within the old cultural area, of the western part of South-America. there is not a single find of pure tin from any other place than Machu Picchu. ${ }^{1}$ ) If pure tin, and not tin ore, had been in general use for nixing with copper to make bronze, there should be some occasional find of an article made of tin. There never has been. Nor has tim been found employed for soldering; when two copper-pieces were to be joined together, the method employed was w'elding. (See Appendix B.) In post-Columbian times, on the other hand, pure tin came into very general use among the Indians.

Very likely it was not until late Incan times - and Machn Picchu is presumably late Incan - that the Indians got so far that they could make pure tin. This wonld explain the standardization of the percentage of tin that can be noticed at Machu Picchu, for it must have been easier to obtain the desired percentage of tin in the bronze by mixing tin and copper than by mixing tin ore and copper ore. If it was only a short time before the Conquest that the Indians became acquainted with pure tin, this would explain why no tin articles have been found among the innumerable objects discovered, for instance, on the Peruvian coast. ${ }^{2}$ )

To judge from what we know about Indian barter, it is probable that bronze was also circulated in the form of finished articles. This was perhaps the commonest way. But it would of course not prevent these articles from being afterwards melted down and recast in new forms.

It is also possible that very stanniferons bronze, which

1) I do not include the doultful find of pure tin at Tipuani.

$\left.{ }^{2}\right)$ A few objects of lead, on the other hand, have been found there and described (BAEssLER, (I) P. I69). It is doubtful whether they are preColumbian or not. 
was afterwards mixed with pure copper, was obtained from the districts where there was tin. BERTONIO, as I mentioned before, speaks of a kind of copper which the Indians used as we use steel, and which became stronger by being mixed with other copper. He seems to be referring to very stanniferous bronze which was capable of use when mixed with other copper. Very stanniferous bronze of this kind is really found in Argentina. Two bronze implements have been found there containing as much as 30 and $55 \%$ of tin. These were of course quite unserviceable as implements, but they show us perhaps in what form, at least sometimes, the bronze circulated about from Bolivia to distant tracts.

In the rich collections of the Ethnographical Museum of Berlin I tried to find objects that I imagined could be of such a bronze. I succeeded in finding a small axe-shaped object (Fig. 2 E) from Omasuyu in Bolivia that seemed to be of such a bronze with a large \% of tin. This axe has no edge and can never have been used as an implement. When analysed it contained $17.78 \%$ of tin, It has a hole in the middle, probably for suspending.

In Argentina bronze was certainly melted in crucibles, as these have been found there: The metal remaining in one of them has been analysed and found to have the same composition as the commonest bronzes. ${ }^{1}$ ) Several castingmoulds have also been found in Argentina. One has also been found in Ecuador ${ }^{2}$ ), and is for a type of axe that is generally of bronze. From Argentina AmbroSETTI $^{3}$ ) describes and depicts a casting-mould of terra-cotta for a 'T-shaped axe. A mould of porous earth, in which were presumblay cast little round disks, was found by DEBENEDETTI ${ }^{4}$ ) at Barrealito in San Juan. He also speaks of finds of other moulds in Argentina. A form of metamorphosed slate ('pizarra metamorfa') in which some curious or-

1) Sn, 4.854. Cu, 95.055. I'e, o.o9o. Loss, o.oor. DebeNenderti(2) p. I I 6.

2) BU:MWALD.

3) Ambrosfitt, El Bronce, Irig. 6 .

1) (2) P. II 7 . 
nament was cast, is depicted by PosNanskY ${ }^{-1}$ ) from Tiahuanaco. It is very doubtful whether this is pre-Columbian. But the fact remains clear that all the way from Ecuador to San Juan in Argentina the art of casting was understood. It is impossible that the art should have been unknown in the central parts of the Inca Empire when it was known on the outskirts. The Columbian Indians, as we know, were very clever at casting by the method called 'a cire perdue'.

Whereas tin is only found in part of the old territory of the Inca Empire, copper is found alnost everywhere, and the trade in copper is scarcely likely to have been very extensive, though, for all we know, it may have been.

In all probability the Indians used native copper to a large extent, it being found at Corocoro in Bolivia and at many places in $\mathrm{Peru}^{2}$ ) Boman assumes that besides native copper the Indians used copper silicate (Chrysocolla) and presumably also copper carbonate (Malachite and Azurite) and cuprous oxychloride (Atacamite). He considers the copper used for the Tiahuanaco cramps previously spoken of, to be 'd'un'sulfure de cuivre'.

Boman has already called attention to the importance of studying the impurities in copper and bronze objects in order to discover what kind of copper mineral the Indians used in different localities. Jijón Y CAAmaño has gone further. He has published, as we have said, a large number of analyses of copper and bronze objects from Ecuador. The analyses have been carried out by MEsTANZA. For each analysis the latter has used about one gramme. Eight of the objects analysed contained tin. All the objects analysed contained a little lead, varying from o.OI \% to I.I4 $\%$, as well as iron, varying from $0.03 \%$ to $0.55 \%$. A11 but one contained traces of arsenic, $1_{3}$ traces of zinc, and 9 traces of silver. Jijón y CAamaso points out that the same

1) (2) fig. $38 \mathrm{~g}$.

2) RAMONDI, p. 84 . 
impurities recur in the pure copper objects as in most of the bronzes, and from this draws the conclusion that if the copper in the pure copper objects is from Ecuador, the copper in these bronzes is from the same locality. On the other hand, he thinks the tin was imported, as tin ore has never been found in Ecuador. Basing his opinion on the find in Machu Picchu, he holds that the tin was imported in the form of pure tin.

Jijón y CAAMAÑo has furtherniore made a list of all the known analyses of copper and bronze objects from $\mathrm{S}$. America with the same impurities. He places together, for instance, all the analyses that, besides $\mathrm{Cu}+\mathrm{Sn}$, yielded $\mathrm{Fe}+\mathrm{Pb}$, or $\mathrm{Fe}+\mathrm{Pb}+\mathrm{Sb}$, etc., and in this way he obtains 39 varieties. But the question remains whether the material of known analyses is serviceable in its entirety for such an investigation, which JIJÓN Y CAAMAÑ $O$ himself seems to be doubtful about. If we go through all the known analyses, we shall find that WISSLER, for instance, in his analyses, published by $\mathrm{MEAD},-$ and these are the greatest number that have been published - has not always fully investigated the impurities. The problem that MEAD had set out to solve was to decide whether the tin had been intentionally or unintentionally mixed with the copper. Very small quantities of metal were used for the analyses. WISSLER, who made the analyses, says: "Owing to the small amount of drillings taken for the analyses, in some cases only o. o7 gram. the results should be taken as a close approximation of the true composition". If we look at the tables of analyses in DE CREqui-MontForT and Rivers's work, we shall find that 25 objects from 'Tiahuanaco were analysed, 7 of which were published by Boman. In all these iron has been found. In the remaining IS objects, according to the analyses, iron occurs in only one. The analysis of this object was published by UHLE. The I7 objects examined by WISSLER were presumbly not tested for iron. In the same way Bomas fornd lead in most (6) of the objects he examined Wiss- 
I.ER found lead in one object only, in another the occurrence of lead is stated as (?), in five lead is said to be absent, and no detail is given about the remainder. Boman found sulphur in both the cramps from 'Tiahuanaco that he examined. In the 5 cramps that Wissider examined, he only found traces of sulphur in one.

There is cause to doubt whether the other analyses from 'Tiahuanaco were as detailed as Bonis's, and whether several other objects from there would not prove to contain lead, and even iron.

If we compare the analyses from N. Argentina published by Boman, with most of the others from there, the former strike us as far more complete. When two chemists analyse the same object, they may arrive at very different results. Ambrosetri ${ }^{1}$ ) got two chemists to analyse two axes. One found iron in both, but no lead. The other found traces of lead, but no iron. In one axe one of the chemists found r. $\%$ of nickel. The other chemist does not mention nickel. The analyses claim to be complete.

This does not stand in the way of JIJón Y CAAMAÑo being engaged in a right method, which has been used with advantage in the Old World. One should only make use of such analyses as are complete. Among these we may count, besides Boman's, those especially of BAEsSLER, MATHEWSON, and the analyses published by JiJón Y CAAmaño himself. ${ }^{1}$ )

From the material of complete analyses as we now know it, the fact remains that certain combinations of impurities are characteristic of certain districts, caused by a certain kind of copper ore having been used. Antimony may also come, as Bound has pointed out, from impurities

1) In the present work only some of the analyses are complete. The reason of this is in part that if a complete analysis is to be exact the chemist requires about I gramme of material, and so much cannot often be sacrificed without considerably damaging the object analysed. Again, it is very expensive to have a large number of analyses carried out. It must have hurt Dr. Jijóx y CAAmaño to take a gramme of metal from each of the beautiful 'tincullpas' examined by him. 
in the tin. The virgin tin from Machu Picchu contains a little antimony $(0.08 \%$ ).

Traces of arsenic have been found in all save one of the copper and bronze objects from Ecuador that have been analysed by MESTANZA. Considerable quantities of arsenic - I.55, 2.I $4,4.03,4.27$ and $+.43 \%$. - have been found in five objects from the Peruvian coast. Only one object from the mountains of Peru and Bolivia has proved to contain arsenic. In Argentina traces of arsenic have been found in two bronze disks and a copper cramp, while a copper disk proved on analysis to contain not less than $5.20 \%$ of arsenic. This is one of the few objects from Argentina that are free from tin. The analysis is published by BomaN ${ }^{-1}$. One may well wondre whether the object in question, or the metal for it, was not imported into Argentina from the Peruvian coast.

Sulphur occurs in small quantities in many of the bronzes from Machu Picchu, but is rare in S. American copper objects from other places. Boman, as I mentioned, has recorded that it is present in the two cramps from Tiahuanaco that he had analysed.

Lead is an ingredient in all the objects from Ecuador that Jijón Y CAamano has analysed. It seems to be rare, on the other hand, in things found on the Peruvian coast. In copper objects from the mountains of Peru it still seems to be rare, is somewhat commoner in Bolivia, and general in Argentina.

Antimony occurs above all in bronze objects from the tracts round L. Titicaca. In the objects from Ecuador no antimony has been found in what has been analysed. From the coast of Peru MEAD mentions traces of antimony in a knife, and Dr Almström found $0.7^{\circ}{ }_{0}$ of antimony in a copper hoe that he analysed for me, while in another he found $0,08 \%$. Antimony is not mentioned from Machu Picchu and Cuzco. I' 1 N. Argentina traces of antimony have been found in three objects, in E. Bolivia in one and at Paraná-Guazí in another one.

i) (I). 
Nickel is rare. It has been found in four objects from licuador, and in five from Argentina. Bismutl oceurs in a few objects from Argentina with a conpllicated but curiously similar composition

$\mathrm{Cu}$ Sil Fe $\operatorname{Ag} \mathrm{I}^{\prime b} / \mathrm{n} \quad \mathrm{Bi}$

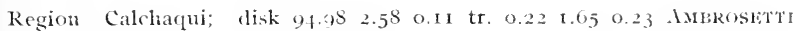
2 , p. 304

I.uracatas (Mol. Salta) $94.953 .030 .37-0.210 .940 .33$,

Bismuth has been found in only three other objects, two found by me in the Queara valley in N. Bolivia near the Peruvian border and one in E. Bolivia.

Very similar is the conmosition of the 'laminas de cobre' found by 'ToRres in a mound at Paraná ('uazú. It is also highly probable that these, which must have reached Rio Parana from the mountains by trade intercourse, derive from the same place.

$\mathrm{Cu} \quad \mathrm{sin} \quad \mathrm{Pb} \quad \mathrm{Zn}$ Fie Sb'lorres, 1.5 ; Lamina I $95.880 \mathrm{I} .4 \mathrm{I}+0.7520 .282$ tr. tr. "

$\begin{array}{llllllll}" & 2 & 91.425 & 0.609 & 0.366 & 0.488 & \text { tr. - } & \text { " } \\ " & 3 & 86.088 & 3.282 & 0.746 & 0.300 & \text { tr. - } & \text { " } \\ \prime & 4 & 91.890 & 0.768 & 0.171 & 0.340 & \text { tr. - }\end{array}$

We are reminded of the Calchaqui district, where zine occurs, in addition to the above-nentioned disks, in two other objects, a disk and a 'fragment de plaque'. Apart from undoubtedly post-Columbian things, zinc has only been proved to occur in two objects from Machu Picchu, one from E. Bolivia and in a few from Eicuador. JIJón Y CAAmaÑO ${ }^{1}$ ) also compares the composition of the objects from Paraná-Guazú with the composition of the disks from the Calchaqui district, and writes: "Estas composiciones parecen bastante locilizadas en la porción andina de la Republica Argentina, de donde obtenían quizats, sus objetos metálicos, los aborígines del Paraná-Guazú."

1) (2) 1'. 24. 


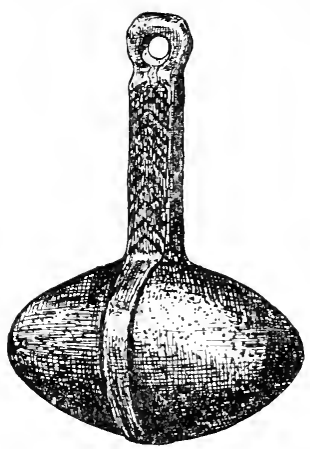

Fig. 55. Bolas of copper from Iiscoma on I. Titicaca. R. II. $05.17 \cdot 192,{ }^{2}{ }^{2}$

\section{CHAPTER X.}

The Origins of the $S$. American Copper and Bronze Ages in the S. American Stone Age.

In the previous chapters I have attempted to study the S. American copper objects in order to find out, as far as possible, the relative chronology of the different forms, and to unravel, from various points of view, the problem of the development of the Bronze Age from the Copper Age. I will now pass on to an attempt at collecting such facts as seem to show that the S. American Copper and Bronze Ages have their roots in the $\mathrm{S}$. American Stone Age. An investigation of this kind must precede a discussion concerning the delicate question as to whether there is any connection whatsoever between the Copper and Bronze Ages in the Old World and in the New.

It is of great interest to find objects of stone, wood, bone, or fruits corresponding to the copper objects found in S. America. 
The ' $\mathrm{l}$-shaped axe, as we know, is also found in stone, and in this form the stone axe has had a greater distribution than the copper and bronze ones. This distribution has been studied with the greatest exactitude by RIVET and VER$\mathrm{NEAU}^{1}$ ). They sum up the result of their investigation as follows: "A notre avis, les trois variétés de haches à oreilles que nous venons de décrire sont toutes derivées les unes des autres par suite d'une évolution progressive, marquée par l'amélioration constante des procédés de fixation de l'outil au manche... La hache à oreilles semble être un type essentiellement sud-américain, dont l'origine doit être cherchée, croyons nous, chez les peuplades de l'est et din nord-est de ce continent, son introduction sur les hauts plateaux n'étant que secondaire. Dans cette région, aux mains de populations plus civilisées, l'outil évolua rapidement vers des formes plus pratiques et plus maniables, et nous verrons que c'est là enfin l'instrument de pierre fut remplacé par l'instrument de cuivre."

As we see from this quotation RIVET and VERNEAU are sure that the ' $\mathrm{T}$-shaped metal axe is a copy of the ' $\mathrm{T}$-shaped stone axe. Because of the extensive distribution of the ' $\mathrm{T}$ shaped stone axe, I am inclined to think the famous French archaeologists are right. An argument in favour of the $T$ shaped stone axe being more original than the $\mathrm{T}$-shaped metal axe is the circumstance that in the border districts of Peru and Bolivia I did not come across a single axe of any other type than this save its closely' related 'hache a encoche'.') Quantities of these axes (see Map, 2) are to be fonnd there. In other parts of Bolivia that I visited they are only to be found sporadically, the prevailing types of axes being quite different. If in N. E. Bolivia and the bordering districts of Peru they had not become acquainted with this type of axe until they had established communications with the cultured metal region in the west, we should in these parts find

1) (I) P. I 5.5 .

2) The distribution is studied by Rrire and Virsade A copper axe of this shape is depicted in Fig. 2 F. 
MaP. 2. Map showing the most important types of stone axes found by me during my travels in E. Bolivia and surrounding territories. In addition to my finds are included some axes found by vox ROSEN in the Tarija Valley. liron the schematic drawings we can see not only the types of the axes fonnd, but also their approximate number. The all black figures indicate that these types of axes were in use recently, or still are in use, in that district; the size of the drawings has no signification in there cases.

In the explanatory figures, the T-shaped axe with semicircular edge has not been included, as it only occurs in two examples. Minor variations in the shapes of the axes are not indicated in the map; only the main types are shown.

The route of my last journey in $s$. Anerica (I9I3-I9I4) is alone marked on the map.

All the axes depicted on the map are kept either at the Gothenburg Museum or at the Riksnumseum in Stockholm 
some type of stone axe that was in earlier use. The distribution of this type of axe in the territory I examined also speaks in favour of RIVET and VERNEAC's assumption that the people of the Andes got it from the east.

On the other hand there is something to be said for the theory that the T-shaped metal axes are more original than the 'T-shaped stone ones. It is possible to imagine, I take it, that the Indians who had no access to copper, or not enough copper, should have copied the metal axes in stone, and that these types of stone axes based on metal ones should have been passed on to places far away where it was impossible to get copper. These types of stone axes may afterwards have been modified somewhat to make them less fragile. The T-shaped axe that is to be used for practical purposes has actually a shape that is much more natural in metal than in brittle stone. In Egypt, as I shall point out shortly, this form of axe occurs both in stone and metal. Flinders Petrie considers the Egyptian stone axes of the $T$-shape to be copies of the metal axes of that shape.

The T-shaped stone axe is still in use, or at least was in use a few years ago among the little tribes east of Cuzco. The axe here depicted (Fig. 56 a) from one of these tribes, the Huaichipairi, is hafted in the same way as a T-shaped copper axe from Peru that is preserved in Madrid. (Fig. 56 b).

Stone axes with a little hole in them, like those of metal (Fig. 5d) have been found pretty generally, especially in Ecuador. Their distribution has been very carefully studied by RIVET and VERNEA( $\left.{ }^{-1}\right)$. I never came actoss them in my travels.

The star-shaped club-head of copper was, as we know, a commonly used weapon in Inca times, and numbers of these club-heads have been found in various parts of the old 


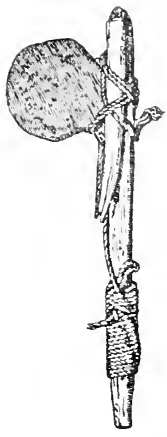

a

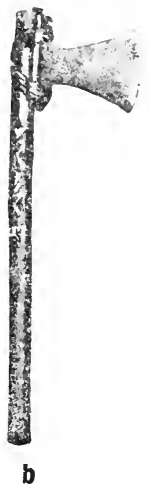

Figs. 56 a $-56 \quad \mathrm{c}$.

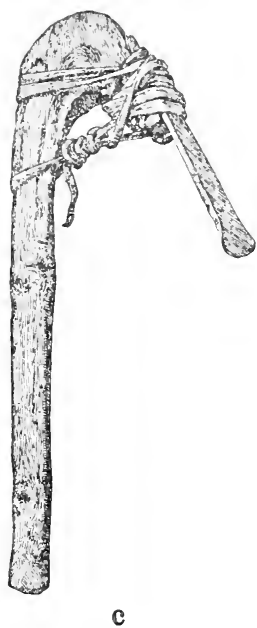

a- Hafted T-shaped stone axe from the Inaichipairi Indians in Peru. Modern. (R. M. 05. I6. fo6) I's.

b- Hafted T-shaped axe of copper from Peru. (After Bomix (I), fiy. I 5 b.) 1 :

c- Hoe with plate of iron. From the Quichua Indians. Modern. /R. II. 05. I6. 274). $1 / \mathrm{i}$.

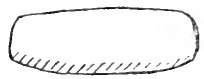

b

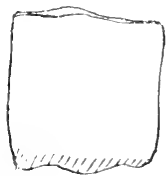

c

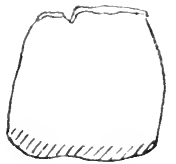

d

Iigs. 57 a -57 d. Square knives $1 / 1$.

a- of stone, Coast of Peru, After BAEssickr (I), fig. 7 fa. $^{2}$

b- copper, Chuquitanta, " " " 75 .

c一 wood, Choroti (Modern), G. M. 13. I. I13.

d-" iron, " "I3. I. IIf. 
territory of the Incan Empire. ${ }^{I}$ ) Exactly similar ones of stone have been pretty commonly found in the same districts. ${ }^{2}$ ) Round stone rings have a very wide distribution in S. America, and were presumably used there for various purposes. ${ }^{3}$ ) Thus, the Aymara Indians still use them as net sinkers. At Ica in Peru have been found clubs with heads of similar stone rings. In the Museum für Völkerkunde in Berlin there is a simple copper ring from Carabuco in Bolivia (V. A. 12407) which was probably used, like the stone rings, as a club-head.

As far as we can judge, the star-shaped club-head of stone is a specialized form of the simple stone ring, just as the star-shaped club-head of copper is a specialized form of the simple copper ring. But the development need not necessarily have proceeded in such a way that they first had the simple stone ring and then invented the star-shaped club-head of stone in its various forms. We may well imagine that they first had the simple stone ring, then copied it in metal, and then varied the forms of these club-heads in the more easily worked metal in different ways, inventing, among other things, the star-shaped club-head. This in its turn was again copied in stone. We must take into consideration a development of that sequence. The stone weapons certainly did not disappear with the introduction of metals, metal and stone being used by turns right into Incan times. In all probability the clubs from Ica with big stone rings were therefore from a time when metals were known, most likely from Incan times. They are extremely well preserved.

Square copper knives have been found in Argentina ${ }^{4}$ ), in the coastal regions of $\mathrm{Peru}^{5}$ ), in the border districts of Peru
1) Rivet and Verneau P. 279.
2) " " $"$ P. 172 .
3) " " P. 166.
4) AmbrosetTi, Eil Bronce, p. I 93.
5) BAESSLER (I), fig. 75 . 


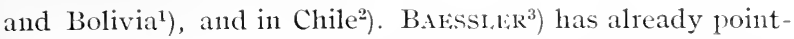
ed out that stone knives of this type are also found on the Peruvian Coast. (I ig. 57 a). In ny excavations at Caipipendi in S. Bolivia I also found stone knives of this kind. The Indians at Caipipendi had some pure copper, but commonly used stone axes. It is doubtful whether the stone or metal variety of square knife was the original one. The Indians in the Chaco commonly had the same type of knife made of hard wood (Fig. 57 c). I have seen it copied there in old broken iron (Fig. $57 \mathrm{~d}$ ).

The little club or bolas from Escoma on I. 'Titicaca, depicted in Fig. 55, is evidently a copper imitation of a fastened bolas stone; even the plaiting on the thong of raw-hide that probably held the stone, is indicated on the copper object.

We can imagine the copper spear-head to have been an imitation of the bone ones. Similar heads, still in use, e. g. among the Carajá, are so hafted that, as in the copper spearheads, the shaft is stuck into the head.

A great number of copper bells have been found in $S$. America, as well as in Central America and Mexico. Rivet and VERNEAU ${ }^{4}$ ) have given a careful account of their distribution. In the main we can distinguish two types, one with a little loop (Fig. $5^{8} \mathrm{c}$ ) and another (Fig. $5^{\mathrm{S}}$ b) with small holes for passing string through for hanging purposes. The latter type seems to me to be typologically younger than the former, this type of bell being very likely an imitation of certain palm-nuts. The resemblance between a palmnut and the copper bell here reproduced after SAVILLE, is striking. Palm-nuts are used, for instance by the Pauserna Indians, as dangles on the belt (Fig. $5^{8}$ a). The suspension holes in the palm-nuts are natural. Similar bells have also

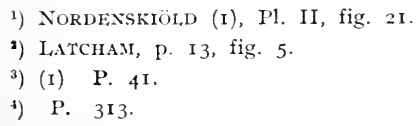




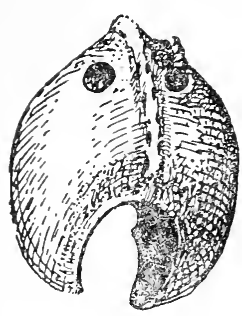

a

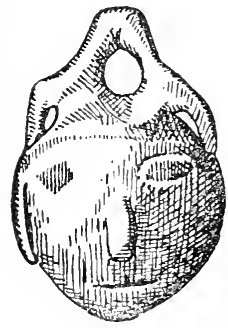

d

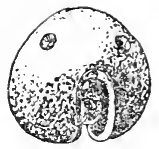

b

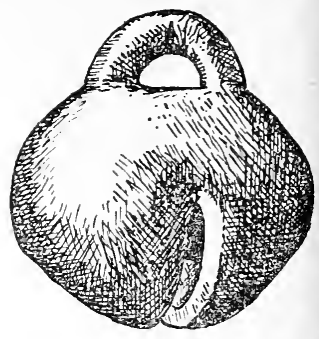

c

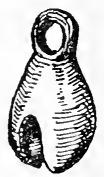

f

Iigs. $58 \mathrm{a}-58 \mathrm{f}$. Bells or rattles of palmnut or metal.

a- Palm-nut, Pendant to belt from the Pauserna Indians, Rio Guaporé. G. M. I5. I. 868 .

b- Bell of copper, Ecuador,

c- $\forall$ Lima,

After SAVILLE, T. II, P1. LXVI, fig. I 2. (Diam. I. $3 \mathrm{~cm}$.)

d- " "Chuquitanta,

$\mathrm{e}$ - " bronze, Chiriqui

"BAESSler (I), fig. 5 I6. 1/1.

f-" "bronze, "

$\Rightarrow \quad(1), \Rightarrow 5$ I $3 \cdot \% 1$.

Holmes, (I), 42 .

1) $4 \mathrm{I}$. 
been made of walnuts. One is described by LiRIC VON ROSIN ${ }^{1}$ ) from Casabindo in Puna de Jujuy. Similar ones were also found by Ambrose'tri²) in I a Paya.

UHLE $^{3}$ ) opines that shells were the first tweezers used for pulling out hairs, and that these were afterwards copied in metal. Shell-shaped tweezers have been found on the Peruvian coast. ${ }^{4}$ ) If UHLE is right, these should therefore be the oldest metal tweezers, typologically. The more triangle-shaped tweezers (Fig. 32d) should be typologically younger than the more shell-shaped ones. 'This is confirmed by the discovery of similar triangle-shaped ones at Machu Picchu, a type which, as I have pointed out, is generally, even when found on the Peruvian coast, of bronze and not of pure copper, like the nore shell-shaped ones.

Copper needles in S. America are presumably an imitation of wooden or bone needles. UHLE ${ }^{5}$ ) found a wooden needle at Arica. It is from the primitive fisher-folk which, according to UHLE, lived there before the Tiahuanaco culture, and were not acquainted with metal. Copper needles are found from Ecuador to N. Argentina, i. e. throughout the territory of the Inca Empire at its greatest expansion. ${ }^{f}$ ) Yet it appears from EATON's excavations at Machu Picchu that needles of plantspines were still in use in Inca times. A bronze needle from Machu Picchu is depicted by Mathewson. It is evident that in Inca times both metal needles and those of plantspines were used. GarciIASSO'S statement that no metal needles, but only those of spines, were in use in the Inca Empire, must be due to a

1) P. 153, Fig. 14t. See also p. $20 t$.

2) (3) In grave 72 .

3) (Pachacamac) p. 36 .

4) BAESSLER, (I) Figs. 274 and 238 .

5) (6) P. 8. As CHLE calls it 'aguja' and compares it with needles that I have described from El Gran Chaco, I assume that it has an eye, but it is impossible to see it from the unfortunately indistinct picture in his work.

${ }^{6}$ RIVET and Verneau p. 28,3 . 
mistake. He has probably only seen the latter kind, which must have been commoner than the former.

Fish-hooks have been found in several places in western S. America. They are of wood and bone (Polynesian form) or of some kind of spine, or of copper. The spine and copper ones have about the same form, the latter being apparently copied from the former, which were found by UHLE ${ }^{1}$ ) in very old graves of the primitive fisher-folk of Arica. Characteristic of all these S. American fish-hooks is that they are without barb. ${ }^{2}$ )

The copper knuckle-duster has been found in Argentina and Chile, and possibly on the Peruvian coast. Wooden ones are also known from $\mathrm{N}$. Argentina, from where v. Ro$\mathrm{SEN}^{3}$ ) reproduces one which, as he points out, must be an imitation of a copper knuckle-duster. Knuckle-dusters of wood, tapir skin and other material are still in use in the Chaco among the Choroti and other tribes. Wooden bells resembling the well-known copper bells (Fig. $27 \mathrm{f}$ ) from Argentina have been found in Puna de Jujuy and in Atacama $\left.{ }^{4}\right)$.

Also such things as pan-pipes, ordinary flutes, spindle wheels, and various ornaments have been found in Peru both of metal and simpler material.

Thus we see that to many copper objects there are corresponding forms of stone, wood, fruit-pods, sheils or bone: - The T-shaped axe, the axe with a little hole, the ring-shaped club-head, the star-shaped club-head, square knives, the bolas, little and big bells, the spear-head, the needle, the fish-hook, the knuckle-duster, and possibly tweezers etc.

It goes without saying that in a number of these the

1) (6).

2) Reiss and StÜbEL, I'l. 82, I'ig. 32-34 (Ancón), Medina, Fig. I23 (Copiapó).

3) Fig. 216. Morohnasi.

4) VON ROSFix p. I93. 
simpler material must have been the original material, in others, as I have mentioned, we may be in doubt. In many cases the sonrce of supply lias made the decision between the employment of metal and the simpler material, and this right up to the time of the Conquest.

We have seen from the foregoing that from these forms of metal implements and weapons, which seem to have their roots in the S. American Stone Age, we can typologically derive a nnimber of forms, inter alia the socketed axes, which were evidently therefore not invented in America until the Age of Metals. We have likewise followed the development on American soil of the 'Tnmi-knives. It is clear, too, that during the Copper and Bronze Ages the Indians in America invented a number of forms of weapons and implements, and also of course ornaments.

The metal implements which are most isolated, typologically, are the one-edged knives of the type depicted in Fig. $60 \mathrm{c}$. There is nothing to correspond to these in other material. Perhaps when we have more finds to work upon, we shall be able to derive these one-edged knives typologically from the square copper and stone knives. In the case of most ornaments it is now impossible to prove their origin from forms of simpler material. If we had access to a larger quantity of comparative material, however, this wonld presumably be possible in many cases.

When the Whites conquered the Inca Empire, they introduced finished implements of iron, which the Indians obtained by barter or in exchange for work. The Campas in Peru are, as far as I know, the only Indians who learnt from the Whites how to melt iron ore and make implements of it. Occasionally the Indians have themselves manufactured iron implements ont of old broken iron, and then it is easy to see how they cling to the old forms. In certain parts, when they obtained iron implements from the Whites, they preferred such as were made after their old fashion. 
I have already mentioned that the Indians of the Chaco make square knives like their wooden ones out of old iron. Adjoining is a picture of a modern hoe with a modern blade shaped and hafted like the copper ones that were used in pre-Spanish times (Fig. $56 \mathrm{c}$ ). Occasionally the Indians would alter an implement they had obtained from the Whites to suit their own taste. The Yuracáre break off and grind down a transverse edge on the ordinary knives they get from the Whites. 'They then put handles on them in a curious way. When they go into the woods or fields they carry them on their backs by a chord in the same way as, for instance, the Huanyam carry their knives or chisels of incisor teeth.

This all proves how the Indians cling to the old forms even when they have got to know a new material to make them of.

When in western S. America the Indians passed from the Stone Age to the Copper and Bronze Ages they evidently clung to the old forms in the same way. That the forms of their implements and weapons of pure copper and bronze are to a great extent presumably the same as were in use in the Stone Age, does not however prove that they invented the use of copper and bronze. The idea of using copper and of mixing copper with tin may have been imported, for thanks to their conservatism they clung to the forms they were used to in the Stone Age, and developed them further.

Still, it is evident in that case, that the beginning of the Metal Age in W. Sonth America does not stand in connection with these districts having been occupied by fresh settlers with new types of implements, for the metal culture here evidently had its roots in a native Stone Age. 


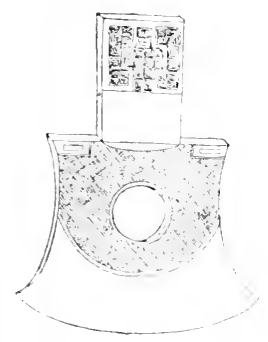

a

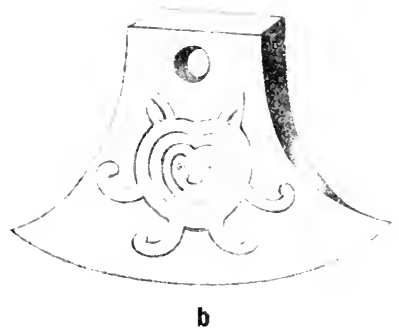

Irigs. 59 a-b.

a- Axe of bronze from China. After MORTILLET.

1:- Copper txe from Ecuator. After Gonzales Srarik.

\section{CHAPTER XI.}

\section{The Bronze Age in the Old Worla and in the New.}

We must bear in mind that the relationslip between the Copper and Bronze Ages in the Old IVorld and in the New cannot be the object of other than superficial conparison until the copper and bronze objects found in Mexico and Central America have been carefully examined. No such exanination has so far been made, or more rightly said, published. ${ }^{1}$ ) In this place, therefore, I will only state a few facts and points of view which may throw light on the question whether the American Copper and Bronze Ages developed independently or under the influence of the Old World.

1) From the illustrious Irench anthor, Dr. P.SI. RIFET, we may shortly expect a study of this kind, based on numerous andyses made by his fellow-countryman 3I. H. ABSANDACx. They have established the faet that Alexico really had a Bronze Age, which had been denied by the chief experts in the archaeology and history of that land. 
Great quantities of 'T-shaped axes have been found in $\mathrm{E}$ gypt. They date from the first up to the 26 th Dynasty, inclusive. In the beginning they were of copper and bronze, and finally of iron. From the I2th Dynasty, as Fininders PETRIE has pointed out, they closely resemble the American axes of this type (Fig. $60 \mathrm{~d}$ and Fig. $60 \mathrm{e}$ ). The hafting was also very similar in Egypt and Peru. The more rounded type of $T$-shaped axe has also been found in Egypt made of stone. Findirs PETrie holds the stone axes to be copies of metal ones.

It is, of course, a remarkable fact that the most important type of axe in S. America during the Bronze Age was also a very important type of axe in Egypt, where it was in use for thousands of years. But FLINDERS PETRIE ${ }^{1}$ ) is of opinion that we are in the presence of a parallel development in the Old World and the New, and lays stress on the circumstance that the T-shaped axe is lacking in vast intervening countries. Nevertheless we may question whether these Asiatic tracts have been subjected to sufficient archaeological study for us to be able to state that the T-shaped axe was never in use there.

Finders PETRIE ${ }^{2}$ ) derives the $T$-shaped bronze axe in its most primitive form from an older, square type of axe without a shoulder. It is not possible to trace any similar development of the $\mathrm{T}$-shaped metal axe in America. There it appears to be a copy of similar axes of stone, which, as we

1) Findiners Petrie, p. 8. "Yet this type recurs as the regular form in Pern and Central America. The entire absence of it in many intermediate lands must preclude our supposing a case of borrowing. It is one of the strong examples of an independent invention. The cause is not far to seek. In the endeavours to give a better attachment to the blade, the Iinropean peoples were working in bronze, more fusible, and better for casting, than copper. Hence they could proceed on the socket system... The Egyptian, like the Peruvian, was inventing this form in the copper stage, when hammering was the process rather than casting: hence both went on the natural lines of lengthening the blade along the landle, to give a larger bearing and a means of firm lashing."

2) P. 7 . 

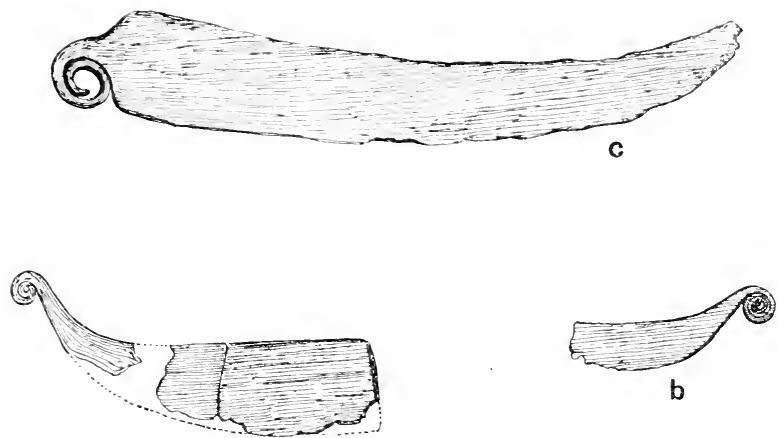

a
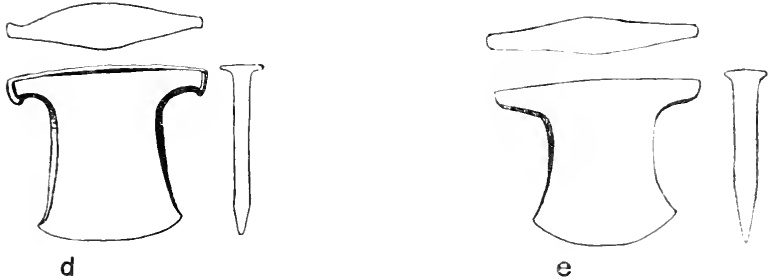

I.igs. 60 a to e

Knife from Uppland, Sweden. After Moxtintes (2), fig. i I 1 1, p 72. 'Lenght 8 c111... " "Skane, " " " " " $1112, "$ " " 4,6 " "Chancay, Peru. (;. MI. 2 I 1. 2 . (Length 15,2 ct11). T-shaped axe from Egypt. After Moxtrims (1), fig. 356, p. 915. C. 1 . - Pata, Bolivia. R. M. 06. I. I66. ${ }^{1 /}$ 
have already mentioned, had a very wide distribution there. This is, as I pointed out, under the presumption that the Tshaped stone axe in America was not originally a copy of the T-shaped metal axe, which is, however, improbable.

Another very important type of axe, the one with a little hole in it, (Fig. 59 b) finds its counterpart in bronze in the Old World (Fig. 59a). This, as ADRIEN de MORTILLET ${ }^{1}$ ) was the first to point ont, is in China. The type, as we mentioned, has been commonly fonnd in pure copper and in stone in $S$. America, and, as far as we can judge, this type of axe is older there in stone than in pure copper. Only two bronze examples have been found. In Asia, according to MORTILIET, stone axes of this type are widely distributed. They have been found in Cambodia, Laos, Burma, in the Malay Peninsula, in Malaysia, in Tongking, and in Yumnan in $S$. China. It is curious that the $S$. American copper axes of this type, like the Chinese bronze axes, are often ornamented.

These are perlaps the most striking parallels to be found in the New World and the Old between the shapes of tools or weapons. But we should also bear in mind that tweezers, the barbless fish-hook, the needle $\left.{ }^{2}\right)$, the chisel, the simple hoe-blade and the hoe (?) of the type depicted in Fig. 331, belong to the forms of copper objects that are also common to the Old IVorld and the New. To the one-edged type of knife depicted in Fig. 6oc we also find corresponding forms in Europe (Fig. 6o a, b). The primitive Tumi-knives also have their counterpart in the old $\left.\mathrm{World}^{3}\right)$.

If we go throngh all our material of weapons and tools of bronze and copper from s. America, we must confess that there is not much that is entirely original, and that to the majority of fundamental types there is something to

1) (2).

2) The eye in the needle, in a number of cases at least, seems to have been made in the same curious fashion in Peru and Egypt. (Cf. Bafsslier (1), P. 62 and Flinders Petrie, Fig. N 88).

3) See Flinders Perrif, P 5o. Fig. L I och L. 2. 
correspond in the Old World. Yet I doubt whether this is any proof that the copper and Bronze Ages arose in the New World under the influence of the Old.

In the foregoing we have been able to show that at least one type of axe was independently invented ins. America. Thas is the socketed axe, the development of which? on American soil from 'T-shaped axes and star-shaped clubheads we have been able to follow step by step. If these forms of weapons were independently invented in America, we may wonder whether this was not also the case with the other forms of metal weapons and metal tools. We have, indeed, seen that the metal culture in S. America appears to have its roots in the Stone Age. To a number of forms that we have in metal we have corresponding forms of stone, wood bone, fruit, shell, etc. It is clearly of great importance that we should try to follow the development of all the forms on American soil before we draw any conclusions about a connection between the culture of the New World and the Old because of the occurrence of similar or identical forms of weapons, tools, etc.

It must be confessed that there is considerable similarity between the metal technique of the New World and that of the Old during the Bronze Age. I will only bring to mind that such a hard invention as casting à cire perdue was known not only in the Old World but in the New in preColumbian times. Gilding and silvering were also known to the Indians. Bronze is, of course, also a very hard invention, and I must confess to finding it most remarkable that the art of alloying tin and copper should have been hit upon independently both in the Old World and the New. In the foregoing, however, I pointed out two or three things that show how greatly the Indians were interested in altering the colour of the metal, an interest which may have resulted in the important invention of bronze. As I mentioned, the occurrence of Cassiterite in the gold-washings in Bolivia perhaps drew the attention of the Indians to this heavy stone 
I think we must not underestimate the possibilities in progress to be found in such a high culture as that which developed in the west of S. America. The cultural area there had certainly a much denser population than the forests and plains east of the Andes. The development of social conditions was such that there existed a real distribution of labour: there were specialists, as for instance the workers in metal, who could thus devote all their attention to the development of their trade; there were mighty chiefs with a taste for princely magnificence, who encouraged the artisans.

I think we are underestimating the Indians of Old Peru, Central America, and Mexico, if we believe they were unable independently to invent the art of casting and of alloying tin and copper into bronze. Why should it be necessary to assume that they were not independently capable of making important inventions in the domain of metallurgy?

A very natural question suggests itself. If the Copper and Bronze Ages developed independently in the O1d World and in the New, why are there to a great extent the same forms of tools and weapons in the New World as in the Old? This could partly be explained by a parallel evolution in different localities from a similar Stone Age. A further explanation is that for identical purposes similar tools were invented in different places. Certain forms, so to speak, suggest themselves. Take the two series of development of the socketed axes. Then, again, we must remember that already in the Bronze Age the Old World had such a variety of types of weapons and tools that is not surprising we should somewhere and somewhen find forms with their counterpart in the New World.

As MIONTELIUs has emphasized, it is important to remember, if we would understand the possibilities of a connection between the Bronze Age of the Old World and that of the New, that the latter seems to be so much more recent than the former. 
Thus Montelius writes ${ }^{1}$ ), "Die Bronzezeit Mexicos und Perus ${ }^{5} 50$ Jahre nach Kristo kann doch nicht durch einen Einfluss von der Bronzezeit-Kultur Ägyptens I50o Jahre vor Kristo erklärt werden." 'There is a difference of 3000 years, and, as far as we can judge, the Bronze Age in S. America did not last very long. It was, as we have seen, at least not until Incan times that it achieved a wide distribution. Against this may be set that we dare not confidently assert that the Copper and Bronze Ages together did not last in America for more than 3000 years. Of this we know absolutely nothing.

We can, of course, easily imagine that a Copper Age may develop from a Bronze Age. All that is necessary is that in the new country, to which the knowledge of bronze came from without, tin does not occur, and the possibility of procuring tin from elsewhere does not exist, but that they have access to copper. How long the tradition can be preserved from generation to generation that by alloying another metal with copper it can be made harder, more beautiful, and more easily cast, we know nothing.

In plain terms the question reduces itself to whether a chance connection between America and the old World during the Iron Age may not have started in America a Copper and Bronze Age, the access to copper ore being much greater than that to iron ore. If a Stone Age people gets into touch with an Iron Age people acquainted with copper as well as iron, and the Stone Age people has an abundant supply of copper, but not of iron, it is quite natural for it to pass into a Copper Age, not an Iron Age. We must at least consider such a possibility when discussing the question of the relations between the culture of the Old World and the New.

It is therefore my belief that we cannot make use of the great difference in time between the end of the Bronze Age in the Old World and in the New as a decisive proof of their having developed quite independently of each other.

1) (3) P. 6 . 
It is, however, indisputable that, in combination with other facts I have adduced, this is a powerful argument in support of the theory that the Bronze Age in America developed independently of the Bronze Age in the Old World.

I must once more emphasize that we cannot solve the problem of the realitionship between the Bronze Age in the Old World and in the New until we are really acquainted with the metallurgy of Central America and Mexico. We must know whether the Bronze Age is older or younger in S. America than in Central America and Mexico, to what extent the metal culture developed independently or otherwise in different parts of America. As long as I was unacquainted with Rivet and ABSANDAUx's studies of copper and bronze objects from Mexico, and, following LEHMANN, ${ }^{1}$ ) believed that they had not reached a Bronze Age in Mexico in pre-Columbian times, I was inclined to assume that the Chiriqui Bronze Age arose under the influence of Peru. The bronze objects that HoL MEs') and MAC CURDY'3) have found in Chiriqui are bells (Fig. 58 , e f). Similar ones are found on the Peruvian coast, and it is very remarkable that among the articles carried by traders whom BARTOLOMÉ Ruiz met off the coast of Ecuador there should have bein precisely such bells, proving that a considerable trade en these objects was carried on along the west coast of S. America. ${ }^{4}$ ) The occurrence of bronze in Mexico is, of course, not precluded by its having been through commercial connections with Peru or Ecuador that the knowledge of bronze was first introduced into Chiriqui. In that case bronze must have been late in Chiriqui, presumably just before the Discovery. As we know, it was not until Incan times that bronze came into general use on the coast of Peru and in Ecuador.

1) P. 678 .

2) (I).

3) P. I97.

4) Samaxos, p. 197 . 


\section{List of Objects Analysed.}

In this list are only included analyses specially made for this work, and a few that are not to be found in the lists of DE: CréqHi-MoNTFORT \& RIVET, and JiJón Y CAAMAÑo.

I. Analyses specially made for this work by Dr ArMströn, Professor (G. BoDmax and Mr FLOBERG, (all of Gothenburg), Professor I)r. (;. Ratgen (Berlin) and at the technical bureau of Mr LANDIN (Stockholm).

A. Objects found in grave-houses, or so-called chulpas, and burial caies in the border districts of Pert and Bolizia. $\left.{ }^{1}\right)$

Grave I. Pelechuco.

This grave was found close to the bridle-path leading from the high platean to Pelechnco. In the chulpa were found nouldered remains of five skeletons whose position to each other could not be determined, since the dead had not been buried, but simply put or laid in the chulpa. Nor conkl it be determined to which skeleton any of the objects belonged that were found in the chulpa.

1) I more detailed description of these graves occurs in my paper \#. trkeologiska undersökningar i I'erus och Bolivias grïnstrakter 1004 (1) $(10.5 . ")$ 


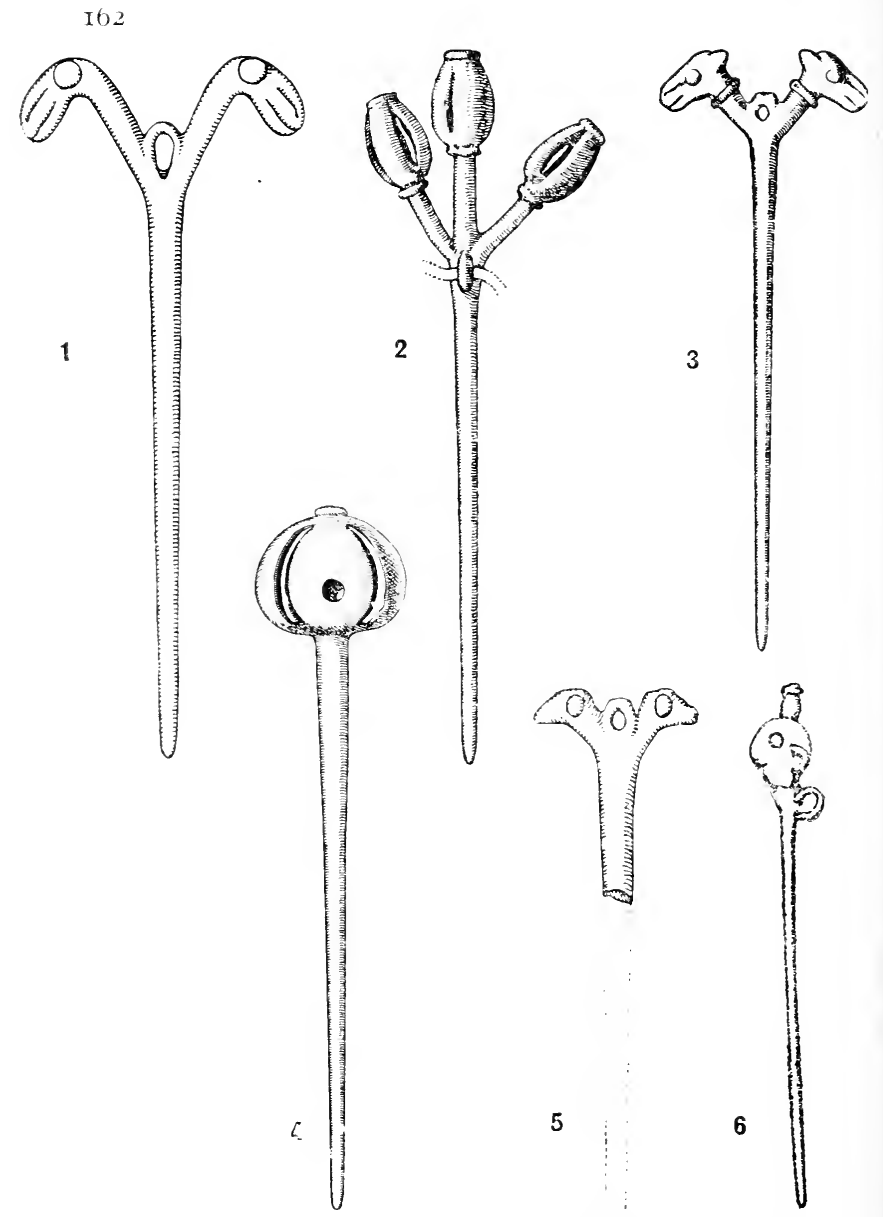

Figs 61,1-6,1,6. Topus from Bolivia, Analysed for this work.

1. Pelechuco, R. M. of 1. 335, 1/1.

2. Queara, " " $366,2 / 3$.

3. Velechuco, $" \# * 316,1 / 2$.

4 . " " 317 , "

5. Queara, " " $\quad 349,1 / 1$.

6. " $"$ " $361,1 / 2$ 
Four copper topus were found in this grave. In three of then the proportion of tin has been determined.

I. R. M. 06. I. 3I6. I.ig. 6I, 3. The head of the topu shows two llama heads. Proportion of tin, $+49 \%$. (Bomman).

2. R. M. 06. I. 3I7. Fig. 6I, 4. The head may possibly be meant to represent a flower-bud or a fruit. It contains a little stone, so that the topu has probably also served as a rattle.

Proportion of tin, $5.88 \%$. (BODMAN).

3. R. M. o6. I. 3I9. Fig. 62 a. Topu with triangular, somewhat worn top, and hole slightly askew.

Proportion of tin, $2 \%$ \%. (BODMaN).

Grave 3. Pelechuco.

This grave, situated to the right of the Pelechuco brook, is of the sane type as Grave I, but covered with five slabs of slate, while the outer walls were covered with a now partially removed wall of small stones. The chulpa contained two much mouldered skeletons. The older one had evidently been disturbed and displaced when the younger one was inserted. The objects lay under the older skeleton.

In this grave was found a bronze topu.

4. R. M. 06. I. 335. Fig. 6I, r. The head consists of two llama heads pointing away from each other.

Proportion of tin, 7. II $\%$. (BODMAN).

Grave 2. Queara Valley.

The chulpa was partly ruined (roofless), but not excavated. Unlike the chulpas I described from the Pelechuco Valley, this consists of a square wall provided with an opening, which had been closed with a lamina of slate. In this grave were found the remains of ten much monldered, shallow-lying skeletons. Among the objects fonnd in the grave were six copper topus. One has been fully analysed, and in another the proportion of tin has been determined.

5. R. M. o6. I. 34s. Fig. 48, I2. Topu in the shape of two flower-buds (?)

Proportion of tin, $4.9 \mathrm{I} \%$. (BODMAN). 
6. R. M. o6. I. 349. Fig. 6I, 5 Broken topu. Possibly represents the heads of llamas. The analysis gave the following result:

$\begin{array}{lrr}\text { Copper } & \ldots \ldots \ldots \ldots \ldots \ldots \ldots & 69.22 \% \\ \text { Tin } & \ldots \ldots \ldots \ldots \ldots \ldots \ldots & 6.2 \mathrm{I} \% \\ \text { Antimony } & \ldots \ldots \ldots \ldots \ldots & 2.67 \% \\ \text { Bismuth } & \ldots \ldots \ldots \ldots \ldots \ldots & 1.46 \% \\ \text { Silver } & & \end{array}$

Gold in an indeterminable quantity.

Silica (traces).

Remainder carbonic acid, water chemically combined and oxygen, respectively. ${ }^{1}$ ) (LANDIN.)

Grave 4. Queara Valley.

This grave was fonnd on the right of the road leading from Queara to Mojos, not far from Grave 2. It is a cave formed by a large overlapping stone. The entrance had been walled over. In the grave were found remains of nine shallow-1ying skeletons, and five copper topus together with a little stone necklace-bead. The proportion of tin in two of them has been determined.

7. R. M. o6. I. 357. Fig. 48,2 . 'Topu of same type as 5 . Proportion of tin, I.95\%. (BODMAN).

8. R. MI. o6. I. 358. Fig. 48,6. Topn Pin of same type as foregoing.

Proportion of tin, $2.67^{\circ}$. (BoDMAN).

Grave 8. Queara Valley.

Grave 8 is a cave under a big stone, near Grave 4 . In it I fonnd I6 skeletons, three copper pins, etc. The proportion of tin in one of the pins has been determined.

9. R. M. o6. I. 36r. Fig. 6r, 6 Topu. The head possibly represents a himan head bearing something. Proportion of tin. $9.02 \%$. (BODMAN).

Grave I2. Queara Valley.

Burial cave under a big stone. In the grave were found

1) In analysing this object they eridently did not remove the oxidised portion. 
rennains of eight shallow-lying skeletons. One cranium was trepanned. In the grave I found a bronze topu, etc.

Io. R. M. o6. I. 366. Fig. 6 I, 2. Topu. 'The heads look like flower-buds.

Proportion of tin, $7.87 \%$ (Bomman.)

Grave If. Queara Valley.

This is a huge grave under an overhanging piece of rock not far from the farm on the left side of the Queara brook. Owing to indistinctness in my notes, I cannot give the exact number of skeletons in this grave, but there were close upon 200. They had not been buried, but had been piled $u$, in a mass, probably in bundles which afterwards mouldered away. With all these skeletons very little handiwork was found. One of the crania had been trepanned. In this grave I found four copper topus. 'The proportion of tin has been determined in one case.

I I. R. M. 06. I. 37 I. Fig. 49.5. 'Top11. The head consists of a round, flat disk with a central hole.

Proportion of tin, $7.95 \%$. (Bodman).

Grave I5. Queara Valley.

This is a cave of the same kind as the foregoing, and is situated near it. It contained remains of about 50 shallowlying skeletons, and very few objects with them: anong these was a bronze pin.

I2. R. M. 06. I. 399. Fig. 48, I3. 'Topt. 'The head is a round, flat disk with a central hole.

Proportion of tin, $5 \%$. (Bodman).

Grave I. Capamitas.

(Capamitas is situated where the Rio Caripuna joins the Rio Queara.)

This is a sonewhat inaccessible cave, formed by an overhanging rock. Part of the cave was partitioned off by a long stone wall. Inside this were found scanty remains of the skeletons of two elderly persons, and outside this parts of a child's skeleton. Inside the wall I found three copper topus, and a similar one ontside it. 'Those pictured here, the 
proportion of tin in which has been determined, were found inside the wall.

I3. R. M. o6. I. 404. Fig. 49, 3. Topu The heads resemble flower-buds.

Proportion of tin, $7.66 \%$ (Bodman).

I4. R. M. 06. I. 405. Fig. 49, 6. 'Topu of same type as former. It has weathered through exposure.

Proportion of tin, $8.87^{\circ}$ '. (Bodman).

Grave 2. Corani Valley.

Grave 2 is a cave under an overhanging rock. It was quite intact, and contained two layers of skeletons sitting over each other. All the handiwork was found in the upper layer. Among them was a bronze topu.

I5. R. M. 06. I. 52 I. Fig. 48, 9. Topu1.

Proportion of tin, $4.08 \%$. (BODMAN)

B. Bronze objects from the border tracts of Peru and Bolivia obtained by barter from Indians living there, who had come across most of them while working in their fields.

\section{Axes.}

I6. R. M. 06. I. I65. Fig. 48, 8. Quiaca. 'I'in ${ }_{0}^{\circ}, 3.29$.(Bodmax). I7. R. M. 06. I. I67. Fig. 48, I6. Quiaca. "5.20. " Is. R. M. o6. I. I66. Fig. 48, 5. Pata. " 2.43 " " I9. R. M. o6. I. I68. Fig. 48 , II. Chusecani " 4.67 . "

"Tumis".

20. R. M. 06. I. I73. Fig. 48, I4. Ollachea.

Tin $\%, 5.04$. (BODMAN)

2I. R. M. 06. I. I75. Fig. 48, 7. Ollachea.

$\begin{array}{lrr}\text { Copper } & \ldots \ldots \ldots \ldots \ldots \ldots \ldots & 96.5 \\ \text { Tin } & \ldots \ldots \ldots \ldots \ldots \ldots \ldots \ldots & 3.4 \\ \text { Lead } & \ldots \ldots \ldots \ldots \ldots \ldots \ldots \ldots & \text { traces. }\end{array}$

Free from arsenic, zinc, bismuth, and antimony. (AI $\mathrm{AI}-$ STRÖM.)

22. R. M. 06. I. I 76 . Fig. 48, 4. Ollachea.

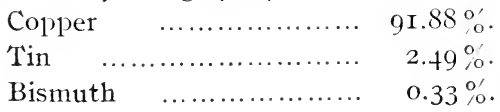




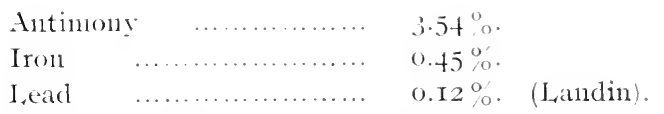

23. R. M. o6 I. I77. IFig. 48, I. Quiaca. 'Tin \%, I.50. (Bommax).

Blade of a hoc.

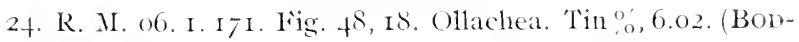
MaN.)

Rough stage of hoe-blade (?)

25. R. II. o6. I. I72. Fig. 4S, I5 Ollachea.
Copper
$9+6^{\circ}$.
Tin
$5.4 \%$

Free from lead, arsenic, zinc, antimony, and bismuth. (AlMiströni).

c. Bronze objects found in various parts of Bolivia.

26. G. M. 15. 2. 22. Fig. 62 Axe. Pulquina.

Copper

$86 .+7 \%$.

Tin

I3. $42 \stackrel{\circ}{\circ}$. (Floberg).

27. R. M. R. 24. Fig. 62 Axe. Samaipata.

Copper

Tin

I,ead

Sulphur
$97.8 \%$

$0.7^{\circ}$.

$0 .+\%$

$0.5 \%$.

Free from arsenic, zinc, antinnony, and bismuth. (ALMSTRÖM).

28. G. II. I5. 2. I5. Fig. 62. Chisel. Chiton. 'Tin \% , 7. I2. (BOD11.

29. G. M. 15. 2.,32. B. Fig. 62. Axe. Peres. (Mizque). Tin 3 \% 49 (Bodmax.)

30. G. II. I5. 2. 21. Fig. 62. Part of round disk. Pulquina.

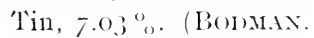

31. G. MI. 15. 2. Ios. A. I'ig. 62. Axe. corendo. 'T'in o, 4.67. (BODMAN.)

26-3 I were oceasional finds.

D. Find in a grave-urn, finta Rosa, Province of Stara, north of sianta Cruz de la sierra, Bolivia. There is a detail- 
ed description of the grave in my paper, "Urnengräber, etc." In the same uril were found, among other things, three small round silver disks.

32. R. M. O. 73. Fig. 62. Round disk.

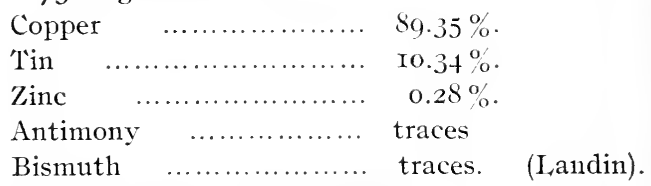

E. Find in a grave at Kaipipendi in the Chiriguano territory in S. E. Bolivia.

33. R. M. K. 29. Fig. 62 Piece of a fillet. (?) Much crumbled.

Copper $85.9 \%$.

The remainder chiefly carbonic acid and water, as carbonate and hydroxide, respectively. (I andin).

F. Copper and bronze objects found on the Peruvian coast.

The objects were bought for the Museun at Gothenburg through Dr. F. X. Weizinger of Munich, and collected in Peru by Dr. F. Gaffron. No further details are known about the circumstances of the finds. The local statements seem to be reliable.

34. G. M. 2I. I. Ir. Fig. 34 d. One-edged knife. Súpe.

Copper $\quad$................. $94.7 \%$.

Tin $\ldots \ldots \ldots \ldots \ldots \ldots \ldots \ldots . . . . .6 .6$.

Free from zinc. (Almström).

35. G. M. 2I. I. 5. Fig. 33 p. Hoe. Chancay.

$\begin{array}{lrr}\text { Copper } & \ldots \ldots \ldots \ldots \ldots \ldots \ldots & 98.2 \% \\ \text { Antimony } & \ldots \ldots \ldots \ldots \ldots \ldots & 0.7 \%\end{array}$

Free from arsenic, tin, bismuth, and zinc. (ALMström.)

36. (․ .I. 21. I. I4. Fig. 33 i. l'weezers. Súpe.

Free from tin. (Araströn.)

37. (․ M. 2 I I. 6. Fig. 33 1. Blade of a loee. Chancay.

Copper $95.62 \%$.

Arsenic

$+27{ }_{0}^{\circ}$.

Autimony

$0.08 \%$

Firee from tin, silver, lear, zinc and bismuth. (Alaströn.) 
38. G. M. 2I. I. 7. Fig. 34 c. "I'umi». Chancay.

Proportion of tin, $4.6 \%$. (Almströn).

39. G. II. 2I. I. 4. Fig. 33 c. "T'tumi". Chancay.

Firee from tin. (Almström).

fo. G. M. 2I. I. 2. Fig. 33 h. One-edged knife from Chancay with a small spiral handle.

Copper $97.7 \%$

Firee from tin and zinc. Contains traces of iron. (ALMSTRöm) fI. G. M. 2I. I. I5 Fig. 34 f. Object in form of a alligatorhead. Huacho.

Proportion of tin, $7,2 \%$ (Almström.)

4I b. G. M. 2I. I. 8. Fig. 65. Rattle. Súpe.

Upper half ...... I00,20\% of Copper.

Lower " ...... I00, $15 \%$ " "

Free from gold, silver, tin, antimony, lead, arsenic, nickel, iron and zine. (Alaströм).

G. Objects from the Peruvian coast obtained by exchange from the Museum für Völkerkunde in Berlin. No further details are known about the circumstances of the finds. 42. G. M. I6. 9. 26I. Fig. 34 d. Tweezers. Pachacamac. Proportion of tin, $5.5 \%$. (Almström.)

43. G. M. I6. 9. 272. Fig. 34 b. 'Tweezers. Pachacamac. Proportion of tin, $3.4 \%$ (Almström.)

44. G. M. I6. 9. 265. Fig. 33 j. Tweezers. Pachacamac. Free from tin. (Alaströ̈.)

45. G. M. I6. 9. 267. Fig. 33 k. 'Tweezers. Pachacannac. Free from tin. (Alasström.)

H. 46. Native copper from Corocoro (Bolivia).

After the incrustation had been renoved, the copper contained $\mathrm{I}_{5} \%$ of substances insoluble in nitric acid. It was free from tin, gold, silver, and lead. (Aluström.)

I. Copper objects from the Peruitan Coast at the Museum für Völkerkunde in Berlin.

47. V. A. 21810. Fig. 33 d. 'Tumi, 'Trujillo.

Free from tin (RATGFN.) 
48. T. A. 2ISII. Fig. 33 e. Tumi, Trujillo.

Free from tin. (RATGer.)

49. V. A. 2528 I. Fig. 33 g. Knive, Chuquitanta.

Contains arsenic, free from tin. (RATGEN.)

50. V. A. 25284 . Fig. 33 f. 'Tumi, Chuquitanta. Free from tin. (RATGEN.)

51. V. A. 26273. Fig. 33 a. Tumi, Lima.

Contains arsenic, free from tin. (RATGEN.)

52. V. A. 26274 . Fig. 33 b. Tumi, I,ima.

Contains arsenic, free from tin. (RATGEx.)

J. Copper and bronze objects from Bolivia at the MI1sen1m für Völkerkunde in Berlin.

53. V. A. 12672 b. Fig. 2 F. Bar in shape of a axe, Huachu, Omasuyu.

\begin{tabular}{|c|c|c|}
\hline Copper & $\ldots$ & $82.07 \%$ \\
\hline Tin & & I $7.78 \%$ \\
\hline Lead & … & $0.05 \%$ \\
\hline ron & . . & $0.07 \%$ (RATGEN.) \\
\hline
\end{tabular}

54. V. A. I279I. Fig. 42 aa. Axe, Copacabana.

Copper

Arsenic

Iron
$96.36 \%$

$0.5 \mathrm{I} \%$.

$0.07 \%$.

Trace of Coal and sand. (RATGEN.)

55. V. A. I5625. Fig. 47 a. Axe, San Blas, Tarija.

Copper

Tin

Iron

Trace of Cobalt. (RATGEN.)
$93.70 \%$

$6.15 \%$

$0.29 \%$.

K. Copper objects from Argentina at the Museum für Völkerkinde in Berlin.

56. V. A. 4057. Fig. 2 A. Cramp, Andalgala.

'Traces of tin, lead and arsenic. (RATGEN.)

57. V. C. I656. Fig. 4, Ic. Axe, Ia Toma, Catamarca.

Copper

Iron

Trace of Cobalt. (RATris).
$99.8+\%$

$0.07{ }_{0}^{\circ}$. 
58. V. C. $165^{8}$. lig. 43 , I b. Axe, I a Toma, Catamàra.

'Traces of tin? (Alaström.)

II. Analyses published by Eric ion Rosen (p. 365)

59. Small bell. Iig. 43,8 . Casabindo, Jujuy, Argentina.
Copper
$06.36 \%$
Tin
$0.64 \%$.

6o. Chisel. Fig. 44, I5. Morohuasi, Jujuy, Argentina.

Copper

$92.47 \%$

Tin

$7.53 \%$

6r. Chisel. Irigr. 47 c. Tarija, Bolivia.

Copper

$91.85 \%$

lin

$8.15 \%$

62. Bronze disk I'ig. 47 b. Tarija, Bolivia.

Copper $\quad \ldots \ldots \ldots \ldots \ldots \ldots \ldots . . .63 .10_{0}^{\circ}$.

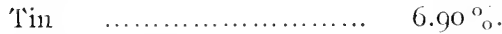

63. Rod. Tarija, Bolivia.

Copper $\quad$................... $99.93 \%$

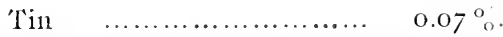

III. Analysis publishcd by Boman (2).

64. Small copper disk. Fig. 4, , I7. 'Tinti. Salta.

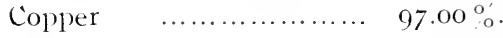

'Tin ...................... $2.9 \mathrm{I}^{\circ}{ }_{0}$.

IV. Analyses published by Debcnedetti (2).

65. Snall bell. Fig. 44,8 . San Juan.

\begin{tabular}{|c|c|}
\hline per & $\ldots \ldots \ldots \ldots \ldots \ldots$ \\
\hline Tin & . \\
\hline Iron & \\
\hline
\end{tabular}

66. Netal remains in crucible. San Juan.

Copper $\quad \ldots \ldots \ldots \ldots \ldots \ldots . .65 .05 \%$.

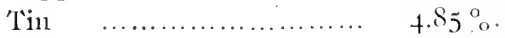

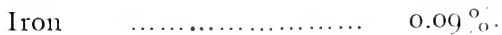

V. Analysis published by I'crneau (2).

67. "Tintinnabulum" from Peru. (See Fig. I3, D, E, I) of Copper with traces of stuphur and iron. 


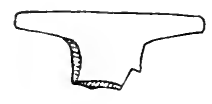

A

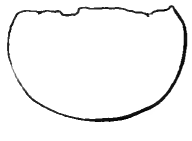

$\mathrm{D}$
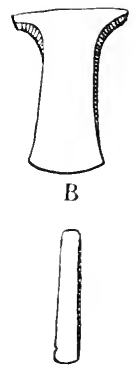

$\mathrm{E}$
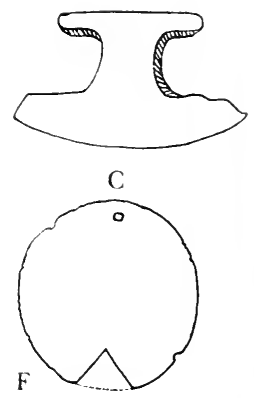

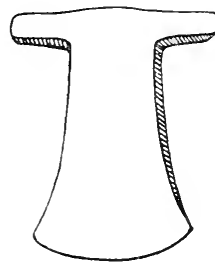

G

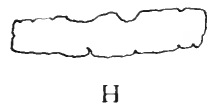

Figs. 62 a $-62 \mathrm{~h}$. Objects from Bolivia analysed for this work. 1/4.
a-Axe, Samaipata,
R. M. R. 24 .
b- " Peres Mizque,
(i. M. $15.2 .32 \mathrm{~b}$.
c - " Covendo.
" " "I08 a.
d-Disk, Pulquina, Mizque, " " " 2 I.
e-Chisel, Chilon, " " " 15.
f - Disk, Sara, R. M. O. 73.
g-Axe, Pulquina, G. M. I5. 2. 22.
h ... Iillet(?) Caipipendi, K. II. K. 29 . 


\section{Appendix A.}

An examination of the hardness of 9 bronze implements from Peru and Bolivia, submitted by Baron Erland Nordenskiöld.

The objects were received for examination in I)ecember, 1920 .

Their appearance and dimensions can be seen from figs. $63 \mathrm{I}-63 \mathrm{IX}$.

The aim of the examination was (I) to determine the hardness of the objects in their various parts, and (2) to establish, if possible, whether the hardness determined in each special case was mainly a result of the chemical composition, or whether cold-hammering had contributed to produce same.

By cold-hammering is usually meant working on an object by hammering or the like at the ordinary temperature. As is well known, this treatment can considerably increase the hardness of a metal. Hot-hammering above a certain temperature, the so-called lowest annealing temperature, has not this effect on the hardness of a metal. Hot-hanmering, however, may, of course, be continued during the cooling below this temperature, whereby hardening by cold-hanmering ensues. 'The expression 'cold-hammering' should therefore be interpreted in its widest significance, so as to include this last condition. 'To decide whether cold-hammering had taken place in this sense, hardness tests have in certain cases been applied, first in the original state, and then after suitable annealing had eliminated the hardening effect of any possible cold-hammering. 
Where annealing was undertaken, it was performed in such a way that the object was packed in cast iron filings to prevent oxidation, and heated in a gas-furnace up to $750^{\circ}$ c., which temperature was kept for I $_{5}$ minutes, whereupon cooling was effected in the air.

In order to compare the results obtained on the bronze implements, hardness tests were carried out on a series of 3 axes, newly cast from the model of an old axe from Peru, in pure copper, in bronze with $5 \%$ and in bronze with $10 \%$ of tin, first in the cast state, then after various stages of cold-hammering, and then after annealing both cold-hammered and not cold-hammered parts of same. These axes were also submitted to us by Baron Nordenskiöld.

For further comparison the hardness has been determined on electrolyte copper, as rolled and annealed and after various stages of cold-hammering.

Choice of method in testing hardness.

The methods of testing hardness that can be taken into consideration here are two, viz. BRINELL's method and sHorE's scleroscope method. The principle of the last named consists in letting a small dropweight fall from a certain height and strike the surface of the object so that it rebounds to a certain reduced height, which is the measure of the hardness of the object. This method has the advantage of only making insignificant marks on the surface of the object, but its results are, especially with thin objects, far too dependent on the thickness and mass of the object, as well as on the manner in which it is supported. It has therefore not been considered suitable in this case, where a comparison was to be made, for instance, between the thin edge and other thicker parts of the same implement.

The hardness has therefore been determined by BRINELL's method, which proceeds in the following way. A hardened steel ball, usually io $\mathrm{mm}$. in diameter, is slowly pressed under a given pressure, generally $3,000 \mathrm{~kg}$., against a plane ground surface of the object to be tested. This 
produces an impression in the slape of a splerical calotte; the diameter of the calotte is measured by means of a neasuring mieroscope, and the hardness number is obtained by dividing the pressure used by the curved surface of the impressed calotte. By reason of the small thickness of the object, however, this test had to be modified inasmuch as smaller balls and smaller loads were enployed.

The following combinations have been used:

$5111 \mathrm{~m}$. ball and a load of $750 \mathrm{~kg} . \quad \begin{aligned} & \text { the same relation be- } \\ & \text { tween the load and the } \\ & \text { square of the diam. of the }\end{aligned}$ $2.5 \mathrm{~mm}$. ball and a load of Igo kg. | ball as with ro $\mathrm{mm}$. ball and a load of $3,000 \mathrm{~kg}$. and (with the cast axes)

$5 \mathrm{~mm}$. ball and a load of $250 \mathrm{~kg}$.

It should be observed that only numbers obtained with the same size of ball and the same load are comparable between themselves; the values obtained with a $5 \mathrm{~mm}$. ball are, however, to be regarded as more accurate than those obtained with a $2.5 \mathrm{~mm}$. ball.

'To judge the significance of the hardness numbers obtained we may quote the Brinell numbers for some common metals:

$\begin{array}{ll}\text { soft iron } & 70 \text { to } 80 \\ \text { hardened steel } & \text { about } 700 \\ \text { annealed copper } & \text { about 5o } \\ \text { cast tin } & 8 \text { to Io }\end{array}$

All the chemical analysis figures given in the following were communicated by Baron NORDENskiör,D.

RESUL'TS OF 'TES'TS.

I. Bronze implements irom Peru and Bolivia.

The results will be found in 'Table I and Figs $63 \mathrm{I}-63 \mathrm{IX}$.

II. Cast Axes.

The results appear from 'Table 2 and Figs 64. 
176

All the axes were porous in the metal, so that the hardness numbers for not cold-hammered parts are toolow. They have been placed within parentheses.

In the manner illustrated by Fig. 64, the lateral arms, with a thickness as cast of $12,8 \mathrm{~mm}$., thinning out to $9.0 \mathrm{mmm}$ towards the end of the axes, were cold-hammered, both by hand, and by being hydratlically pressed to different thicknesses, the hardness being then determined on the step-like ledges obtained. From this can be seen how the hardness increases with coldhammering when the tin content is 0,5 and 10 per cent respectively. The hammering of the copper axe failed owing to its porosity.

\section{Electrolyte copper.}

A flat bar of $6 .+\mathrm{mm}$. in thickness was annealed and then hammered cold to varions thicknesses. The following hardness numbers were obtained:

Annealed Hammered to a thickness of

Brinell
number $\left\{\begin{array}{ccccc}50 & 6.2 \mathrm{~mm} . & +3 \mathrm{~mm} . & 3.5 \mathrm{~mm} . & 2.5 \mathrm{~mm} \text {. } \\ 50 & 69 & 8_{9} & 9 \mathrm{I} & 93 \\ 55 & 64 & 8_{\mathrm{I}} & 8_{3} & 86\end{array}\right.$

The upper figures refer to a $5110 \mathrm{~m}$. ball and a load of $750 \mathrm{~kg}$. "lower " " " 2.5 " " " " I 80 "

\section{Summary.}

'The results of the investigation may be summed up as follows.

An addition of $5 \%$ of tin to the copper increases the hardness, as determined by BRINELL's method, from 45 to 50 11p to abont 70 , an additional $5{ }^{\circ}$ of tin increases the hardness to about 85 . 'These figures apply to the annealerl metal. By cold-hammering the hardness of copper and bronze can be increased to $2^{1 / 2}$ to 3 times as high a value, expressed in BRINEIr, units, the increase of hardness being here dependent, of conrse, on the degree of coldhammering, 
which, practically speaking, is equivalent to the relative decrease in thickness.

As to the bronze inmplements from Peru, they have revealed very varying degrees of hardness in different parts. The edge, wherever it could be tested, was considerably harder than the rest of the tool. This nust be attributed to the circumstance that these implements were hammered at a temperature below the minimum annealing temperature for the alloy in question, either by hot-hammering, in which case the implement cooled down below this temperature while being hammered, or by hammering at the ordinary temperature. 'This conclusion is confirmed by the fact that the hardness diminished considerably on annealing. An exception is the "blank of blade of a hoe", No. 5, which lacks an edge in the true sense. 'This showed a fairly even hardness all over the surface, and the decrease on annealing was of small account. From this we may conclude that the implement was either not hammered after being cast, or was hammered at a high temperature.

Gothenburg, May 26th, I92I.

I,aboratory of the A.-B. Svenska Kullagerfabriken S. K. I: (signed) AxEI, HultgreN. 


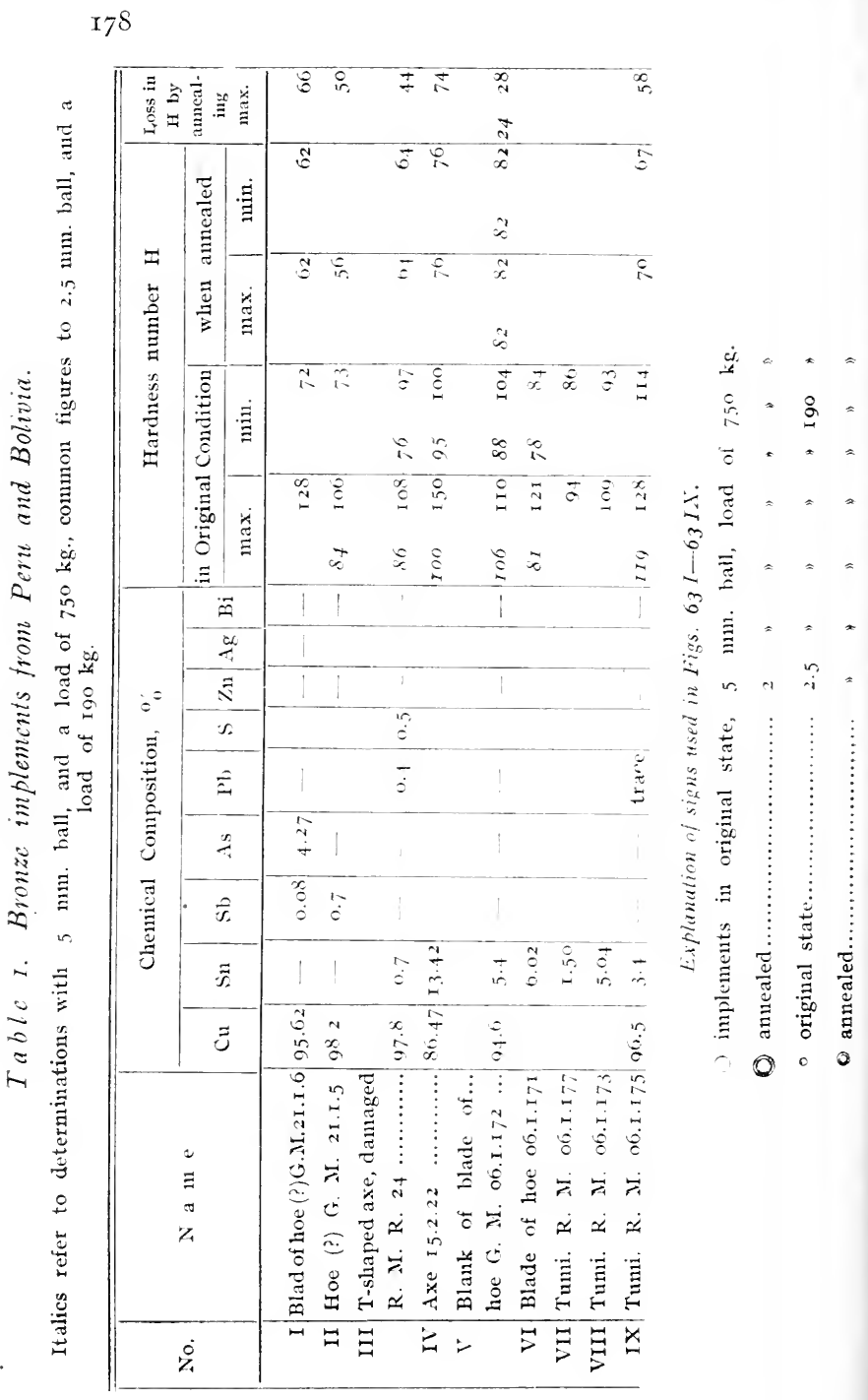



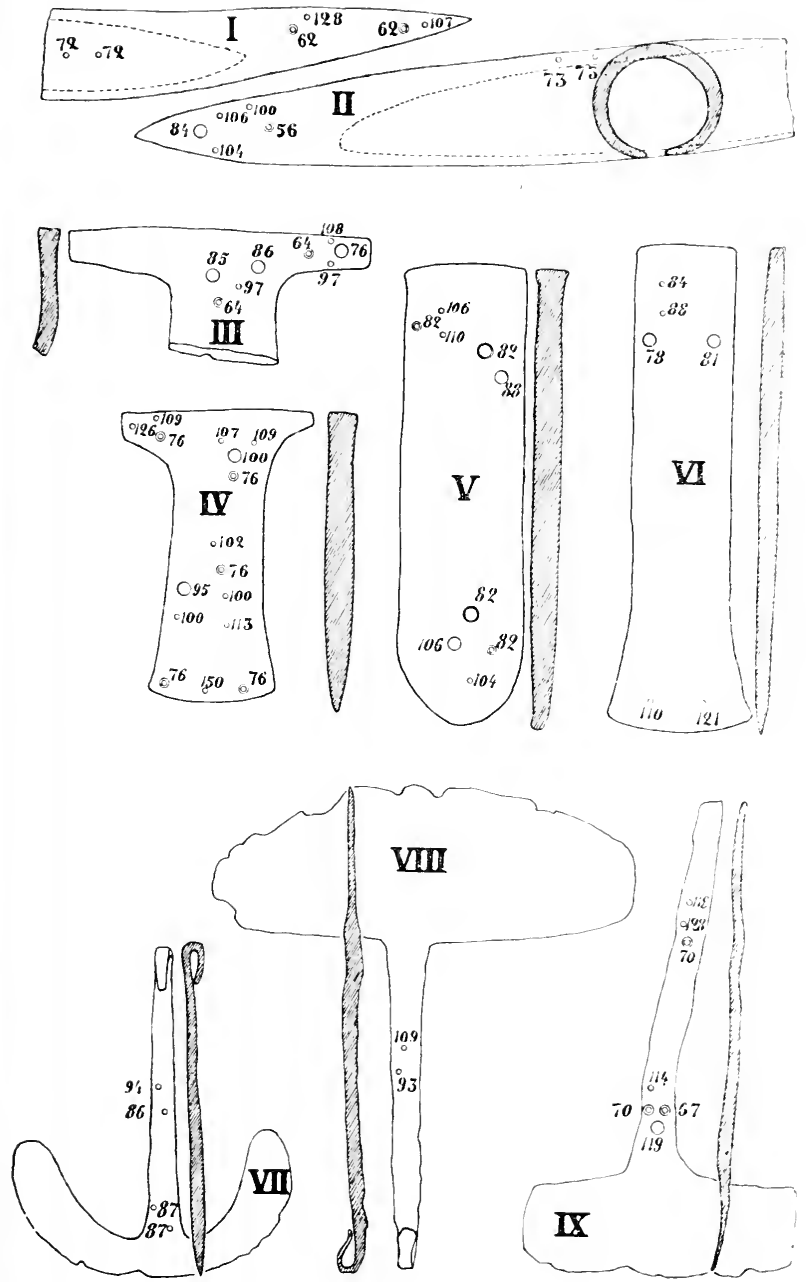

Figs. $63 \mathrm{I}-6_{3} \mathrm{IX}$. (Sce Table I). 

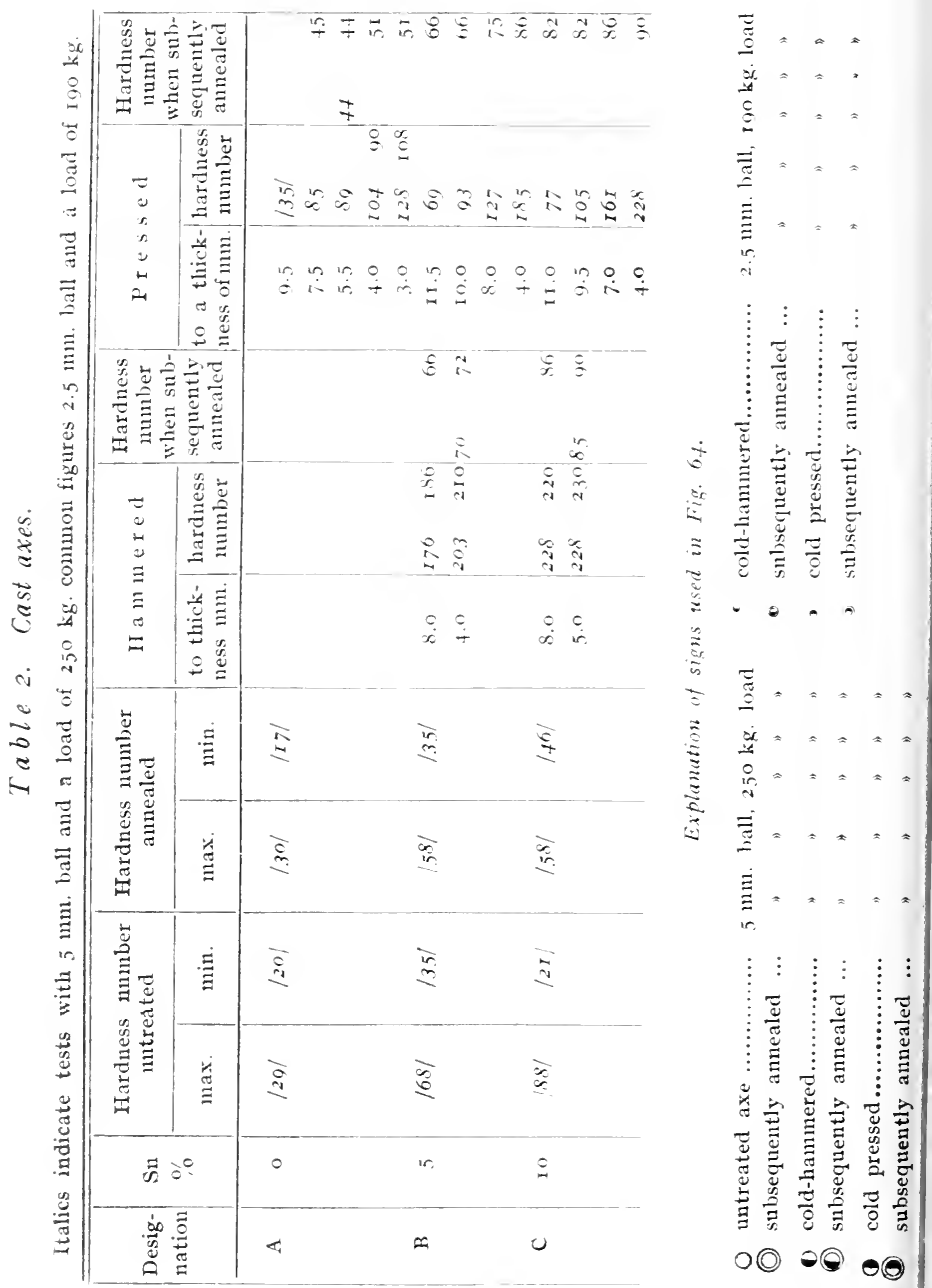

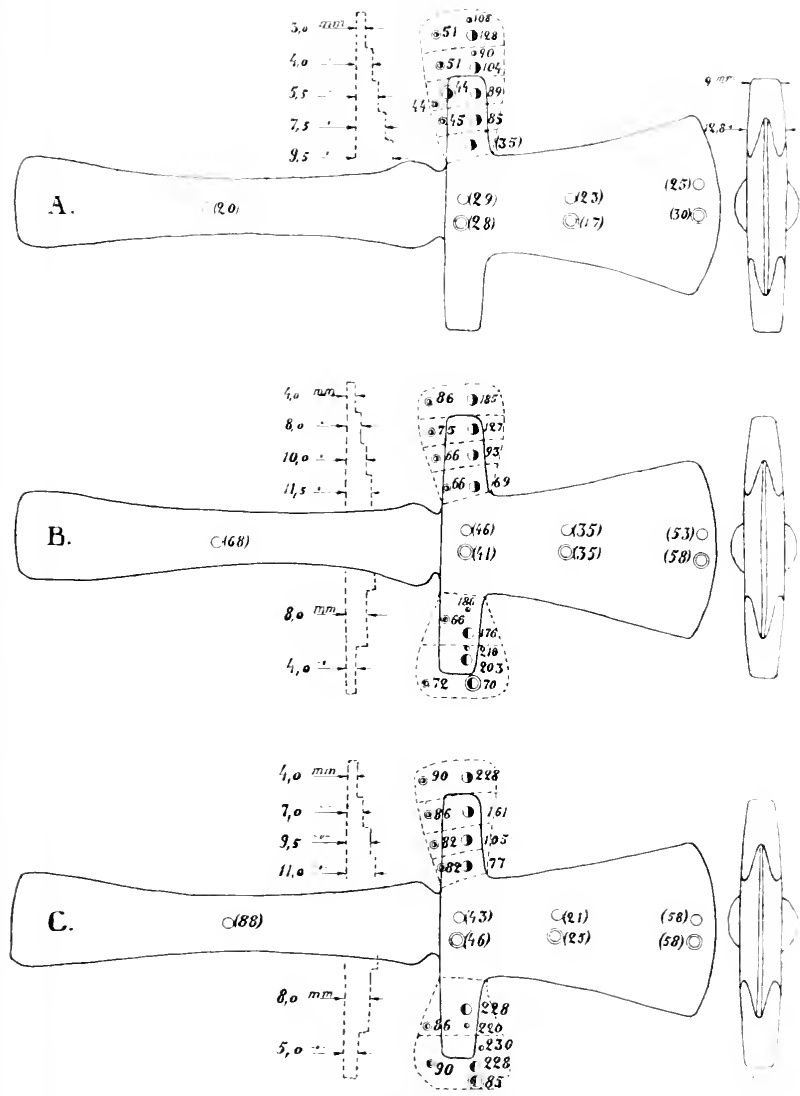

Fig o4. (S.re Table 2). 1;, 


\section{Appendix B.}

Investigation of a pre-historic copper object from Peru, a rattle, marked G. M. 2I. I. 8., submitted by Baron E. NORDENSKIÖLD, Intendant at the Gothenburg Museum,

The object, reproduced in its natural size in Fig. 65 , is a rattle found at sùpe on the Peruvian coast. ${ }^{1}$ ) It was probably used for magic practices in a similar way to that in which rattles are still used by Indians at the present time.

The rattle (Fig. 65), which has a very symmetrical shape and is carefully made, consists of a bulb and a handle. The bulb is made of two bell-shaped halves of hammered or "spun" copper plate, circa $0.5 \mathrm{~mm}$. in thickness, joined together along the line A-A. Four small holes are symmetrically arranged in the upper half. The lower half had been prolonged into a short tubular neck that encloses the upper end of the handle and thereby forms the connection between bulb and handle. The upper part of the handle is round, the lower flat. The former has a hole right through it. The rattle contained two small copper balls of a diameter of about $5 \mathrm{~mm}$. The surface of the rattle was corroded and verdigrised. The joint at A-A had opened along circa $3 \mathrm{~cm}$. Apart from this the seam was not discernible, and no indication of folding or of soldering was to be observed.

1) (Editor's note.) No particulars are known about the circumstances of the find. 
I83

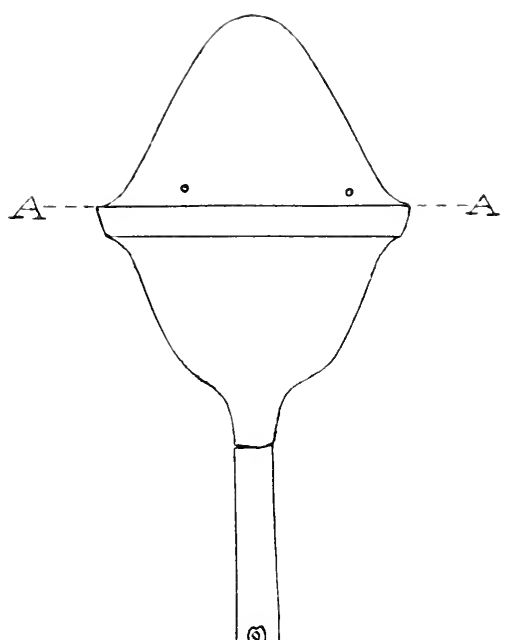

()

Fig. 65.

Rattle of pure copper found at supe on the Peruvian coast. G. M. 2 I, I. S. $\$ / 5$. 
The object of the investigation was to ascertain how the joint had been effected. To this end a strip was cut out right across the joint. This section was ground, polished, etched in a solution of basic copper ammonium chloride in water, and examined under the microscope. (See IFig. 66, photographs I \& 2.)

The structure consisted of a matrix of copper in both halves. In the upper one occurred quite a number of small round particles of cuprous oxide. The lower only contained a small quantity of such inclusions. The copper grains showed slip-lines pointing to cold working. The joint was a welded one, revealing in certain parts of its length (seen in cross-section) perfect metallic continuity between the two parts, in others, especially at the outer and inner edges, incomplete welding. Apart from copper there was no metallic constituent (as from soldering) in the structure. At the inner edge of the joint the lower half showed a distention or wale.

Fig. 66, I shows the cross-section of the joint after rather strong etching (magnified by 50). It will be seen that the actual line of the joint is surrounded by a zone more resistant to the etching, pointing to a change of chemical composition of the copper in this part, possibly due to dissolved oxygen absorbed in the welding. Similar zones also surround the cuprous oxide inclusions. The said wale contains a cavity. Fig. 66, 2 (magnified by I00) was taken after the section had been somewhat ground down. In this case the etching was weaker. The perfect continuity between the halves can be plainly seen here, and was confirmed by examination at r20o times magnification. The wale in this section is without porosity.

After the strip had been removed, the interior of the rattle could be examined, whereupon it was found that the wale extended all round and was very even.

From the examination the conclusion can be drawn that in all probability the two halves of the rattle had been 

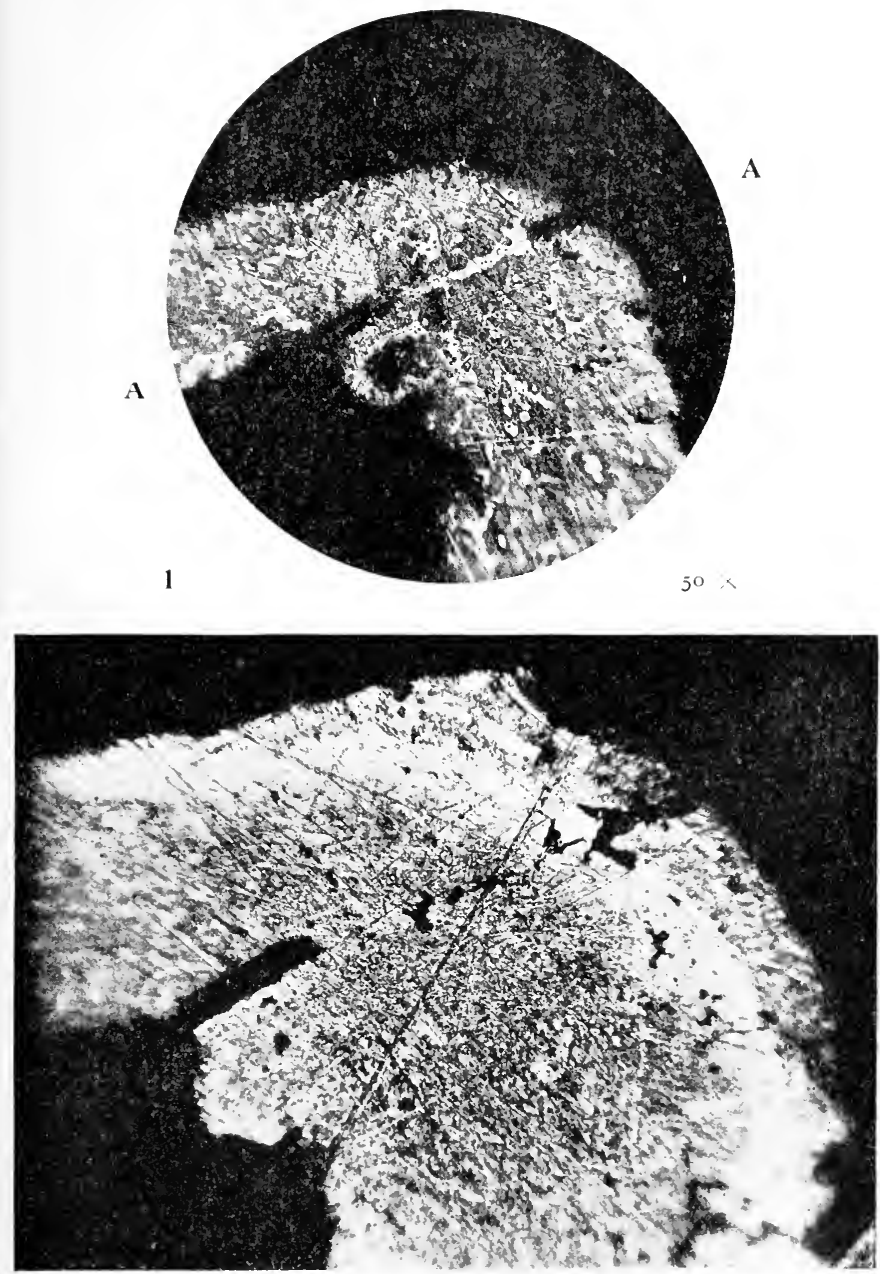

Iiig. 66, I $-66,2$. 
welded together by means of hammering or similar working at a high temperature - near the melting-point of the copper. The facts that point to this conclusion are: - the metallic continuity between the two parts, the above-mentioned wale, which was evidently formed by deformation in working the metal, the absence of soldering metal in the joint, and the absence of cuprous oxide eutectic (which would have resulted from welding by fusion without hammering). The necessary local heating of the joint was probably effected by means of a blowpipe. (The Peruvians, as known, use the blowpipe for heating purposes, as in smelting metals. ${ }^{1}$ ) Taking into consideration the well-known tendency that copper has to oxidize at a temperature approaching the melting-point, whereby welding is rendered considerably more difficult, it must be assumed that special steps were taken in the welding to protect the metal from the oxygen in the air, possibly embedment in charcoal, the admixture of a flux to keep the surfaces of the joint free from oxide, etc. 'The skill with which the work was carried out, is in any case astonishing, the more so since it appears to be generally considered impossible to weld copper in this manner so as to obtain a joint of any strength.

An analysis of the two halves of the rattle, carried out by Dr. G. KARL Almström at the laboratory of the town chemist in Gothenburg, I)r. J. E. Artén, has yielded the following result:

11pper half (sample weighing $0.4276 \mathrm{gr}$.) roo.20\% of copper lower " (.... ....... $0.5766 \ldots)$ Ioo.15 \% \%........

Both samples were exanined with negative results for gold, silver, tin, antimony, lead, arsenic, nickel, iron, and zink. The material in both halves is consequently exceedingly pure copper, which gives cause to presume that it was obtained by smelting native copper.

The following cases, which are of interest in comparisou with the one described above, are cited from the literature of the subject by Baron NondenskiöLD.

1) Siee I. 9 . 
Charles IV. MEad ${ }^{1}$ mentions two copper blowpipes in the American IItseum of Natural History. "These are $3 \mathrm{I}$ and 25 inches long respectively. They are both made of rather thick sheet copper and have at one end a tunnelshaped mouthpiece about $3^{1 / 2}$ inches in diameter at the rim. This part was made separately by bending the sheet copper into the desired form and then hammering or welding the edges firmly together. This mouthpiece was welded to the tube, which was made by bending the copper into the cylindrical form. In this case the edges are nicely brought together, but not welded."

No indication is given in the paper of how the presumed welding was carried out.

CrÉqui-MontFort \& RIVET ${ }^{2}$ ) describe objects, found in Columbia, of an alloy of gold, silver and copper with parts welded on. Here the welding had been performed by fusion, which was shown by small drops of metal near the welded joint. As these, like the welded joint itself, proved to have the same composition as the rest of the metal, we have here a case of autogenous welding, which probably did not offer any great difficulties in view of the composition of the alloy in question. The authors assume that the heating was done with the help of blowpipes.

Gothenburg, Sept. 24, I92I.

Iaboratory of the A.-B. Svenska Kullagerfabriken S. K. F. (Signed) Axel Hultgren.

1) Prehistorie Bronze in South America. Anthropological Papers of the American Museum of Natural History. New York, 19I5. P. 43.

2) Contribution a l'étude de l'archéologie et de la métallurgie colombiennes. Journal de la Société des Américanistes de Paris. Nouvelle série, Tome XI, r914-19ra. Paris rgra. P. 561 . 


\section{BIBLIOGRAPHY.}

Absandaux, H. (See de Créqui-Montfort).

(I) Ambrosetti, J. B. El bronce ell la region Calchaqui (Anales del Museo Nacional de Buenos Aires. T.XI. Buenos Aires 1904).

(2) - Exploraciones arqueológicas en la Pampa Grande. (Revista de la Universidad de Buenos Aires. 'T $\mathrm{I}$. Buenos Aires I906).

(3) - Exploraciones arqueológicas en la ciudad prehistórica de "La Paya". (Facultad de Filosofia y Letras. Publicaciones de la Sección Antropológica. No 3. 2 a Parte. Buenos Aires I9o8).

ANDrÊE, Richard. Die Metalle bei den Naturvölkern. I,eipzig I884.

(I) Bafssiter, Arthur. Altperuanische Metallgeräte. Berlin 1906.

(2) - Altperuanische Kunst. Berlin I902--I903.

Batboa, Miguei Cavelio. Histoire du Pérou. Paris is 40. ('Ternaux-Compans. Série II:4).

Bandelier, Adolf F. The islands of 'liticaca and Koati. New York igio.

Barba, Albaro Alonso. Arte de los metales. Madrid 1640.

Branzoni, Girolamo. History of the New World. I tondon I857. (Hakluyt Soc. Pub. No. 22).

Bertonio, Ludovico. Vocabulario de la I,engua Aymara. I,eipzig Isj9. (Ėdited by Platzman11).

Beuchat, $H$. Manuel d'archéologie américaine. Paris I 9 I 2. 
Brake, Jonn H. Notes on a collection from the ancient cemetery of the Bay of Chacota, Peru. (Reports of the Peabody Inseum. Vol II. Cambridge i 880).

(I) Boman, líric. Antiquités de la région andine de la République Argentine et dı l'ésert d'Atacama. I'aris 1908 .

(2) - Ias ruinas de Tinti. (Anales del Inuseo nacional de historia natural de Buenos Aires. 'T. XXYIII. Buenos Aires igi6.

Bruch, Carlos. Descripción de algumos sepulcros Calchayuis. (Revista del Museo de la Plata. 'T. XI. La Plata rgo2).

Buchwal, OtTo von. Notas etnológicas del Ecuador Occidental. (Boletin de la Sociedad Ecuatoriana de Estudios Históricos Americanos, Vol IV. Quito 1920).

Buel, (See Foote).

Cabrera, Geronmo Luis, de. Relacion en suma de la tierra y poblazones que don Geronimo Luis de Cabrera, gobernador de las provincias de los Juries, ha descubierto, donde va á poblar ell nombre de Su Magestad una cindad. (Relaciones geográficas de Indias. 'T. II. Madrid I885).

Casas, Bartolomé, dF las. De las antiguas gentes del Peru. (Colección de libros españoles raros ó curiosos. 'T. 21. Madrid I892).

Cieza de Leon, Pedro de. La crónica del Peru. (Biblioteca de Autores Españoles. T. XXXVI. Historiadores primitivos de Indias 'I. II. Madrid I862).

Cobo, Bernabí. Historia del Nuevo AIundo. T. IV. Sevilla $\mathrm{I} 895$.

Crégui-Montfort, G. de et Rivet, P. Contribution a l'étude de l'Archéologie et de la Métallurgie Colombiennes. (Avec la collaboration de H. AbSandarx, pour la partie métallurgique). (Extrait du Journal de la Societé des Américanistes de Paris. Nouvelle série, Tome XI, Igrt-igra. Paris r9I9). 
(I) Debenedetti, Salv. Excursión arqueológica á las ruinas de Kipón. (Facultad de Filosofia y Letras. Publicaciones de la Sección Antropológica. No. 4. Buenos Aires igo8).

(2) - Investigaciones arqueológicas en los valles preandinos de la provincia de San Juan. (De la Revista de la Universidad de Buenos Aires. T. XXXII. y' T. XXXIV Buenos Aires I9I7).

DORSEY, GEORGE A. Archæological Investigations on the Island of Ia Plata, Ecuador. (Field Columbian Museum. Publication 56. Anthropological Series. Vol. II. Chicago I90I).

EATON, GEORGE F. The collection of Osteological Material from Machu Picchu. (Memoirs of the Connecticut Academy of Arts and Sciences. New Haven, Connecticut I9I6).

ENock, Reginald. The Andes and the Amazon. Itondon I9I2.

Ewbank, Thomas. A description of the Indian antiquities brought from Chile and Peru by the U. S. Naval Astronomical Expedition. (The U. S. Naval Astronomical Expedition to the Sonthern Hemisphere during the years $\mathrm{I} 849-\mathrm{I} 85^{0}-\mathrm{I} 85 \mathrm{I}-\mathrm{I} 852$. Lieut. J. M. Gillis, superintendent, Vol II, Washington I855. Appendix E). Finderers Petrie, W. M. Tools and Weapons. London I9I7.

Foote, H. W. and Buel, W. H. The composition, structure, and hardness of some Peruvian bronze axes. (The American Journal of Science. Vol. XXXIV, New Haven I9I2).

(1) Forbes, David. On the Aymara Indians of Bolivia and Peru. (The journal of the Ethnological Society of London. Vol. 2, London I870).

(2) - Researches on the Mineralogy of South America. (Philosophical Magazine and Journal of Science. Vol. XXIX, XXX, London I865). 
Garcilasso de la Vega. Commentarios reales, que tratan del origen de los yncas. I,isboa 1609.

GibBon, Lardner. Exploration of the valley of the Amazon. (by $\mathrm{Wm}$. Lewis Herndon and Lardner Gibbon) Part II. Washington 1854 .

(iIglioli, E. H. Hafted copper implements from Peru. Man I904.

Goxzales Suarez, Fèderico. Historia general de la republica del Ecuador. Quito IS92.

Gow (The Journal of the Anthropological Institute. Vol. XXXVI, I906).

Hamy. Galerie Américaine du Musée d'Ethnographie du Trocadéro. Paris I $\$ 97$.

Heger, Franz. Zeremonial- oder Prunkaxt aus Bronze ans dem Gebiete der Diaguitas-Kultur des nordwestlichen Argentiniens. (Sonderabdruch aus Band XXXVI der Mitteilungen der Anthropologischen Gesellschaft in Wien). (Wien I9I6).

Holgrin, Diego Gonzalez. Vocabulario de la Lengua general de todo el Peru llamada lengua Qquichua... Ciudad de los Reyes r6o8.

(I) Holmes, IVimitam H. The use of Gold and other Metals among the ancient inhabitants of Chiriqui, Isthmus of Darien. (Smithsonian Institution. Washington $\mathrm{I} S 87$ ).

(2) - Handbook of Aboriginal American Antiquities. Part 1. Washington I9I9.

Huaman Poma. (See Pietscimann (2)).

JAckson, C. T. in: Proceedings of the Boston Society of Natural History. 'T. V. I $854-\mathrm{I} 8_{5} 6$.

(I) Jijón Y Chamaño, J. y I ARrea, Carlos, il. Un cementerio incasico en Quito. Quito I9I8.

(2) Jijón y CAAmaño, J. I os tincullpas y notas acerca de la metalurgia de los aborigines del Ecuador. (Boletin de la Academia Nacional de Historia. Vol. I, Quito I920). 
(.) - Artefactos prehistoricos del Guayas. Boletin de la sociedad Ecuatoriana de estudios historicos Americanos. Quito IgIS.

Joyce, 'Thomas A. Sonth American Archæology. London IQI 2 .

IARREA (S.ee JiJón Y CAAMLÑO).

I.ATCham, R. E. E1 Comercio precolombiano en Chile. santiago de Chile Igog.

I.EHMAN, WALTER. (Reriew of BoMaN (I). Zeitschrift für Ethnologie. Heft 3 11. +. I9IO).

Lemmann-Nitsche, Robert. Catálogo de las antigüedades de la Provincia de Jujuy, conservadas en el Inseo de I a Plata. (Revista del Misseo de Ia Plata. T. XI. La Plata I904).

Iac Curdy, George Grant. A Study of Chiriquian Antiquities (Memoirs of the Connecticut Academy of Arts and sciences. Vol. III. New Haven I9II).

Mathewson, C. H. A metallographic description of some

Ancient Peruvian Bronzes from Machu Picchu. (The American Journal of sicience. New Haven I9I5).

Mrad, Charles IT. Prehistoric Bronze in South America. (Anthropological papers of the American Museum of Natural History. Vol. XII, Part II. New York I9I Medina, Josk Toribio. Ios aborijenes de Chile. Santiḱ I 882.

MiddendorF, E. W. Wörterbuch des Runa simi oder der Keshua-Sprache. I,eipzig I89o.

(I) Montelius, Oscar. Die Chronologie der ältesten Bronzezeit in Nord-Deutschland und Skandinavien. (Archiv für Anthropologie. T. $25-26$, Braunschweig I $898-$ I 900$)$.

(2) - Minnen frán var forntid. Stockholm I9I7.

(3) - Kulturenwicklung Amerikas in Vergleich mit derjenigen der alten Welt (Compte rendu du Congrès international des Américanistes. Stockholm I894. Stockholm I897. 
Morlino, Firancisco P. Antropología y arqueología. (Anales de la Sociedad Cientifica Argentina. 'T. XII. Buenos Aires ISSI).

Montesinos, Finnando. Memorias antiguas historiales y politicas del Peru (Coleccion de libros espanoles raros ó curiosos. 'I'. I6). Madrid I $\$ 82$.

(i) Mortilitit, Adrien de. I,e Bronze dans l'Amérique du Sud avant l'arrivée des İuropéens. (Congrés préhistorique de France I re Session, Périgueux, I905. Paris I906).

(2) - L'age du Bronze en Chine. (Revue anthropologigile. 'T. XXIII. Paris I9I3).

(I) Nordenskiöld, Errand. Arkeologiska undersökningar i Perus och Bolivias gränstrakter I904-I905. (Kungl. Svenska Vetenskapsakademiens Handlingar. Bd. 42. Uppsala och Stockholm I906).

(2) - Urnengräber and Mounds im bolivianischen Flachlande. (Baessler-Archiv. Bd. III. Leipzig und Berlin I9I3).

(2 bis) - An ethno-geographical analysis of the material culture of two Indian Tribes in the Gran Chaco. (Comparative ethnographical studies. I. Göteborg I9I9).

1- The changes in the material culture of two Indian Tribes under the influence of new surroundings. (Comparative ethnographical studies. 2. Göteborg I920).

(4) - Die östliche Ausbreitung der Tiabuanaco-Kultur in Bolivien und ihr Verhältnis zur Aruakkultur in Mojos. (Zeitschrift für Ethnologie, Berlin I9I 7 ).

Oviedo y Valdes, Gonzalo Fernandez de. Historia general y natural de las Indias. Madrid I $_{5} 5 \mathrm{I}-55$.

Oyarzún, Aureirano. Hachas de cobre usadas por los Araucanos en la guerra de la Conquista de Chile. (Publicaciones del Museo de Etnología y Antropología de Chile. 'T. II. Santiago de Chile I920). 
Penck, Walter. Der Südrand der Puna de Atacama. (Des XXXVII Bandes der Abhandlungen der Mathematisch-Physischen Klasse der sächsischen Akademie der Wissenschaften. No I. Leipzig I920).

(i) Pietschmanx, Richard (See Sarmiento).

(2) - Some account of the illustrated chronicle by the Peruvian Indian, D. Felipe Huaman Poma de Ayala. (International Congress of Americanists, London I9I2. Part II. London. I9I3).

(I) Posnansky, Artuur. Das Treppenzeichen. Berlin I9I3.

(2) - Guía general ilustrada... de Tihuanacu. Ia Paz. I9I2.

Ramond, A. Minerales del Perr. Lima i $\$ 7 S$.

Reiss, W. und Striber, A. Das Todtenfeld von Ancon in Pert. Berlin I8So- I 887 .

Reraciones geográficas de Indias. Perú. T. I-IV. Madrid IS8I-I 897 .

(Ricardo, Antonio). Arte y vocabulario en la lengtua general del Peru llamado Quichua y en la lengua Espanola. En los Reyes, por Antonio Ricardo I $_{5} \$ 6$.

(I) Rivet P. et Verneau, R. Ethnograplie ancienne de 1'Équateur. (Mission du Service géographique de l'Armée pour la mesture d'un arc de méridien équatorial en Amérique du Sud. T. 6. Paris I9I2).

(2) - (See de Crêqui-MontFort).

ROSEN, ERIC vON. Enn förgången värld. Stockholm I9I9.

Samanos, Juan DE. Relacion de los primeros descubrimientos de Francisco Pizarro y Diego de Almagro, sacada del códice número $\operatorname{CXX}$ de la Biblioteca Imperial de Viena. (Coleccion de documentos inéditos para la liistoria de España. 'T. V. Madrid I $\left.S_{44}\right)$.

Sánchez Iíaz, P. Aber. Aleaciones. El bronce Calchaqui. Buenos Aires Igog. 
Sarniento de Gamboa, Padro. Geschichte des Inkareiches. (Abhandlungen der königlichen Gesellschaft der Wissenschaften zu Göttingen. Philologisch-Historische Klasse, Neue liolge, Band VI. No 4. Berlin I906). Edited by Ricmard Pietscimaxis.

SAlilfe, Marsmair H. The Antiquities of Manabi, Iicuador. T. I and T. II. New York I907, I9Io.

(I) SElER, Lidtard. Permanische Alterthümer. Berlin I 893 .

(2) - Bericht über die chemische und physikalische Untersuchung einer mexikanischen Kupferaxt. (Congr's International des Américanistes. XV. Session. 'Tonce II. Québec I907).

(I) Squifr, George Li. Pert. I,eipzig I883.

(2) - Aboriginal Ionuments of the State of New York. (Smithsonian Contributions to knowledge, 'T. II. Washington 1855$)$.

STC̈BEL (See Reiss).

Thomas, Saxcto. I éxicon ó V'ocabulario de la lengua general del Peru. Valladolid $5_{5} 60$.

Torres, Itis MARIA. I gos primitivos habitantes del delta del Paraná. Buenos Aires igi I.

T'schudi, J. J. vox. Die Kechua-Sprache. Wien I853.

(I) Uhle, Max. Kultur und Industrie südanerikanischer Völker. T. I. Berlin I 889 .

(2) - Pachacamac. Philadelphia Igo3.

(3) - Aus meinem Bericht über die Iirgebnisse meiner Reise nach südamerika I899-Igor. (Internationaler Amerikanisten-Kongress. Stuttgart igo4. 'T. 2. Stuttgart I906).

(4) - Las relaciones prehistóricas entre el Perú y la Argentina. (Actas del XVII Congreso Internacional de Americanistas. Buenos Aires I9I2).

(5) - The Nazca Pottery of ancient Peru. (Proceedings of the Davenport Academy of Sciences. Vol. XIII. Davenport I9I4). 
(6) - La arqueologia de Arica y Tacna. (Tirada aparte del Boletin de la Sociedad Ecuatoriana de Estudios históricos Americanos. Vol. III. Quito 19I9).

Urteaga, Horacio, H. E1 Fetichismo de los Yungas. (Boletin de la Sociedad Geográfica de Lima. 'T. XXXII. I ima I9I 7 ).

(I) Vernead (See Rivet).

(2) -- Tintinnabulum péruvien. (Bulletin de la Societé d'Anthropologie de Paris. Tome onzième. Paris I8S8). Wiener, Charles. Pérou et Bolivie. Paris isso.

Xerez, Franciscu de. Verdadera relacion de la Conquista del Perú. (Coleccion de libros que tratan de América raros ó curiosos. 'T. I. Madrid I $89 \mathrm{I}$ ). 


\section{JRRAT.}

I'age ori, $1 .+$ from the top read 1 ofur ${ }^{1}$.

$\Rightarrow$ i2s, fig. 53. f, not 5, analyses of tronzes from liticaca 1. Wre proved to contain 3 to +0 oi tin.

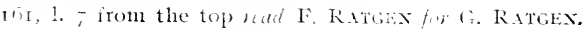




RETURN TO DESK FROM WHICH BORROWED

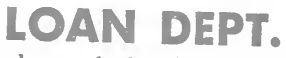

This book is due on the last date stamped below, or on the date to which renewed.

Renewed books are subject to immediate recall.
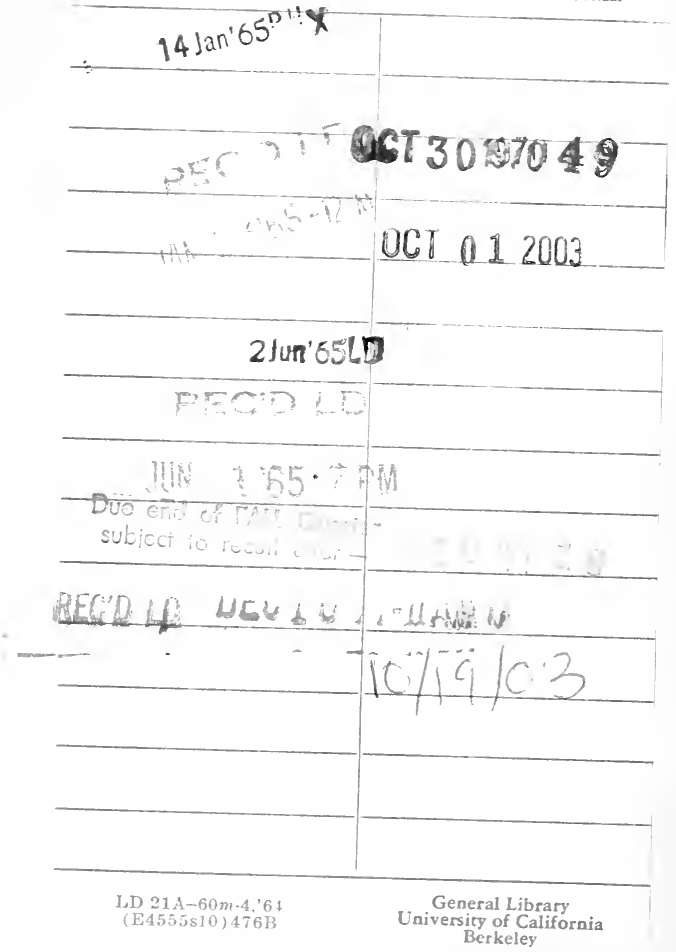


$$
\begin{aligned}
& 497248 \\
& F 2821 \\
& , j \\
& 04 \sqrt{8} \\
& \text { v. } 4
\end{aligned}
$$




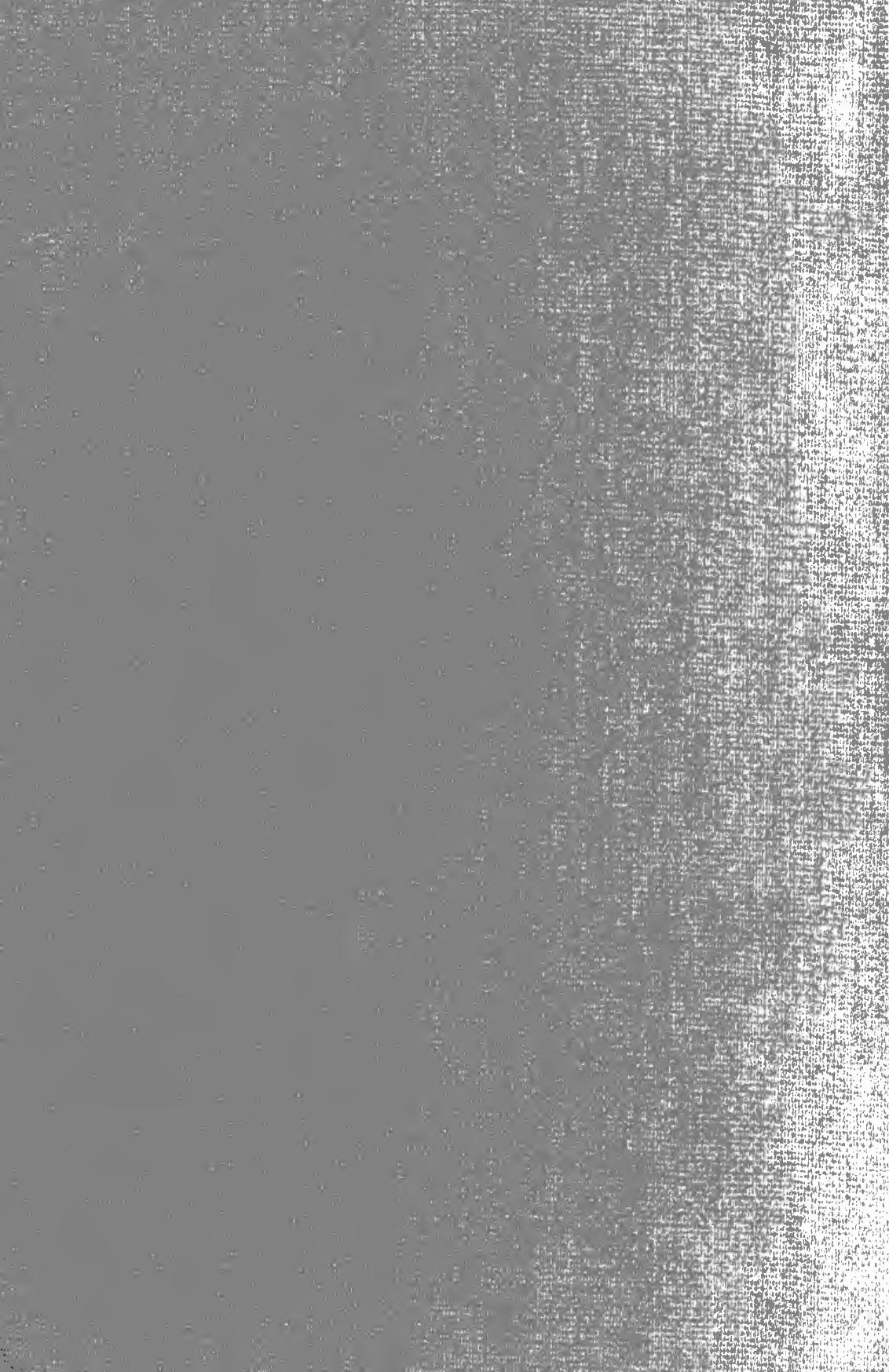

